\title{
CRESCIMENTO E ABSORÇÃO DE NUTRIENTES
}

\section{EM CINCO CULTIVARES DE FEIJOEIRO}

\author{
Phaseolus vulgaris $\mathbf{L}$.
}

EDUARDO ANTONIO BULISANI

Tese apresentada à
Supcola
Quperior de Agricultura "Luiz de
Queiroz", da Universidade de são
Paulo, para obtenção do título de
Doutor em Agronomia, Área de
concentração: Fitotecnia.




\section{CRESCIMENTO E ABSORÇĀO DE NUTRIENTES}

\section{EM CINCO CULTIVARES DE FEIJOEIRO}

\section{Phaseolus vulgaris L.}

EDUARDO ANTONIO BULISANI

Orientador: Prof.Dr. Antonio Luiz Fancelli

Tese apresentada à Escola Superior de Agricultura "Luiz de Queiroz", da Universidade de são Paulo, para obtenção do título de Doutor em Agronomia, Área de concentração: Fitotecnia.

\footnotetext{
Piracicaba

Estado de São Paulo - Brasil

Junho-1994
} 
Ficha catalográfica preparada pela Seção de Livros da Divisão de Biblioteca e Documentação - PCLQ/USP
Bulisani, Eduardo Antonio - Crescimento e absorção de nutrientes em cinco cultivares de feijoeiro Phaseolus vulgaris L. Piracicaba, 1994 .
150p. ilus.
Tese - ESALQ
Bibliografia.

1. Feijão - Crescimento 2. Feijão - Nutrição 3. Nutriente em feijão - Absorção I. Escola Superior de Agricultura Luiz de Queiroz, Piracicaba 


\section{CRESCIMENTO E ABSORÇÃO DE NUTRIENTES EM CINCO CULTIVARES DE FEIJOEIRO}

\section{Phaseolus vulgaris L.}

Aprovada em 22 de junho de 1994

Comissão Julgadora:

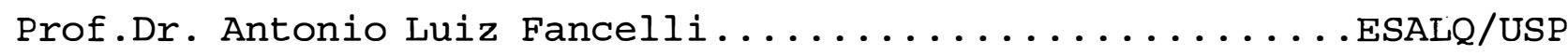

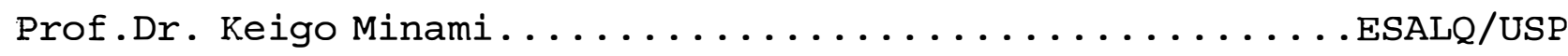
Dr. Hipólito Assunção Antonio Mascarenhas.............. IAC/SAA

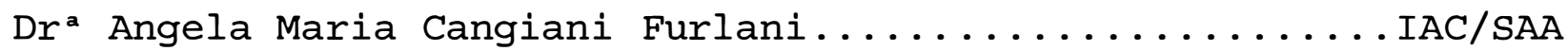

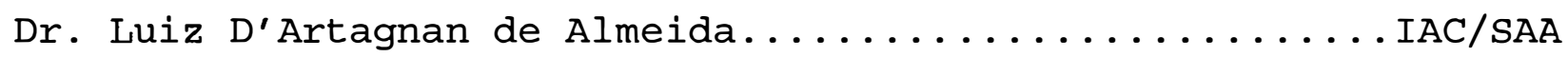

Prof. Dr. Antonio Luiz Fancelli Orientador 
Aos amores maiores

Maria das Dores e Ana Carolina

esposa e filha com quem a vida fazemos,

dedico

A quem a vida devemos

Domingos e Ilde, ofereço 


\section{Agradecimentos}

Estes agradecimentos não se restringem apenas aos que de maneira direta contribuíram para a execução deste treinamento e trabalho, queremos estender nossa gratidão e apreço aos :

Prof. Dr. Antonio Luiz Fancelli, conselheiro e orientador de nossa pós-graduação.

Prof. Dr. Keigo Minami, pelo apoio, incentivo e exemplo de dedicação.

Professores dos Departamentos de Agricultura e de Horticultura da Escola Superior de Agricultura "Luiz de Queiroz" pela formação técnico-científica e pela sempre viva amizade.

Pesquisador Científico Dr. Rúter Hiroce da seção de Fertilidade do Solo e Nutrição de Plantas do Instituto Agronômico pelo decidido apoio nas análises químicas das plantas de feijão.

Pesquisadores Shiro Miyasaka, Hipólito A.A. Mascarenhas, Luiz A.C. Lovadini, Romeu A.S. Kiihl, Luiz D'Artagnan de Almeida, Manoel A.C. de Miranda e Nelson R. Braga, da Seção de Leguminosas do Instituto Agronômico, de e com quem muito aprendemos de agricultura.

Pesquisador Armando Conagin pela amizade e lições de estatística e aos engenheiros agrônomos Alaor Menegario e Antonio Jorge Roston do DEXTRU/CATI pelo acompanhamento nas lides da produção e da extensão rural.

Servidoras do Instituto Agronômico Adelaide F. Lima, Maria Beatriz C.C. de Menezes e Vera Lucia P. de Oliveira, pela tradução do texto e todas as correções.

Instituto Agronômico do Estado de São Paulo (IAC) da Coordenadoria da Pesquisa Agropecuária da Secretaria de Agricultura e Abastecimento (CPA/SAA) pela oportunidade do treinamento e à Coordenação de Aperfeiçoamento do Pessoal de Nível Superior (CAPES) pela bolsa de pósgraduação. 
CONTEÚDO

PÁG.

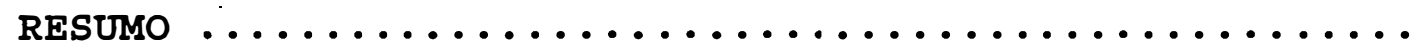

1. Introdução .............................

2. Revisão de Literatura .......................

2.1 Crescimento .........................

2.2 Absorção de Nutrientes ...................

3. Material e Métodos .........................

4. Resultados e Discussão

4.1 Condições Ambientais ....................

4.2 Crescimento das Plantas ..................

4.3 Absorção de Nutrientes ..................

5. Conclusões ............................

6. Literatura Citada ....................... 


\section{IISTA DE QUADROS}

\section{QUADRO}

PÁG.

1 - Produção de matéria seca das flores e vagens do

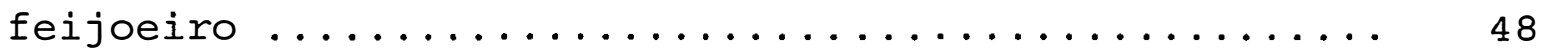

2 - Número médio de vagens e sementes $\ldots \ldots \ldots \ldots \ldots \ldots . \ldots 48$

3 - Produção de matéria seca em kg/ha pelas diversas par-

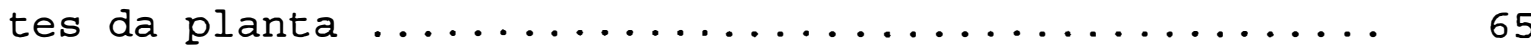

4 - Índices fisiológicos médios determinados nas plantas do feijoeiro na última colheita ............... 65

5 - Teor de nitrogênio nas raízes do feijoeiro .......... 80

6 - Teor de fósforo nas raízes do feijoeiro ............ 80

7 - Teor de potássio nas raízes do feijoeiro ............ 84

8 - Teor de cálcio nas raízes do feijoeiro ............. 84

9 - Teor de magnésio nas raízes do feijoeiro ........... 87

10 - Teor de nitrogênio nas hastes do feijoeiro .......... 87

11 - Teor de fósforo nas hastes do feijoeiro ............ 91

12 - Teor de potássio nas hastes do feijoeiro ........... 91

13 - Teor de cálcio nas hastes do feijoeiro ............. 96

14 - Teor de magnésio nas hastes do feijoeiro ........... 96

15 - Teor de nitrogênio nas folhas do feijoeiro .......... 100

16 - Teor de fósforo nas folhas do feijoeiro ............ 100

17 - Teor de potássio nas folhas do feijoeiro ........... 103

18 - Teor de cálcio nas folhas do feijoeiro ............. 103 
19 - Teor de magnésio nas folhas do feijoeiro......... 106

20 - Teor de nitrogênio, fósforo, potássio, cálcio e magnésio nas flores do feijoeiro ................. 106

21 - Quantidade de nutrientes acumulado nas flores do

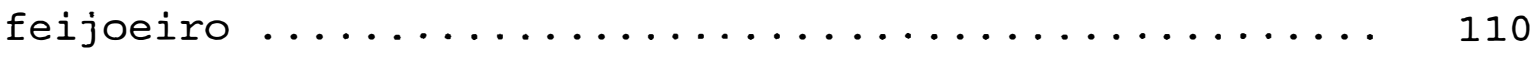

22 - Teor e quantidade de nitrogênio nas vagens do fei-

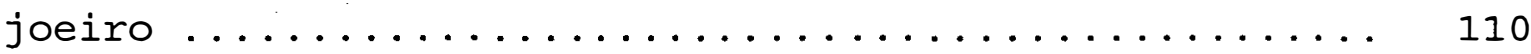

23 - Teor e quantidade de fósforo nas vagens do feijoeiro.. 111

24 - Teor e quantidade de potássio nas vagens do feijoeiro. 111

25 - Teor e quantidade de cálcio nas vagens do feijoeiro .. 114

26 - Teor e quantidade de magnésio nas vagens do feijoeiro. 114

27 - Teor e quantidade de nitrogênio nas sementes do

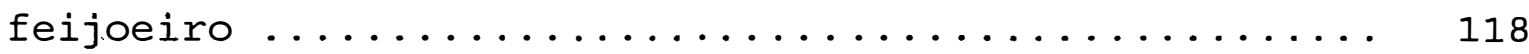

28 - Teor e quantidade de fósforo nas sementes do fei-

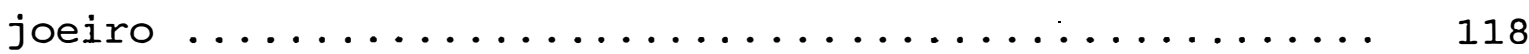

29 - Teor e quantidade de potássio nas sementes do fei-

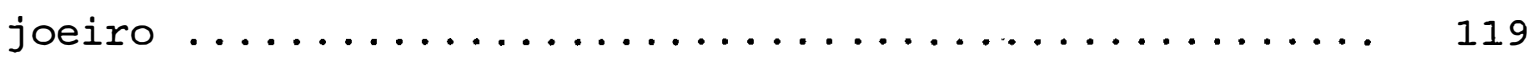

30 - Teor e quantidade de cálcio nas sementes do feijoeiro. 119

31 - Teor e quantidade de magnésio nas sementes do fei-

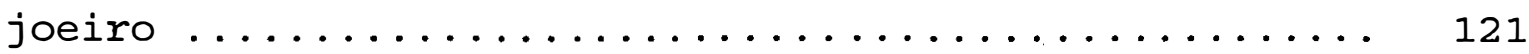

32 - Quantidade total de nitrogênio absorvida pelo feijoeiro nas diversas idades das plantas............. 
33 - Quantidade total de fósforo absorvida pelo feijoeiro

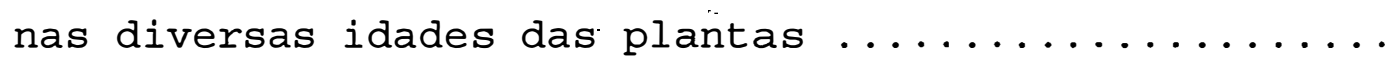

34 - Quantidade total de potássio absorvida pelo feijoeiro

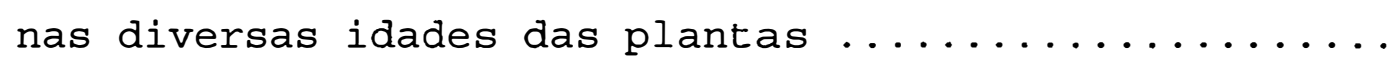

35 - Quantidade total de cálcio absorvida pelo feijoeiro

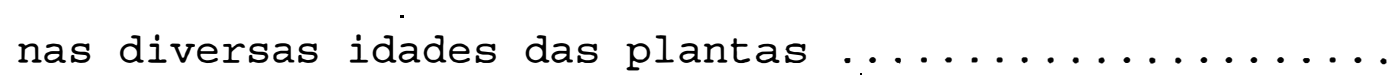

36 - Quantidade total de magnésio absorvida pelo feijoeiro

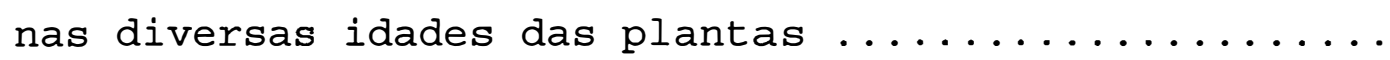

37 - Quantidade máxima de nutrientes absorvida pelos culti-

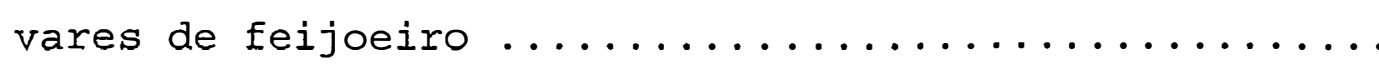

38 - Acúmulo total de nutrientes pela planta do feijoeiro

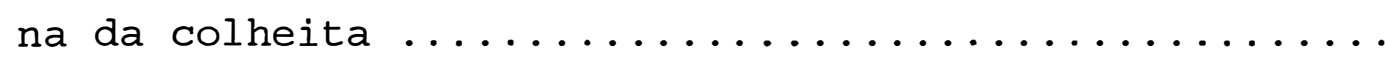

39 - Extração de nutrientes pelas sementes do feijoeiro ...

40 - Relação entre a quantidade máxima de nutrientes absor-

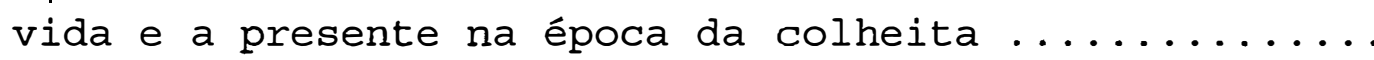

41 - Relação entre a quantidade de nutrientes presentés na época da colheita e a exportada pelas sementes ......

42 - Relação entre a quantidade máxima de nutrientes absorvida e a exportada pelas sementes ............ 


\section{LISTA DE FIGURAS}

\section{FIGURA}

PÁG.

1 - Temperatura máxima, média e mínima ............. 40

2 - Umidade relativa do ar máxima, média e mínima ...... 41

3 - Produção de matéria seca das raízes .............. 43

4 - Produção de matéria seca das hastes .............. 45

5 - Produção de matéria seca das folhas ............. 46

6 - Produção de matéria seca das partes reprodutivas .... 50

7 - Produção total de matéria seca ................ 52

8 - Altura média das plantas ................... 53

9 - Número de folhas do feijoeiro ................. 55

10 - Área foliar do feijoeiro ................... 56

11 - Área média das folhas do feijoeiro ............. 58

12 - Área foliar específica ..................... 60

13 - Massa foliar específica .................... 61

14 - Número de vagens e produção de massa seca ..........63

15 - Distribuição da matéria seca nos diversos órgãos do feijoeiro cultivar Bico de Ouro ................ 68

16 - Distribuição da matéria seca nos diversos órgãos do

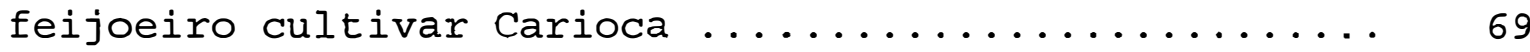

17 - Distribuição da matéria seca nos diversos órgãos' do feijoeiro cultivar Goiano Precoce ............... 70

18 - Distribuição da matéria seca nos diversos órgãos do feijoeiro cultivar Rico $23 \ldots \ldots \ldots \ldots \ldots \ldots$ 
FIGURA

PÁG.

19 - Distribuição da matéria seca nos diversos órgãos do feijoeiro cultivar Rosinha $G 2 \ldots \ldots \ldots \ldots \ldots$

20 - Distribuição porcentual da matéria seca nos diversos órgãos do feijoeiro cultivar Bico de ouro ..........

21 - Distribuição porcentual da matéria seca nos diversos

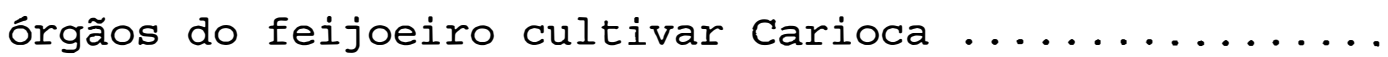

22 - Distribuição porcentual da matéria seca nos diversos órgãos do feijoeiro cultivar Goiano Precoce .........

23 - Distribuição porcentual da matéria seca nos diversos órgãos do feijoeiro cultivar Rico $23 \ldots \ldots \ldots \ldots \ldots$

24 - Distribuição porcentual da matéria seca nos diversos órgãos do feijoeiro cultivar Rosinha $\mathrm{G} 2 \ldots \ldots \ldots \ldots$

25 - Acúmulo de nitrogênio nas raízes do feijoeiro .......

26 - Acúmulo de fósforo nas raízes do feijoeiro .........

27 - Acúmulo de potássio nas raízes do feijoeiro .........

28 - Acúmulo de cálcio nas raízes do feijoeiro ..........

29 - Acúmulo de magnésio nas raízés do feijoeiro ........

30 - Acúmulo de nitrogênio nas hastes do feijoeiro ...... 90

31 - Acúmulo de fósforo nas hastes do feijoeiro ........ 92

32 - Acúmulo de potássio nas hastes do feijoeiro ........ 94

33 - Acúmulo de cálcio nas hastes do feijoeiro ......... 95

34 - Acúmulo de magnésio nas hastes do feijoeiro ........ 98

35 - Acúmulo de nitrogênio nas folhas do feijoeiro ....... 99

36 - Acúmulo de fósforo nas folhas do feijoeiro ......... 101 
37 - Acúmulo de potássio nas folhas do feijoeiro ......... 104

38 - Acúmulo de cálcio nas folhas do feijoeiro .......... 105

39 - Acúmulo de magnésio nas folhas do feijoeiro ........ 109

40 - Acúmulo de nitrogênio nas partes reprodutivas ....... 112

41 - Acúmulo de fósforo nas partes reprodutivas ......... 113

42 - Acúmulo de potássio nas partes reprodutivas ........ 115

43 - Acúmulo de cálcio nas partes reprodutivas ......... 116

44 - Acúmulo de magnésio nas partes reprodutivas ........ 117 


\title{
CRESCIMENTO E ABSORÇÃO DE NUTRIENTES EM CINCO CULTIVARES DE FEIJOEIRO (Phaseolus vulgaris L.)
}

\author{
Autor: MSc. Eduardo Antonio Bulisani \\ Orientador: Prof. Dr. Antonio Luiz Fancelli
}

\section{RESUMO}

Foi conduzido em casa de vegetação em vasos com $12 \mathrm{~kg}$ de terra adubada, um experimento para avaliar o crescimento e a absörção de $\mathrm{N}, \mathrm{P}, \mathrm{K}, \mathrm{Ca}$ e Mg nos cultivares de feijoeiro (Phaseolus vulgaris L.), Bico de Ouro, Carioca, Goiano Precoce, Rico 23 e Rosinha G2.

De modo geral as raízes reduziram seu crescimento antes que as demais partes, ao redor do $40^{\circ}$ dia após a emergência, seguida depois pelas hastes e posteriormente pelas folhas. Logo após o florescimento as hastes atuaram como armazenadores intermediários de fotossintetizados. As sementes mostraram um intenso acúmulo de matéria seca nos últimos 20 dias do ciclo. Em um intervalo de dez dias, plantas de ciclo total semelhante, não se apresentaram na mesma fase fisiológica, assim é que, Bico de ouro floresceu compactamente e acumulou matéria seca nas sementes antes 
dos demais, já Rico 23 mostrou comportamento inverso com alta taxa de acúmulo de matéria no último decêndio. Os componentes da produção como número de vagens/vaso, número de sementes/vagem e massa da semente, mostraram grande variação entre cultivares, mas só eles não foram suficientes para explicar as diferenças observadas na produção de grãos, também o índice de colheita, que foi de 50\% em Goiano Precoce a $66 \%$ em Bico de Ouro é fator relevante na comparação de materiais de desenvolvimento semelhante.

A produção de grãos estimada em kg/ha foi de 2.807 para Carioca, 2.690 para Bico de Ouro, 2.615 para Rico 23, 2.436 para Rosinha G2 e 1.090 para Goiano Precoce, sendo que só este último diferiu significativamente dos demais.

Nitrogênio, potássio, cálcio, magnésio e fósforo foi a ordem de grandeza decrescente de acúmulo de nutrientes sendo matéria seca produzida a grande determinante da quantidade de nutrientes absorvida. Entre 50 e $80 \%$ do nitrogênio e 66 e $86 \%$ do fósforo absorvidos são exportados pelas sementes. Os valores para potássio variaram entre 26 e 50\%, para magnésio entre 28 e $38 \%$ e entre 9 e 17\% para cálcio, dependendo do cultivar avaliado.

Para todos os nutrientes, da mesma forma que já tinha sido observada para o índice de colheita, Goiano Precoce foi - cultivar que apresentou os mais baixos índices entre quantidade 
exportada e quantidade absorvida, mostrando baixa eficiência de translocação tanto de matéria seca quanto de nutrientes.

Termos de indexação: Crescimento, absorção e exportação de nutrientes, cultivares de feijão. 
GROWTH AND NUTRIENT UPTARE IN

\section{FIVE DRY BEAN (Phaseolus vulgaris L.) CULTIVARS}

Author: MSc.Eduardo Antonio Bulisani

Adviser: Prof. Dr. Antonio Luiz Fancelli

\section{SUMMARY}

From june to september, it was carried out an experiment under glasshouse condition in pots with soil in Campinas, state of são Paulo, Brazil, with the aim of evaluating the growth and N, P, K, Ca e Mg uptake in 'Bico de Ouro', 'Carioca', 'Goiano Precoce', 'Rico 23' and 'Rosinha G2' dry bean cultivars (Phaseolus vulgaris L.). At ten day intervals plants were harvested, separated into roots, shoots, leaves, flowers, pods and seeds, evaluated for dry matter production, other growth parameters and nutrient content.

Roots had their growth reduced before other plant parts, around the $40^{\circ}$ day after germination, followed by shoots and leaves. Soon after flowering shoots worked as intermediate sink for the carbohydrates. Seeds showed a fast increase of dry matter accumulation in the last twenty days of life span. At a ten day interval, cultivars of similar cycle, were not in the same 
physiological growth stadium, so comparisons among them have to consider this fact. Cultivar 'Bico de Ouro' flowered in a few days and accumulated seed dry matter earlier than others with the same cycle, meanwhile 'Rico 23' showed higher accumulation in the last ten days. Yield components as pods/pot, seeds/pod and seed weight showed large variation among tested cultivars but they alone were not enough to explain grain yield differences. Harvest indexes, which varied from $50 \%$ in 'Goiano Precoce' to $66 \%$ in 'Bico de Ouro', also should be taken into account in comparisons of similar growth habit materials.

The estimated grain yield in $\mathrm{kg} / \mathrm{ha}$ was of 2,807 for 'Carioca', 2,690 for 'Bico de Ouro', 2,615 for 'Rico 23', 2,436 for 'Rosinha G2' and 1,090 for 'Goiano Precoce'. Only this last one yielded significantly less than the others.

Nitrogen, potassium, calcium, magnesium and phosphorus was the decreasing order of nutrient uptake. Within plant parts nutrient content was quite similar among the bean cultivars being dry matter production the determinant factor in nutrient accumulation.

About 50 to $80 \%$ of the nitrogen and from 66 to $86 \%$ of the absorbed phosphorus were exported by the seeds. Values for potassium varied from 26 to 50\%; for magnesium, from 28 to $38 \%$ and from 9 to 17\% for calcium depending upon cultivar. It should be noted the high variation among cultivars, showing wide differences 
in relation to each nutrient. As it was observed for harvest index, nutrient uptake in 'Goiano Precoce' showed the lowest values for the relation nutrient in the seed to nutrient in the plant, thus showing lower efficiency in translocation for both dry matter and nutrients.

Index terms: Plant growth, nutrient uptake and export, dry bean cultivars, harvest index. 


\section{INTRODUÇÃO}

A cultura do feijoeiro apresenta importância para a população brasileira sendo tradicional seu cultivo desde os tempos da colonização. Atualmente esta importância pode ser medida tanto pelo valor econômico de sua exploração quanto pela constância de sua presença no hábito alimentar dos brasileiros.

No entanto, até final da década de 60 , tanto pelo caráter subsidiário de sua produção, normalmente cultivado em consórcio, como pelo plantio em regiões recém desbravadas, era encarado como atividade econômica secundária, não havendo grande interesse pela sua melhoria tanto por parte dos agricultorés em obter elevada produtividade, quanto pela pesquisa em promover estudos básicos detalhados das características da planta, visando o conhecimento das possibilidades produtivas da espécie.

A partir dos anos 70, em virtude da pressão da demanda causada pelo êxodo rural e concentração da população em zonas urbanas, pela maior tecnificação de outras explorações agrícolas, impossibilitando o plantio em consórcio e pelo 
incremento da exploração do feijoeiro como cultura principal, notadamente em algumas áreas de características climáticas mais favoráveis a esta leguminosa, intensificaram-se os estudos com vistas a um melhor conhecimento da planta feijão.

Deve-se ressaltar o impressionante avanço tecnológico e econômico a que foi submetido o feijoeiro desde o início dos anos 80 , com o desenvolvimento do cultivo irrigado efetivado no período de inverno, principalmente nas latitudes menores que $22^{\circ} \mathrm{S}$. A expansão deste cultivo possibilitou desde a produção em grande escala de sementes com elevado grau de sanidade, até a quebra da predominância de duas safras anuais, promovendo um fluxo mais contínuo de feijão novo ao mercado.

Sabe-se que a produção de uma cultura é resultante de uma série de fatores tais como a própria planta ou cultivar, solo, fertilização, clima, práticas culturais, pragas e moléstias, etc. Para o feijoeiro, tendo-se em vista a baixa produtividade média brasileira, pode-se assumir que provavelmente residem nos métodos de cultivo e no clima os principais fatores determinantes der daquela baixa produtividade.

Revisões de MALAVOLTA (1972) e de ROSOLEM (1987) indicam ser o consumo de adubos para o feijoeiro muito pequeno, acarretando, juntamente com as condições climáticas adversas, baixo rendimento. MIYASAKA e ALMEIDA (1968) apontam as condições de clima e de solo provavelmente como as de maior importância a contornar, visando elevar a produtividade do feijoeiro. ALVIM e ALVIM (1969) e BRANDES (1971) comentam ser o feijoeiro uma planta de baixa 
eficiência fotossintética, apresentando índices de área foliar inferiores a 4 .

Este trabalho pretende fornecer mais subsídios para o conhecimento do feijoeiro, estabelecendo relações de crescimento e de absorção de nutrientes entre cinco cultivares comuns desta espécie, em aditamento a algumas pesquisas já efetuadas, além de ressaltar as influências do ambiente sobre essas medidas. 


\section{REVISÃO DA LITERATURA}

Considerando que o ambiente determina, com grande intensidade, o desenvolvimento do feijoeiro, afetando não só o crescimento físico de seus componentes como também sua composição química, procurou-se dividir a revisão de literatura em duas partes: crescimento e absorção de nutrientes; enfatizando, sobre estes parâmetros as influências da umidade e da temperatura. Nas condições brasileiras, muitos artigos científicos ou de divulgação técnica apontam ser o feijoeiro uma planta de extrema sensibilidade às condições climáticas, no entanto esta afirmativa baseia-se mais na vivência e observações pessoais do que em investigação científica. Citações bem fundamentadas para nossas condições são as devidas a BRANDES (1971), MIYASAKA et al. (1966, 1968), MAGALHÃES et al. (1971), LOPES et al. (1983) e ARAUJO (1983). 


\subsection{Crescimento}

GALLO e MIYASAKA (1961) estudando a composição química do feijoeiro, cultivar Chumbinho Opaco, em solo adubado ou não, apontaram um crescimento gradativo na produção de matéria seca com maior intensidade no período de 53 a 65 dias de idade das plantas, quando as mesmas eram desenvolvidas em ausência de adubação. Já no solo adubado este período foi antecipado para 33 a 44 dias. Foi apontada ainda uma redistribuição dos fotossintetizados das partes vegetativas para as vagens e sementes, da ordem de $601 \mathrm{~kg} / \mathrm{ha}$ no período entre 44 e 65 dias de idade das plantas, quando adubadas. Constataram ainda que na maturação há duas vezes mais matéria seca que no florescimento.

HAAG et al. (1967) observaram que o feijoeiro, até os 20 dias de idade, apresentou apenas 5\% de sua massa final, a partir do $30^{\circ}$ dia houve um crescimento brusco, sendo atingidos os máximos valores ao redor do $50^{\circ}$ dia de idade. Deste ponto em diante houve um decréscimo na matéria verde devido ao secamento das plantas e queda das folhas. Determinaram ainda a percentagem de matéria seca na planta em relação à verde, encontrando que ela se mantém aproximadamente constante até o $50^{\circ}$ dia, apresentando um crescimento sensível a partir desta idade como resultado da maturação dos grãos. Apontaram também que na maturação há o quádruplo de matéria seca em relação ao florescimento, enquanto que GALLO e MIYASAKA (1961) indicaram uma relação dupla. 
COBRA NETTO (1967), em condições de campo, apontou um crescimento contínuo da matéria fresca até $056^{\circ}$ dia após a semeadura, havendo um decréscimo desta data em diante, citando como causa a queda das folhas e secamento das plantas. A curva da produção de matéria seca foi semelhante à da matéria fresca, apresentando um máximo no $56^{\circ}$ dia, uma ligeira diminuição até $066^{\circ}$ devido queda intensa das folhas, seguida de leve aumento causado sobretudo pela maior produção de vagens. Quanto às partes da planta, foi determinada uma produção máxima de matéria seca de rá́zes no $56^{\circ}$ dia havendo uma diminuição a seguir. A produção de matéria seca dos caules e folhas apresentou a mesma tendência, já a matéria fresca das folhas atingiu seu maior valor no $46^{\circ}$ dia de idade das plantas. A matéria fresca das vagens elevou-se acentuadamente entre 056 e $\circ 66^{\circ}$ dia após a semeadura e diminuiu no $77^{\circ}$, quando da colheita, devido à perda de umidade, no entanto a produção de matéria seca de vagens cresceu continuadamente do $56^{\circ}$ dia até o final do ciclo.

Em ensaio conduzido em solução nutritiva, COBRA NETO (1967) determinou efeitos redutores intensos na produção de matéria seca de raízes, com a omissão de magnésio, fósforo, nitrogênio e cálcio. Redução menos intensa foi observada para a omissão de potássio e enxôfre, sendo que na falta deste último nutriente a produção de raízes foi semelhante à do tratamento completo. A produção de matéria seca dos caules não foi afetada pela omissão de potássio e enxôfre, no entanto a falta de magnésio, cálcio, fósforo e nitrogênio diminuiu o desenvolvimento dos caules. 
A omissão de enxôfre, magnésio e potássio não afetou significativamente a produção de matéria seca das folhas, no entanto a falta de cálcio, fósforo e nitrogênio a diminuiu.

BRANDES (1971), em estudo sobre análise de crescimento do feijoeiro, conduzido sob condições de campo, mostrou que a produção de matéria seca foi altamente dependente das condições climáticas, sendo que no período "das águas" a mesma foi duas vezes superior à "da seca"; que o crescimento individual das plantas é inversamente proporcional às densidades de plantio, o que demonstra a importância do número de plantas por unidade de área e a capacidade que o feijoeiro apresenta de compensar, dentro de certos limites, pelo crescimento individual, a maior ou menor densidade de plantio. Tanto folhas como raízes apresentaram um máximo de crescimento por volta dos 40 a 50 dias de idade das plantas, indicando ainda que as folhas participaram percentualmente com valores elevados nas primeiras fases do ciclo, sendo mínima sua contribuição na maturação. Percentualmente a matéria seca dos caules participou diferentemente em relação às raízes e folhas, apresentando um máximo em torno dos 50 dias para o plantio "da seca" e 60 para os "das águas" sugerindo que os caules são por algum tempo depósitos dos produtos fotossintetizados, da mesma forma que as vagens o serão mais tarde de maneira definitiva e acentuada. Os valores máximos de produção de matéria seca se deram aos 60 e 50 dias após a emergência, para os plantios "das águas" e "da seca" respectivamente. 
MALAVOLTA (1972), analisando quase duas centenas de ensaios de adubação do feijoeiro efetuados nas mais diversas condições brasileiras, verificou que os efeitos de local e época de plantio na maioria das vezes são superiores aos dos tratamentos de adubação devido à grande variação das respostas aos fertilizantes aplicados.

WALLACE e MUNGER (1965) estudando as bases fisiológicas dos diferentes rendimentos, por meio da análise de crescimento em seis cultivares de feijão apontaram que os de maior produtividade apresentaram maior área foliar e maior razão de área foliar. Em um grupo de cultivares a taxa de crescimento relativo e a taxa de crescimento das folhas foram acompanhadas por uma razão de área foliar mais alta, sugerindo ser este fator o principal responsável por estas diferenças. A razão de área foliar atingiu valores máximos para todos os cultivares antes dos 30 dias de idade $\left(1,6\right.$ a $\left.1,8 \mathrm{dm}^{2} / \mathrm{g}\right)$.

WALLACE e MUNGER (1966), obtiveram Índices de colheita variando de 53 a $67 \%$, não sendo porém estes índices correlacionados com o hábito de crescimento e nem com o período de maturação. Os dados apresentados indicaram diferenças entre cultivares, provavelmente genéticas, para produtividade biológica, econômica e para índice de colheita. Área foliar, razão da área foliar, taxa de crescimento relativo e taxa de crescimento relativo das folhas apresentaram variações entre os cultivares estudados sendo que a área foliar e a razão de área foliar eram associadas à maior produtividade em alguns cultivares e não em outros. Da mesma 
maneira que para índices fisiológicos, a comparação dos componentes da produção: número de vagens, número de sementes por vagem e massa média das sementes apresentaram diferenças entre cultivares. Comentaram ainda que o grande número de fatores fisiológicos controlados geneticamente, mais a ampla gama de influência do ambiente, mais a tendência de correlação inversa entre os componentes da produção, torna extremamente diffícil a determinação das bases fisiológicas para diferenças genéticas na produção econômica .

ALVIM e ALVIM (1969) determinaram a eficiência fotossintética do milho e do feijão, quando semeados em diferentes densidades em condições de clima tropical. A taxa de produção de matéria seca total aumentou em proporção à densidade de semeadura, atingindo um valor máximo de $57,7 \mathrm{~g} / \mathrm{m}^{2} / \mathrm{dia}$ com milho, na densidade de $100 \mathrm{plantas} / \mathrm{m}^{2}$. Este dado corresponde a uma eficiência de conversão da energia luminosa de $10,5 \%$, durante o primeiro mês de cultivo. Em todas as densidades, o feijão apresentou uma eficiência fotossintética $1 / 3$ menor que a do milho, variando de 0,6 a 2,9\% durante os primeiros 27 dias. O índice de área foliar variou de 1,4 a 7,6 na cultura exclusiva (solteira).

MAGALHÃES et al. (1971) estudaram o efeito da adubação orgânica e mineral, sobre o crescimento do feijoeiro cultivar Carioca, sendo os máximos valores da taxa assimilatória líquida em relação à área e eficiência de conversão da energia solar observados no período entre 25 a 35 dias após a emergência. Observaram também índices de área foliar bastante elevados no 
período do florescimento, quando havia incorporação de matéria orgânica no solo, causando auto sombreamento e diminuição do crescimento em fases posteriores. Plantas de feijoeiro, adubadas ou não, apresentaram crescimento menos intenso mas constante até além do $50^{\circ}$ dia após a emergência. Apesar de grandes aumentos na taxa de crescimento relativo, taxa assimilatória líquida e eficiência da conversão de energia solar, devido à incorporação de matéria orgânica, foram observados pequenos aumentos na produção de grãos .

MONTOJOS e MAGALHÃES (1971) apontaram, que alta intensidade de radiação solar promoveu aumento na taxa de crescimento e maior produção de grãos devido ao seu efeito no aumento do índice de área foliar. O fracionamento da adubação nitrogenada durante o período vegetativo induziu modificações nos parâmetros de crescimento, que foram mais intensas sob condições de baixa luminosidade. Maiores produções de sementes foram obtidas quando a aplicação do nitrogênio foi parcelada nos 21 primeiros dias do ciclo; este procedimento atrasou a senescência das folhas e aumentou a capacidade fotossintética devido a aumento na duração da área foliar. Menor intensidade de luz induziu menor acúmulo de matéria seca e tendência de diminuição do índice de área foliar após o.florescimento, em contraste aos valores observados sob condições de alta luminosidade, onde o índice de área. foliar cresceu até os 50 dias após emergência. Comentaram ser o feijoeiro altamente sensível à quantidade de radiação recebida e sua taxa de crescimento é muito influenciada pela aplicação de fertilizantes. 
LOPES (1988), baseado em dados de LOPES et al. (1983), de BROWER (1962) e de ANTONIW e SPRENT (1978), discutiu que a redução na radiação solar aumentou a razão parte aérea/raiz por retardar o crescimento das raízes em virtude da redução no fornecimento de carboidratos para estas partes. Apontou ainda que a taxa de acúmulo de matéria seca é seqüencial, modificando-se conforme o estádio de crescimento da planta. No início, folhas e raízes são drenos preferenciais, por certo período os caules assumem relevância, e, a partir do florescimento, com aparecimento das vagens estas passam a ser os drenos preferenciais, comentou ainda que o sombreamento não altera esta ordem. Segundo ARAUJO (1983) plantas do cultivar Ricobaio 1014 submetidas a diversos sistemas de consórcio, portanto sob diferentes regimes de fluxo luminoso, mostraram maior expansão foliar, evidenciando adaptação do feijoeiro de modo a tentar captar com maior eficiência a luz disponível, esta mesma tendência foi observada por LOPES et al. (1982) em cultivo de feijoeiro artificialmente sombreado.

MAGALHÃES e MONTOJOS (1971) apontaram que a radiação solar provocou apreciáveis efeitos sobre características de crescimento e produção de grãos dos cultivares Carioca e Pintado. Maior radiação solar provocou elevado crescimento vegetativo e produção em ambos; o inverso foi observado para regime de baixa radiação. Devido a maior eficiência fotossintética, 'Carioca' produziu mais grãos sob ambos os regimes de radiação solar, os autores sugeriram que este cultivar é mais eficiente que 'Pintado', devido a maior produtividade biológica sob alta 
intensidade de luz. Esta característica fica evidenciada considerando-se a relação de conversão de energia com índices de área foliar, que mostrou maiores valores para o cultivar Carioca após o florescimento, quando as folhas estão mais envolvidas no suprimento de reservas para os grãos.

IZHAR e WALLACE (1967b) medindo a eficiência fotossintética em cultivares de feijão, encontraram diferenças entre eles, sendo alguns superiores a outros. A absorção de $\mathrm{CO}_{2}$ era praticamente a mesma nas intensidades luminosas pesquisadas, e determinaram que as bases para as diferenças varietais residem nas reações fotossintéticas que se processam no escuro mais do que naquelas dependentes da luz.

EMERSON (1916) encontrou que $\circ$ número de internódios e o comprimento das plantas de feijão eram herdados quantitativamente, com o último apresentando grande sensibilidade às condições ambientais.

COYNE (1969) relatou que a produtividade de um campo de feijão é um assunto complexo, e è composta por três componentes: número de vagens por planta, peso médio daśs sementes e número de sementes por vagem. Coeficientes de correlação negativos são geralmente determinados entre esses componentes indicando que a seleção para aumento em qualquer um deles não leva à melhoria da produtividade total.

ADAMS (1972) considerou como componentes da produção em feijoeiro, o número de vagens por unidade de área, o número médio de sementes por vagem e o peso médio de sementes, 
sendo geralmente encontrada baixa herdabilidade para os dois primeiros, e de média a alta para o terceiro componente. Comentou que os cultivares de feijoeiro diferem bastante quanto aos componentes individuais, mas não tanto quanto a produtividade propriamente dita. Estes comentários concordam em grande parte com Os de COYNE (1969).

DUARTE e ADAMS (1972), analisando os efeitos do número de folhas por planta e área das folhas, no número de vagens por planta, número de sementes/vagem e peso médio das sementes e dos três últimos fatores na produtividade de famílias $F_{3} e F_{4}$ de feijão, determinaram que estes fatores apresentaram um acentuado efeito na produção de sementes. Encontraram também alta correlação entre número de folhas por planta com o número de vagens e área das folhas com o tamanho das sementes.

\section{LAMBERTH (1950) apontou como fatores importantes} no pegamento das vagens do feijoeiro, altas temperaturas diurnas, baixas temperaturas noturnas, baixa umidade relativa, alta ou baixa umidade do solo, alto ou baixo teor de nitrogênio, baixo teor de fósforo, cálcio ou boro do solo, e concluiu que a disponibilidade de água do solo era o fator ambiente mais importante. Concluiu também que o pegamento das vagens era reduzido substancialmente por excesso de água, aparentemente devido à ruptura dos grãos de pólem antes ou durante sua germinação, ou ao deficit hídrico do solo, perto do ponto de murchamento, aparentemente devido à não germinação dos grãos de pólem no estigma, quando não havia condições favoráveis de umidade relativa. 
BERNARDO e outros (1970) apontaram que as maiores produções de feijão foram observadas nos tratamentos em que era feita irrigação quando a tensão da água no solo chegava a 0,50 e 0,65 atm. Nos tratamentos mais úmidos, as plantas apresentaram maior precocidade, e acima de 0,75 atm. de tensão da água no solo as plantas mostraram sintomas de falta de água.

MCMASTER e outros (1965) observaram que a máxima produção de feijão sómente era obtida quando a irrigação era feita antes que a umidade atingisse $60 \%$ da capacidade de campo. Deficiência de água, do florescimento à colheita, diminuia a produção mais que se ocorresse da emergência ao florescimento. Resultados semelhantes foram apontados por KATTAN e FLEMING (1956), HOWE e RHOADES (1961) e MAURER et al. (1969).

HORNER e MOJTEHEDI (1970) determinaram que irrigação quando $1 / 3,2 / 3$ e aproximadamente toda água disponível na região das raízes do feijoeiro era perdida em diferentes fases do ciclo das plantas, as maiores reduções na produção ocorriam, se o déficit de água era aplicado durante o florescimento e início da frutificação. Os maiores déficits de água causaram perdas de 18 a 26\% abaixo dos valores máximos observados. Quando havia efeito da adubação fosfatada ele era mais acentuado sob alto teor de umidade. Os dados indicaram a importância da adubação com fósforo, se necessária, para aumentar a eficiência no aproveitamento da água.

MILIAR e GARDNER (1972) determinaram decréscimos curvelineares na transpiração e na taxa de produção de matéria seca com o potencial de água do solo. Quando este decrescia de -0,28 a 
- 0,40 bares, havia uma redução de 47\% na taxa de produção de matéria seca. Determinaram também que o fechamento dos estômatos devido ao déficit de água resultou numa maior redução na taxa de crescimento do que na transpiração.

DAVIS (1945) indicou que a área foliar não é um parâmetro adequado para a predição de rendimento na cultura do feijoeiro, uma vez que durante o período de florescimento a temperatura máxima e a umidade relativa mínima são dois fatores de grande influência no pegamento das vagens. Temperaturas acima de $23,9^{\circ} \mathrm{C}$ por dois dias sucessivos causaram uma redução de aproximadamente $2 \%$ no pegamento das vagens a cada grau de temperatura acima de $23,9^{\circ} \mathrm{C}$ até $31,1^{\circ} \mathrm{C}$. No entanto, sugeriu que outros fatores tais como temperatura do solo, umidade relativa e intensidade de luz podem diminuir a exatidão da predição de um fator simples.

JONES (1971) apontou que rápidas variações na área foliar específica invalida o método de duas amostragens (colheitas) sucessivas para estimar a taxa de crescimento relativo, e torna difícil a comparação entre variedades quando índices fisiológicos envolvem a área foliar. As variações na área foliar específica parecem ser devidas ao efeito independente da temperatura na taxa de crescimento relativo das folhas e na taxa assimilatória líquida. DALE (1965) encontrou diferenças consideráveis na área total das folhas e de folhas individuais, quando plantas de feijão eram submetidas a períodos de iluminação de uma hora por dia até iluminação contínua em temperaturas de 15 a $25^{\circ} \mathrm{C}$. Sob elevados 
níveis de radiação foi notado um decréscimo na área foliar total sendo este parâmetro uma função quadrática em relação ao total de radiação diária recebida. Aparentemente, o efeito da temperatura na expansão das folhas se deu pelo controle da distribuição da matéria seca entre elas e as demais partes da planta.

COYNE (1968) relatou, que queda de botões florais e falhas no pegamento das vagens são muitas vezes observadas na cultura do feijoeiro, durante períodos de ocorrência de elevadas temperaturas. As mesmas citações são devidas a ADAMS (1972) que observou que grande número de cultivares são muitos sensịveis a temperaturas de 30 a $35^{\circ} \mathrm{C}$ no período do florescimento, alguns cultivares entretanto, florescem e frutificam abundantemente nestas temperaturas.

SONDAHL et al. (1971) estudando as reações fisiológicas de dois cultivares de feijão, sob os termo-períodos $35-25^{\circ} \mathrm{C}\left(35^{\circ} \mathrm{C}\right.$ de temperatura diurna e $25^{\circ} \mathrm{C}$ noturna $), 30--20^{\circ} \mathrm{C}, 25-15^{\circ} \mathrm{C}$ e $20-10^{\circ} \mathrm{C}$, apontaram que há prejuízo no pegamento das flores nas temperaturas mais elevadas e que os cultivares reagem de modo diverso aos diferentes termo-períodos, demonstrando possuírem capacidade de adaptação aos mais diversos regimes climáticos. Indicaram ainda que a matéria seca total apresentou tendência de acréscimo com a diminuição da temperatura.

MACK E SINGH (1969) apontaram que a percentagem de pegamento, número de massa de vagens de feijão foram reduzidos quando as plantas eram submetidas a altas temperaturas durante 0 florescimento, sendo observados reduções na produtividade de até 
55\%. Temperaturas de 28,3 a $38,3^{\circ} \mathrm{C}$ causaram diminuição no teor de carbohidratos nas folhas, sendo o amido mais influenciado que os açúcares.

BIENKLEY (1932) encontrou que a formação dos botões florais e a queda das vagens estavam associadas com elevadas temperaturas máximas, variando este último fator de 44 a $76 \%$ para 6 cultivares de feijão. SMITH e PRYOR (1962) apontaram reduções consistentes no pegamento das vagens em 3 cultivares e também no número de sementes por vagem, no entanto houve diferenças entre cultivares, sendo uns mais sensíveis que outros. Indicaram ainda que as primeiras flores emitidas são mais importantes que as últimas na formação da produção, pois estas apresentam mortalidade muito alta.

STOBBE et al. (1966) obtiveram baixa percentagem de pegamento das vagens no cultivar "Stringless green pod" em câmara de crescimento a temperaturas diurnas e noturnas de $35-26,7^{\circ} \mathrm{C}$ quando comparadas com $29,4-21,1^{\circ} \mathrm{C}$ e $23,9-15,6^{\circ} \mathrm{C}$. As vagens desenvolvidas a $35-26,7^{\circ} \mathrm{C}$ não continham óvulos completamente desenvolvidos, mal formados e pequenos, com subseqüente queda de muitas vagens.

RAPPAPORT e CAROLUS (1956) encontram diferenças na sensibilidade a temperaturas noturnas entre cultivares de feijoeiro que se traduziu principalmente no pegamento das vagens. Temperaturas noturnas baixas que aumentaram a massa de sementes em um cultivar (Henderson), apresentaram efeito contrário em outro (Ford-hook). 
VIGLIERQUIO e WENT (1957) apontaram que as hastes apresentam maior crescimento a temperaturas variando de 20 a $26^{\circ} \mathrm{C}$, sendo que nas fases iniciais do desenvolvimento a taxa de alongação das mesmas é função da temperatura noturna, crescendo com ela. Plantas desenvolvidas sob dias longos (14 horas de luz), cresceram mais depressa que sob dias curtos ( 8 horas de luz), sugerindo que a produção de fotossintetizados pode ser fator limitante em regime de dias curtos. É interessante notar, que dias longos reduziu a magnitude dos efeitos da temperatura noturna. Observaram que o número de folhas cresceu com o aumento da temperatura noturna de 14 a $20^{\circ} \mathrm{C}$ e com a idade das plantas, no entanto foi observado apenas pequeno aumento na área foliar devido a idade das plantas uma vez que muitas folhas novas substituiam a perda de área causada pela queda das folhas velhas.

IZHAR e WALLACE (1967a) determinaram que a absorção de $\mathrm{CO}_{2}$ por plantas com duas semanas de idade era reduzida por baixa temperatura noturna. As plantas desenvolvidas sob temperatura noturna de $10^{\circ} \mathrm{C}$ exibiam pequena taxa de absorção de $\mathrm{CO}_{2}$ por várias horas, com um retorno lento a taxas normais. Apontaram que tal redução na fotossíntese por baixa temperatura noturna pode ser o fator principal na classificação de Phaseolus vulgaris L. e outras espécies como cultura de verão. 


\subsection{Absorção de Nutrientes}

GALLO e MIYASAKA (1961) determinaram as concentrações de macronutrientes nas diversas partes da plantas em várias fases do ciclo da cultura e apontaram que as percentagens dos elementos nas raízes, hastes, folhas e frutos, com exceção do cálcio, decresceram no período do florescimento no início da formação dos frutos e cresceram nos estádios finais do ciclo. Os frutos apresentaram maior teor de nitrogênio e fósforo e teores mais baixos de cálcio, magnésio e enxofre que as demais partes da planta. Potássio, cálcio e magnésio figuram em concentrações mais elevadas nas folhas e o enxofre nas raízes. O acúmulo de nutrientes foi mais intenso no período do florescimento e início da formação das vagens, isto é, do $33^{\circ}$ ao $44^{\circ} \mathrm{dia}$; em $\mathrm{kg} / \mathrm{ha} / \mathrm{dia}$ da ordem de 2,46 kg para nitrogênio, 2,17 kg para potássio, 1,27 kg para cálcio, 0,53 kg para magnésio, 0,27 para fósforo e 0,26 kg para enxofre, nas plantas adubadas. Apresentaram ainda a percentagem de nutrientes exportada pela cultura em relação à quantidade absorvida: nitrogênio $66 \%$; fósforo $67 \%$; enxofre $44 \%$; potássio $33 \%$; magnésio $27 \%$ e cálcio $11 \%$.

COBRA NETTO (1967) apontou serem o nitrogênio e - potássio os elementos absorvidos em maiores quantidades, seguindo-se-lhes o cálcio, enxofre, magnésio e o fósforo. As folhas apresentaram teores mais elevados de nitrogênio, fósforo, cálcio e magnésio. Até $\circ 46^{\circ}$ dia o teor de enxofre nos caules foi mais elevado, a partir desta data as maiores concentrações foram 
observadas nas raízes. Com o desenvolver das plantas, os teores de nitrogênio, fósforo e potássio tenderam a decrescer nos órgãos vegetativos, e o teor de cálcio nas folhas tendeu a aumentar nas últimas fases do ciclo. Nas vagens, os teores de potássio, cálcio e magnésio decresceram com a maturação das plantas, fato inverso ocorrendo com o enxofre. O nitrogênio e o fósforo apresentaram teores mais elevados quando os frutos eram novos, uma diminuição posterior, e nas últimas fases os teores desses dois elementos cresceram. Com referência aos órgãos vegetativos foi apresentada uma tendência no aumento das quantidades absorvidas até $056^{\circ}$ dia de nitrogênio, potássio, cálcio, enxofre e magnésio. Nas vagens, houve um crescimento constante da quantidade de macronutrientes. Considerando boa estimativa de produção, são apontadas as seguintes quantidades de nutrientes absorvidos em kg/ha: nitrogênio 101,6; potássio 92,6; cálcio 54,1; enxofre 25,4; magnésio 17,7 e fósforo 9,1, sendo exportados na mesma unidade $37,2 \mathrm{~kg}$ de nitrogênio, 22,0 kg de potássio, 9,5 kg de enxofre, 4,4 kg de cálcio, 4,4 kg de magnésio e 3,6 kg de fósforo.

HAAG et al. (1967) determinaram no feijoeiro, 'Chumbinho Opaco', uma absorção de 201,2 kg/ha de nitrogênio, 17,5 kg/ha de fósforo, $200,7 \mathrm{~kg} / \mathrm{ha}$ de potássio, $116 \mathrm{~kg} / \mathrm{ha}$ de cálcio, 36 $\mathrm{kg} / \mathrm{ha}$ de magnésio e $36 \mathrm{~kg} / \mathrm{ha}$ de enxofre. Nessas condições, uma produção de $500 \mathrm{~kg} / \mathrm{ha}$ de grãos exportaria 14,3 kg de nitrogênio, 1,1 kg de fósforo, 10,2 kg de potássio, $18 \mathrm{~kg}$ de cálcio, 1,0 kg de magnésio e $2,2 \mathrm{~kg}$ de enxofre. Observaram ainda que o máximo de crescimento foi atingido quando as plantas completaram 50 dias de 
idade e que o nitrogênio, potássio e cálcio necessários, foram absorvidos até este período. O enxofre foi absorvido até o $60^{\circ}$ dia e o magnésio até $\circ 70^{\circ}$, sendo o fósforo absorvido até o final do ciclo. Determinaram que as concentrações de nitrogênio, fósforo e potássio são mais elevadas por ocasião do florescimento e decrescem com o desenvolvimento da planta, sugerindo translocação deste elemento às vagens e sementes, sendo que fato diverso ocorre com o cálcio, cuja concentração aumenta nas folhas. Os teores de enxofre e magnésio determinados, apresentaram pequena variação no decorrer do ciclo do feijoeiro.

BRUNS, citado por COBRA NETTO (1967) constatou em condições de campo que grandes quantidades de nitrogênio eram necessárias desde o início do desenvolvimento até a maturação das plantas, o fósforo foi absorvido durante todo o ciclo, não apresentando épocas preferenciais. O cálcio foi absorvido em maior quantidade no início do ciclo. das plantas, o magnésio apresentou absorção preferencial durante o florescimento, e o potássio apresentou a tendência semelhante, porém em quantidades mais elevadas.

CABALLERO et al. (1985) mostraram que a absorção de nitrogênio foi até ao redor do $80^{\circ}$ dia após a germinação, embora tenham discutido que diferenças possam ser devidas ao ciclo do cultivar utilizado. MORAIS (1988) apontou que a pronta disponibilidade de nutrientes logo após a germinação é essencial para o estabelecimento adequado da cultura, e considerou que nos primeiros 35-40 dias 75 a $85 \%$ da matéria seca das raízes é 
produzida. Segundo COBRA NETO (1967), qualquer limitação ao crescimento das plantas logo após a germinação, compromete o seu desempenho.

MALAVOLTA (1969) destacou como adequados os seguintes teores nas folhas de feijoeiro: nitrogênio 2,61\%; fósforo $0,36 \%$; potássio 4,45\%; cálcio 4,01\%; magnésio $0,86 \%$ e enxofre $0,81 \%$. Estes valores, exceto para o nitrogênio, estão bem acima dos determinados por GALLO e MIYASAKA (1961) e exceto para potássio, cálcio e nitrogênio, estão acima dos determinados por HAAG et al. (1967).

COBRA NETTO et al. (1971) apontaram os seguintes teores nas folhas do feijoeiro como caracterizando deficiência de nutrientes: nitrogênio 1,54\%, fósforo 0,13\%, potássio 0,93\%, cálcio $0,42 \%$, magnésio $0,48 \%$ e enxofre $0,70 \%$.

MAFRA (1972) determinou que a época de plantio influenciou a concentração dos nutrientes nas diferentes partes da plantas. De maneira geral na época "da seca" foram encontradas menores teores de fósforo e potássio e maiores de nitrogênio, cálcio e magnésio em relação à época "das águas". Nas duas épocas, - aumento da densidade de plantio causou acréscimo no teor de cálcio nas raízes e decréscimos no das folhas. A extração em kg/ha de nutrientes pelas sementes foi, no período "das águas", de nitrogênio 36, fósforo 4, potássio 26, cálcio 16 e magnésio 9, e no período "da seca" foi de nitrogênio 24, fósforo 2, potássio 14, cálcio 12 e magnésio 6. As quantidades de nutrientes nas sementes 
variaram não somente com a densidade e época de semeadura mas também com o tipo de nutriente.

HESTER et al. (1951) determinaram a curva de absorção de vários nutrientes em média de 3 anos de observações. Para uma produção aproximada de $1.700 \mathrm{~kg} / \mathrm{ha}$ de matéria seca (vagens + sementes), ao fim de 10 semanas após a emergência, a extração foi da ordem de $134,4 \mathrm{~kg}$ de $\mathrm{K}_{2} \mathrm{O}, 92,6 \mathrm{~kg}$ de nitrogênio, 66,8 kg de cálcio, $40,9 \mathrm{~kg}$ de $\mathrm{P}_{2} \mathrm{O}_{5}$ e $9,7 \mathrm{~kg}$ de magnésio. Exceto para magnésio e fósforo, a taxa de absorção de potássio, nitrogênio e cálcio apresentou grande intensidade a partir da segunda semana após a emergência.

HAAG et al. (1971) comentaram que cultivares de feijoeiro diferiram no acúmulo de fósforo, potássio, cálcio e magnésio e as partes das plantas (raízes, hastes e folhas) responderam diversamente quanto ao acúmulo desses nutrientes em vários níveis de fósforo aplicado. Sugerem que cultivares de feijão possuem propriedades genéticas que regulam o modelo de respostas aos nutrientes minerais.

AMARAL et al. (1980) apontam, com relação ao comportamento diferencial entre cultivares, que embora um grupo de cultivares tenha produzido 3.7 vezes mais que outro, as extrações médias de nitrogênio, fósforo e potássio foram apenas 1.5, 1.4 e I. 5 vezes maiores respectivamente, demonstrando grande diferença na eficiência de conversão entre nutriente extraído e grão produzido. Isto se traduz em que, no primeiro grupo para cada unidade de feijão produzida foram utilizados em média $61 \mathrm{~g}$ de $\mathrm{N}, 8,5 \mathrm{~g}$ de $\mathrm{P}$ e 
$50,6 \mathrm{~g}$ de $\mathrm{K}$, já no segundo esta relação foi de $153 \mathrm{~g}$ de $\mathrm{N}, 22,9$ de $\mathrm{P}$ e $127 \mathrm{~g}$ de $\mathrm{K}$ por quilograma de feijão produzido.

GREENE e BUKOVAK (1968) determinaram em feijoeiros desenvolvidos em solução nutritiva, contendo ou não cálcio, que o mesmo era transportado das raízes e partes inferiores das hastes para as partes superiores das plantas, sendo seu movimento aumentado quando as plantas eram submetidas à déficit de cálcio. Este elemento, depositado nas folhas inferiores, após absorção pelas raízes era redistribuído para os tecidos novos, sendo esta redistribuição independente do "status" do cálcio na planta. Concluíram finalmente que o movimento do cálcio na planta envolvia contínua distribuição e redistribuição.

VIETS et al. (1954) determinaram que os teores de cálcio e magnésio eram mais elevados nas folhas maduras e em início de senescência e menores nas partes em desenvolvimento. A distribuição destes dois nutrientes nas partes das plantas é aproximadamente inversa daquela do nitrogênio, zinco e fósforo.

BIDDULPH et al. (1959) apontaram que o cálcio não é sujeito a uma redistribuição significativa a partir das folhas e pode ser esperado que a quantidade nelas depositadas dali não seja removida.

BIDDULPH et al. (1961) indicaram que o volume do fluxo respiratório é fator importante no acúmulo de cálcio. Também notável foi a pequena perda após deposição inicial, dificultando sua reutilização no crescimento e metabolismo de outras partes da planta. Determinaram que a quantidade de cálcio exportada pelas 
folhas, quando aplicado via foliar é aproximadamente 1/100 daquela do fósforo sob condições de máxima percentagem de exportação, sendo a quantidade exportada por uma folha relacionada à quantidade aplicada e não à condição de nutrição imposta à planta. O cálcio, uma a vez depositado nas folhas, não é deslocado em quantidade significativa para suprir outras folhas no período subseqüente, indicando que o crescimento da planta é dependente do cálcio absorvido do meio, sendo pouco mobilizado de deposições anteriores. CAROLUS (1938) apontou que a adição de cálcio ao solo não somente acentuou sua absorção, mas implicou em maior absorção de magnésio e em alguns casos foi levemente benéfica à absorção de potássio.

FOY et al. (1967) apontaram que cultivares de feijão diferem muito em crescimento da parte aérea e raízes em solos ácidos $(\mathrm{pH} 4,4)$ e em sua resposta à calagem, salientando que provavelmente, a toxidez de alumínio é o principal fator na limitação do crescimento, e que certos cultivares diferem em sua tolerância ao alumínio. Com poucas exceções, os cultivares do Sul e Leste dos E.U.A. mostram maiór tolerância a este elemento. Tais cultivares apresentaram raízes mais profundas em subsolos ácidos com níveis elevados de alumínio e fariam melhor uso da água e nutrientes das camadas mais profundas do solo.

BERNSTEIN e AYRES (1951) encontraram diferenças entre cultivares de feijoeiro sob gradiente salinidade. Para todos os cultivares houve detrimento na produção com aumento da salinidade, apesar de alguns cultivares serem mais tolerantes. 
Comentaram, entretanto, que o feijoeiro é mais sensível à salinidade que outras culturas. Com o aumento da mesma no substrato, o acúmulo de magnésio e de potássio apresentou tendência de diminuição. Em presença do substrato rico em cálcio, há acréscimo no acúmulo deste cation bem como aumento na razão cálcio/outros cations. Apontaram que esta relação provavelmente deve ser importante na determinação da resposta do feijoeiro à salinidade, no entanto sua composição química' não permite explicação para diferença na tolerância à salinidade entre cultivares.

GAUCH e WADLEIGH (1945) indicaram que adição de doses crescentes de cloreto de cálcio na solução nutritiva resultou no aumento da concentração de cálcio nas folhas, hastes e raízes do feijoeiro, mas este aumento não foi proporcional à quantidade aplicada. A adição à solução nutritiva de sais contendo sódio causava moderado aumento de cations nas hastes e acentuada nas raízes, sendo a concentração das folhas pouco afetada. Em presença de cloreto de cálcio na solução, a concentração de potássio nas folhas era inversamente relacionada à do cálcio. Quando adicionaram à solução nutritiva sulfato de sódio, havia um decréscimo no teor de cálcio e aumento no de potássio das folhas. Apontam ainda que a adição de sais, em doses crescentes, à solução nutritiva, quase não afetava o teor de fósforo nas diversas partes da planta e que a absorção de sais pelas plantas de feijão envolve uma complexa série de processos interrelacionados. 
LUNIN et al. (1964a,b) apontaram que a quantidade de cálcio e de magnésio na parte aérea das plantas foi intimamente relacionada com seus teores no substrato, ocorrendo decréscimo na produção de matéria seca com aumento da disponibilidade de sódio, principalmente se era mantida a mesma concentração de cálcio e magnésio no substrato. Aumento no teor de sódio do substrato causava aumento na quantidade de potássio na parte aérea sem entretanto modificar o acúmulo de sódio na parte aérea, exceto se sua concentração fosse muito elevada no substrato.

HENDRIX (1967) apontou que a absorção de fósforo a pH acima de 6,0 segue aproximadamente a concentração de $\mathrm{H}_{2} \mathrm{PO}_{4}$ na solução. A pH 4,0 na solução nutritiva a absorção de fósforo foi linearmente proporcional à transpiração e a pH 8,7 sua absorção ocorreu somente no início do experimento e que nestas condições o fósforo foi absorvido como resultado de depressão do pH no local da absorção.

MELTON et al.(1970) determinaram crescimento reduzido do feijoeiro tanto pela deficiência de zinco (menos que 20 ppm na parte aérea) quanto pela toxidez (acima de 50 ppm). Em solos com pH 7 ou acima e que continham $\mathrm{CaCO}_{3}$ livre, aplicações de elevadas quantidades de fósforo induziram deficiência de zinco em feijoeiro. Em solos ácidos a aplicação de zinco geralmente diminuia a produtividade, entretanto, nestes mesmos tipos de solos, a calagem podia induzir a deficiência de zinco.

AMBLER e BROWN (1969) demonstraram em dois cultivares com diferença na susceptibilidade à deficiência de zinco 
que a absorção de ferro e fósforo era muito maior nas plantas que mostravam sintomas de deficiência de zinco, quando no substrato a concentração deste era baixa e as de ferro e fósforo relativamente alta. Esta maior absorção acentuava os sintomas de deficiência em uma das variedades.

POLSON \& ADAMS (1970) cultivaram feijoeiros 'Saginaw' e 'Sanilac' em substrato de areia, com diferentes níveis de zinco, cobre, ferro e magnésio. Enquanto o cultivar saginaw desenvolveu-se normálmente ao nível de 5 ppm de zinco no substrato o outro foi extremamente prejudicado. As diferenças relatadas não foram relacionadas com os teores absorvidos ou redistribuídos pois a diferença na composição elementar dos dois cultivares não foi de tal magnitude para serem biologicamente significantes.

SCHELLENBERGER e ADAMS (1971) estudando o comportamento das variedades Sanilac e Saginaw quanto à sua resposta a teores de zinco no substrato encontraram que a primeira acumula elevadas quantidades deste elemento nas hastes e pecíolos, e este acúmulo era associado a baixos teores de fósforo nas folhas. Essés autores apontaram como explicação provável que a passagem do zinco através de tecidos ricos em fósforo, como as raízes, hastes e pecíolos, na variedade Sanilac, resultou em fixação do zinco numa forma molecular com o fósforo, conseqüentemente, nesta variedade sob baixo "status" nutricional de zinco, uma quantidade insuficiente do mesmo chega às folhas para manter os processos metabólicos dele dependentes. 
BOAWN et al. (1969) determinaram que o número de dias do plantio à colheita é relacionado ao teor de zinco tanto nas folhas, como na parte aérea no período de pré-florescimento. Apontaram que o período ótimo de maturação é associado à 20 ppm ou mais de zinco nesses tecidos. Abaixo deste valor, o número de dias para atingir a maturidade cresce rapidamente sendo observado que com teor menor que $15 \mathrm{ppm}$ de zinco ocorreu um aumento superior a 30 dias para as plantas atingirem a maturidade.

EHRLER et al. (1958) determinaram que a quantidade de cálcio e fósforo na parte aérea das plantas dependia do teor desses elementos no substrato. A absorção de cálcio estaria relacionada com a quantidade de fósforo na solução, mas a absorção de fósforo não dependia do suprimento de cálcio. A quantidade de fósforo na parte aérea dependeu da quantidade de magnésio na solução, mas não estava relacionada com as quantidades de potássio, sulfato ou nitrato.

SHEA et al. (1967) apontaram que a habilidade do feijoeiro em produzir crescimento normal sob níveis baixos de potássio disponível parece estar associada com a eficiência no uso do potássio no interior das plantas mais do que uma assimilação mais intensa, uma vez que seu conteúdo nas partes aéreas das plantas era semelhante.

HIROCE et al. (1969) apontaram que a adubação mineral nitrogenada aumentou significativamente os teores de nitrogênio total das folhas de feijoeiro, amostrados no período do florescimento e que houve correlação da produção de sementes com o 
teor de nitrogênio dos pecíolos e com o teor de potássio dos folíolos.

HIROCE et al. (1970) apontaram que o teor de fósforo total dos folíolos das plantas de feijoeiro pode ser usado como índice para diagnose na nutrição fosfatada, sendo o teor adequado de $0,33 \%$ de fósforo para uma produção correspondente a $80 \%$ da máxima. Concluíram ainda que a fertilização fosfatada aumentou os teores de fósforo nos folíolos e que a calagem aumentou os teores de cálcio e magnésio. Ambos os fatores aumentaram a produção final de grãos.

LUNIN et al. (1964b) relatam que o conteúdo de cations nas folhas e caules é mais relacionado com o extrato saturado da solução do solo do que com os teores trocáveis,. sendo que o teor de nitrogênio decresce com o aumento do peso total da planta sendo geralmente encontrados teores maiores de nitrogênio em condições de baixa fertilidade do solo. Determinaram que a adubação com NPK não afetava apreciavelmente o acúmulo de cations, exceto para o potássio que aumentava o teor de cálcio nas folhas mas não afetava os demais cations. A adição de N, P e K associados à calagem não alterou substancialmente o teor desses elementos nas plantas.

MIYASAKA et àl. (1966) estudando métodos de manejo do solo para o feijoeiro encontraram efeitos sensíveis da incorporação de matéria orgânica imediatamente antes do plantio do feijoeiro na diminuição das variações térmicas da superfície do solo, na maior disponibilidade de água às plantas e determinaram 
também teores significativamente superiores de potássio nas folhas de feijão. Atribuíram melhor produtividade final de grãos aos fatores acima citados.

LANGE et al. (1959) determinaram em solução nutritịva, que a absorção de cálcio pela parte aérea foi maior a $\mathrm{pH}$ 5,5 enquanto que a de fósforo $\circ$ foi a $\mathrm{pH} 7,0$. Baixando-se a temperatura das raízes de $27^{\circ} \mathrm{C}$ a $17^{\circ} \mathrm{C}$ houve tendência de aumento do teor de cálcio na parte aérea, o mesmo não foi observado para o fósforo. A diminuição da intensidade luminosa de 1.100 "footcandles" para 450 "foot-candles" causou um acúmulo maior, na parte aérea de 30\% para cálcio e 50\% para fósforo. Uma aparente interação entre temperatura das raízes e intensidade luminosa parece afetar a absorção de cálcio mas não a do fósforo.

APPLE e BUTTS (1953) determinaram que o crescimento das plantas e a absorção do fósforo aumentaram com o aumento da temperatura do solo no intervalo entre 12,2 e $27,8^{\circ} \mathrm{C}$.

SINGH e MACK (1963) determinaram melhores crescimento, florescimento e frutificação à temperaturas do solo variando entre 24 e $29,4^{\circ} \mathrm{C}$. Variações diárias entre 15,5 a $21,1^{\circ} \mathrm{C}$ e 21,1 a $26,6^{\circ} \mathrm{C}$ apresentaram produções semelhantes que à temperatura constante. Não foram encontrados efeitos consistentes da temperatura do solo nos teores de nitrogênio, cálcio e magnésio das plantas. Nas temperaturas mais elevadas foram observadas maiores massas secas de hastes e raízes e maiores teores de fósforo e potássio nas hastes. As condições onde as plantas se desenvolvem e seu estádio de crescimento afetaram a absorção e a distribuição de 
nutrientes no feijoeiro. MAFRA et al. (1974) determinaram que em épocas mais chuvosas era maior a quantidade de nutrientes encontrados nas plantas. OLIVEIRA e THUNG (1988) apontaram que as análises realizadas em tecidos de plantas desenvolvidas em casa de vegetação apresentam maiores quantidades absorvidas que os tecidos de plantas desenvolvidas em campo, comparando os dados de COBRA NETO (1967) e HAAG et al. (1967) consideram que esta situação é reflexo do maior contato entre as raízes das plantas e os ions presentes nos vasos. Esses autores ainda consideraram que variações observadas na absorção de nutrientes por diversos autores são decorrência das diversas condições em que se desenvolveram as plantas além dos diferentes cultivares envolvidos.

MACKAY e LEEFE (1962) determinaram em dois anos sucessivos, que os níveis ótimos de nitrogênio, fósforo e potássio nas folhas do feijoeiro diferiram em 12, 29 e 11\% respectivamente. Déficit de água era geralmente associado a teores mais baixos que o ótimo para os três nutrientes, mas, elevada umidade apresentou pequeno efeito. Os níveis calculados, para ampla variação na disponibilidade de umidade, foram para folhas maduras, colhidas no início do florescimento de $5,1 \% ; 0,40 \%$ e 2,0\% para nitrogênio, fósforo e potássio respectivamente.

THOMAS et al. (1942) indicaram que os teores de nitrogênio, cálcio e magnésio eram menores em plantas submetidas à irrigação enquanto que os teores de fósforo e potássio eram maiores. 
JANES (1948) encontrou no feijoeiro e em parcelas irrigadas teores menores de nitrogênio e fósforo e maiores de potássio. Já os teores de cálcio e magnésio não eram afetados pela maior disponibilidade de água.

KATTAN e FLEMING (1956) determinaram que os teores de nitrogênio, potássio e fósforo das folhas diminuiam com a idade das plantas, sendo esta diminuição mais acentuada com o nitrogênio e mais intensa quando as plantas se desenvolviam em boas condições de umidade, sendo posteriormente submetidas à falta de água. Nessas condições o efeito da umidade do solo era mais intenso sobre o fósforo e o potássio. O teor nas folhas de fósforo e potássio era sempre mais alto com irrigação no início do florescimento e formação das vagens. Concluíram então que para se atingir a máxima produção, a manutenção da umidade do solo é éssencial do florescimento ao período de formação das vagens. 


\section{MATERIAL E MÉTODOS}

o experimento, objeto deste trabalho, foi conduzido em casa de vegetação (Blue Ribbon, 20 Century Glasshouse) provida de ventilação forçada, no período de junho a setembro. Foram utilizados para semeadura, vasos de polietileno branco contendo cada um $12 \mathrm{~kg}$ de terra (latossolo roxo epieutrófico textura argilosa), proveniente do Centro Experimental de Campinas, e cuja análise química apresentou os seguintes resultados: pH $\left(\mathrm{CaCl}_{2}\right)-5,6 ; \mathrm{M} . \mathrm{O} .-2,0 \% ; \mathrm{P}-15 \mathrm{ppm}$ e em e.mg/100mg $\mathrm{K}-0,12, \mathrm{Ca}$ $-2,2, M g-0,6$ e $H+A l-1,5$, determinadas segundo metodologia preconizada por RAIJ e QUAGGIO (1983).

Cada vaso recebeu antes da semeadura $1,5 \mathrm{~g}$ de sulfato de amônio, $4 \mathrm{~g}$ de superfosfato simples e 0,5 g de cloreto de potássio, correspondente a uma fertilização de $30 \mathrm{~kg} / \mathrm{ha}$ de nitrogênio, $80 \mathrm{~kg} / \mathrm{ha}$ de $\mathrm{P}_{2} \mathrm{O}_{5}$ e $30 \mathrm{~kg} / \mathrm{ha}$ de $\mathrm{K}_{2} \mathrm{O}$, baseada numa população ideal de 200.000 plantas/ha num espaçamento de 0,5 m entre linhas com 10 plantas por metro linear, ou 5 covas com 2 plantas a cada $0,2 \mathrm{~m}$. Além desta adubação, cada vaso recebeu $0,5 \mathrm{~g}$ 
dos sulfatos de cálcio e de magnésio, 0,2 g dos sulfatos de zinco, cobre e manganês, $50 \mathrm{mg}$ de tetraborato de sódio e $10 \mathrm{mg}$ de molibdato de amônio. Todos os fertilizantes foram misturados ao solo seco no terço superior do solo dos vasos.

Foram colocadas 4 sementes por vaso dos cultivares Bico de Ouro, Carioca, Goiano Precoce, Rico 23 e Rosinha G-2, efetuando-se o desbaste logo após a emergência, deixando-se 2 plantas em cada vaso, as mais homogêneas. Os cultivares Bico de Ouro, Carioca e Rosinha G2 são considerados como plantas do tipo III, Rico 23 do tipo II e Goiano precoce do tipo I, segundo proposta de classificação do CIAT (Centro Internacional de Agricultura Tropical, Cali, Colombia). As plantas de tipo I apresentam hábito de crescimento determinado e porte arbustivo, as do tipo II mostram hábito de crescimento indeterminado, e porte arbustivo (eretas) e as do tipo III crescimento indeterminado. (Considerou-se como o dia zero da emergência a data em que as plântulas apresentavam o primeiro par de folhas abertas, com um comprimento aproximado de $7 \mathrm{~cm}$ e uma largura de $6 \mathrm{~cm}$. Dez dias após, e depois sucessivamente de dez ém dez dias foram efetuadas as amostragens. Foram semeados ao todo 400 vasos, 80 para cada cultivar, correspondentes a 8 amostragens.

Cada amostragem ou coleta consistia na colheita de 10 vasos de cada cultivar, cujas plantas eram cortadas ao nível do solo, lavadas, separadas em órgãos e colocadas em secador com circulação forçada de ar a uma temperatura de $65^{\circ} \mathrm{C}$ para secagem até massa constante. Procedeu-se à separação das raízes, emborcando-se 
os vasos sobre uma peneira para a eliminação da terra. As raízes foram então lavadas e postas a secar juntamente com os demais órgãos das plantas.

Antes de se proceder à secagem, as hastes foram medidas para determinação da altura das plantas, e desenhado o contorno das folhas em papel manilha. Posteriormente foi efetuada a contagem do número de folhas, recortou-se o papel e através de pesagem foi determinada a área foliar, pela relação da massa específica do papel com a massa determinada.

O preparo das amostras e as determinações dos teores totais de nitrogênio, fósforo, potássio, cálcio e magnésio foram feitos segundo metodologia descrita por BATAGLIA et al. (1983) na seção de Fertilidade do solo e Nutrição de Plantas do Instituto Agronômico.

$\mathrm{Na}$ distribuição dos vạsos dentro da casa de vegetação, foi observada a casualização tanto para cultivares quanto para amostragem, além disto periodicamente efetuou-se um rodízio dos mesmos de maneira a se evitar eventual efeito de local no interior da casa de vegetāção (proximidade de paredes, etc.). A análise estatística dos resultados obtidos obedeceu a um delineamento inteiramente casualizado constando de cinco tratamentos e dez repetições.

Para as determinações fenológicas considerou-se como parcela o total obtido em cada vaso, e o material destinado à análise química foi obtido pela moagem e homogeneização de todas as repetições. 
Os valores diários de temperatura e umidade relativa foram registrados através de aparelho termohigrógrafo (The Bendix Corporation) colocado na altura dos vasos, na posição mediana da casa de vegetação sendo transcrita a temperatura e umidade relativa de duas em duas horas, anotados os valores máximos e mínimos, e considerando-se o valor médio diário como a média aritmética de doze observações de 0 a 24 horas.

Todos os vasos foram irrigados diariamente com quantidade de água não determinada, entretanto cuidou-se de evitar tanto o encharcamento da terra e a percolação, quanto a falta de água, mantendo-se o solo sempre perto de sua capacidade de campo. No final do florescimento e início do período de granação, um ataque incipiente de oídio (Erysiphe poligoni DC et Merat) foi eficientemente controlado com uma pulverização com dinitrofenil crotonato a $22,5 \%$ na base de $0,5 \mathrm{~g} / 1$ do produto comercial (Karathane WD), gastando-se 2 litros da solução para tratamento de todas as plantas remanescentes na ocasião. 


\section{RESULTADOS E DISCUSSÃO}

\subsection{Condições Ambientais}

São apresentados na figura 1 as temperaturas máximas, médias e mínimas diárias anotadas no decorrer do ciclo das plantas. Apesar de o experimento ter sido conduzido em casa de vegetação não foi observada ocorrência de temperaturas máximas elevadas principalmente no período do florescimento, que se iniciou ao redor do $35^{\circ}$ dia de idade das plantas e se estendeu até aproximadamente $\circ 54^{\circ} \mathrm{dia}$. Neste período observou-se apenas por 4 vezes em dias não consecutivos, a ocorrência de $31^{\circ} \mathrm{C}$. Apenas uma vez foi observada temperatura mínima de $12^{\circ} \mathrm{C}$ já no final do florescimento, sendo maior a freqüência de valores ao redor de $17^{\circ} \mathrm{C}$. A temperatura média calculada esteve ao redor de $20^{\circ} \mathrm{C}$, sendo que no início do florescimento, ocorreram por 2 dias os menores valores, de aproximadamente $15^{\circ} \mathrm{C}$. Estas temperaturas são consentâneas com o esperado uma vez que o experimento foi conduzido durante o inverno. 
Devido ao desenvolvimento das plantas em vasos e às irrigações diárias, não se observou em nenhuma ocasião qualquer défice hídrico nas plantas e nem água livre sobre as plantas, exceto aquela de condensação causada principalmente pela queda da temperatura nas primeiras horas do dia, coincidindo com os valores mais elevados de umidade relativa, sem entretanto causar lavagem nas partes aéreas. Na figura 2 é apresentada a curva de umidade relativa máxima, média calculada e mínima observada durante o ciclo das plantas. Observa-se uma predominância de umidades relativas mais altas durante o desenvolver do ciclo do feijoeiro. Verificase, também, que de um ponto para outro, a umidade relativa mínima é o dado que apresenta variações mais extensas, apresentando semelhança a este respeito com a curva de temperatura máxima. Tendo-se em vista estes resultados, pode-se considerar que foram ideais as condições de temperatura para desenvolvimento do feijoeiro. Como a água foi provida por irrigação e nas condições de aproximadamente $23^{\circ}$ de latitude sul tanto a radiação solar quanto o fotoperíodo foram condutivos à expressão do potencial produtivo da espécie. Essa assertiva pode ser observada tanto pelo crescimento das plantas quanto pela produtividade de grãos observada. 


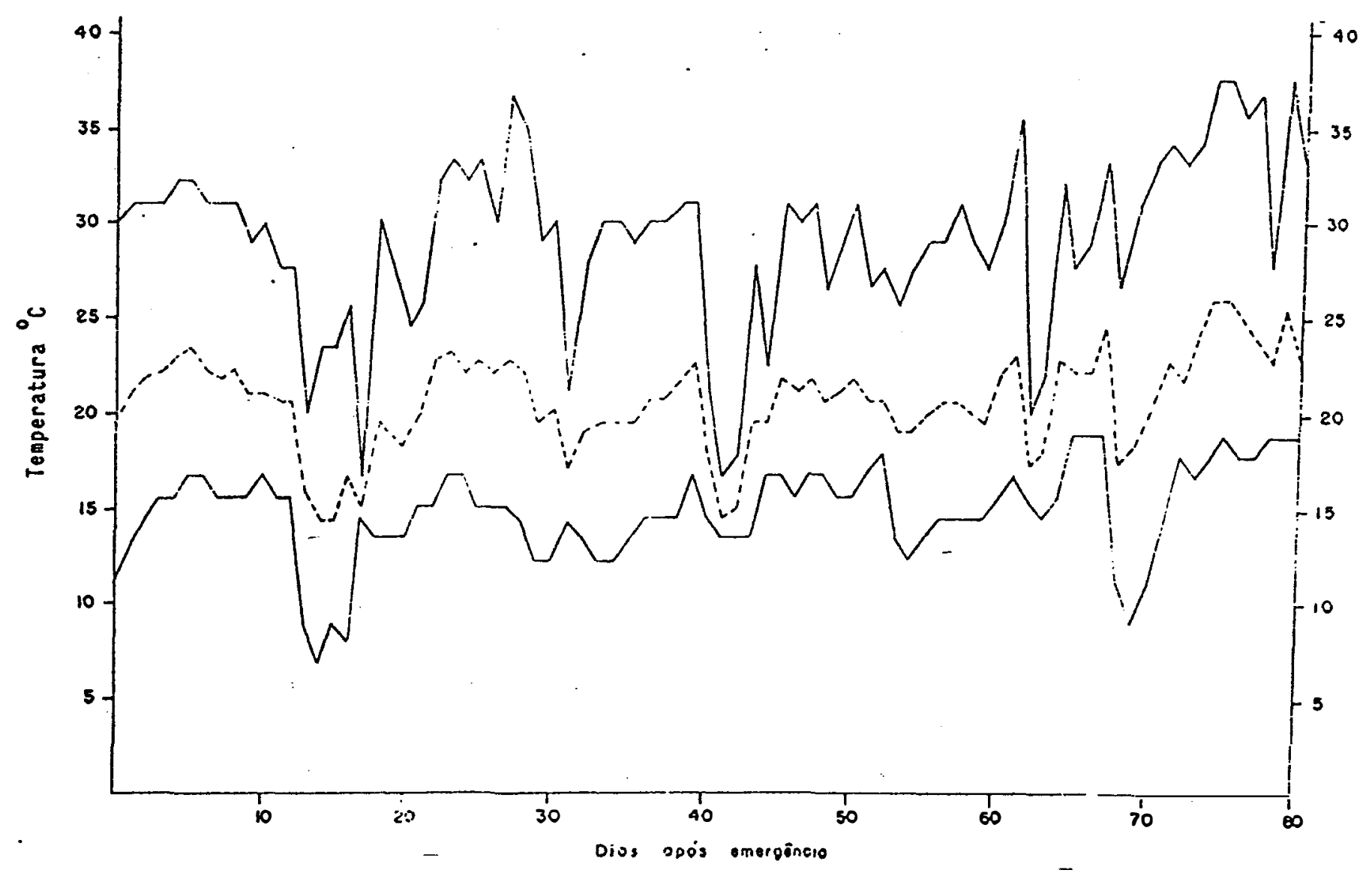

FIGURA 1. Temperatura máxima, média e mínima do ar, durante o ciclo do feijoeiro. 


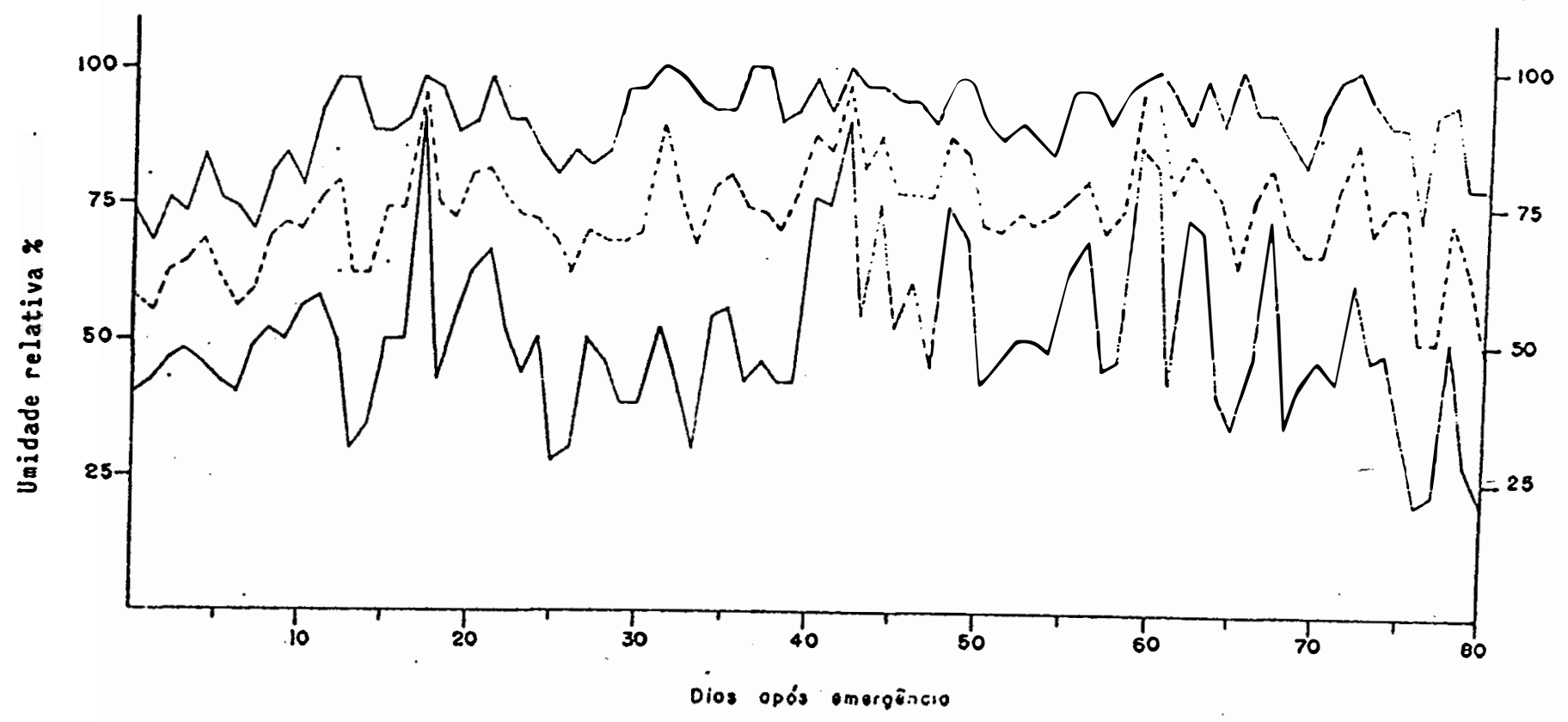

FIGURA 2. Umidade relativa do ar máxima, média e mínima durante o ciclo do feijoeiro. 


\subsection{Crescimento das plantas}

Considerando-se que o ambiente não impediu a plena expressão do potencial de crescimento da planta feijão, são apresentados os valores de produção de matéria seca e outros Índices fisiológicos dos cinco cultivares testados.

No figura 3 verifica-se a evolução de produção de matéria seca das raízes segundo as idades das plantas. As diferenças observadas devem-se mais provavelmente a fluxos de crescimento e estão certamente ligados ao ciclo das plantas, assim é que aś raízes de Bico de Ouro, Goiano Precoce e Rico 23 reduziram seu crescimento aos 40 dias; Rosinha G2 aos 50 e Carioca somente aos 60. Este fato pode estar relacionado a atividade do sistema radicular o que explica em determinadas circunstâncias a maior produtividade deste cultivar em função de sua absorção de água e nutrientes em períodos mais tardios em seu ciclo.

Apesar das diferenças nas curvas que representam - crescimento das raízes de feijoeiro, todas elas apresentam a mesma tendência. Depois de um crescimento lento até o $20^{\circ}$ dia após a emergência, a taxa de acúmulo se acentua até $040^{\circ}$ dia, para então haver uma estabilização e posteriormente um decréscimo, causado pelo fenecimento e decomposição do sistema radicular à semelhança do que já apontado por COBRA NETTO (1967) e HAAG et al. (1967). 


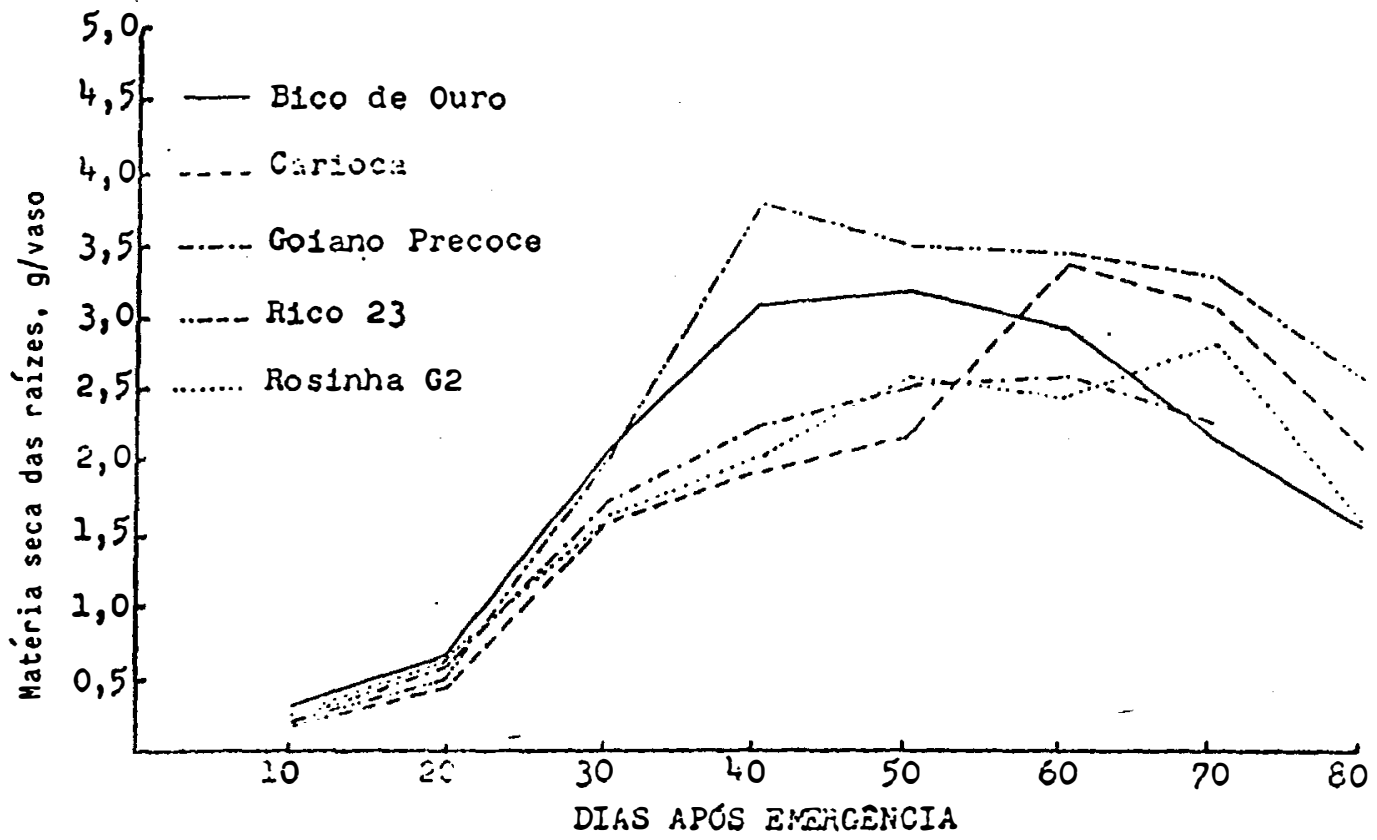

FIGURA 3. Produção de matéria seca das raízes do feijoeiro, em g/vaso, contendo cada um duas plantas (média de 10 vasos). 
Conforme demonstra a figura 4 a curva de crescimento dos caules é algo semelhante à das raízes porém a taxa de acúmulo acentua-se somente a partir do $40^{\circ}$ dia após a emergência, sendo os maiores valores atingidos entre os 50 e 60 dias após a emergência, havendo posteriormente uma redução na matéria seca dos caules, quando a plantas se aproximam do estágio de maturação completa. Verifica-se que Goiano Precoce pela sua menor estatura, planta do tipo I, foi equivalente aos demais cultivares até os 50 dias após a emergência, período após o que ele entrou em maturação e senescência. Pelo desenvolvimento da matéria seca dos caules, Rico 23 diferiu um pouco dos demais, demonstrando ser cultivar mais tardio, pois seu maior valor de produção de matéria seca de caule só foi observado 70 dias após a emẹrgência. A redução final dos valores de matéria seca dos caules também pode ser explicada pela migração dos fotossintetizados desta parte da planta para'as partes reprodutivas, BRANDES (1971).

A produção de matéria seca das folhas, segue uma tendência bastante normal e definida pelo seu número e área; BRANDES (1971), WALLACE e MUNGER (1966), LOPES e outros (1983). Na figura 5 estão expressas as curvas de acúmulo de matéria seca. A partir do $20^{\circ}$ dia após a emergência há um crescimento acentuado, que perdura por 30 dias, quando então o acúmulo de matéria se estabiliza. Para o cultivar Goiano Precoce, pelo seu ciclo e 


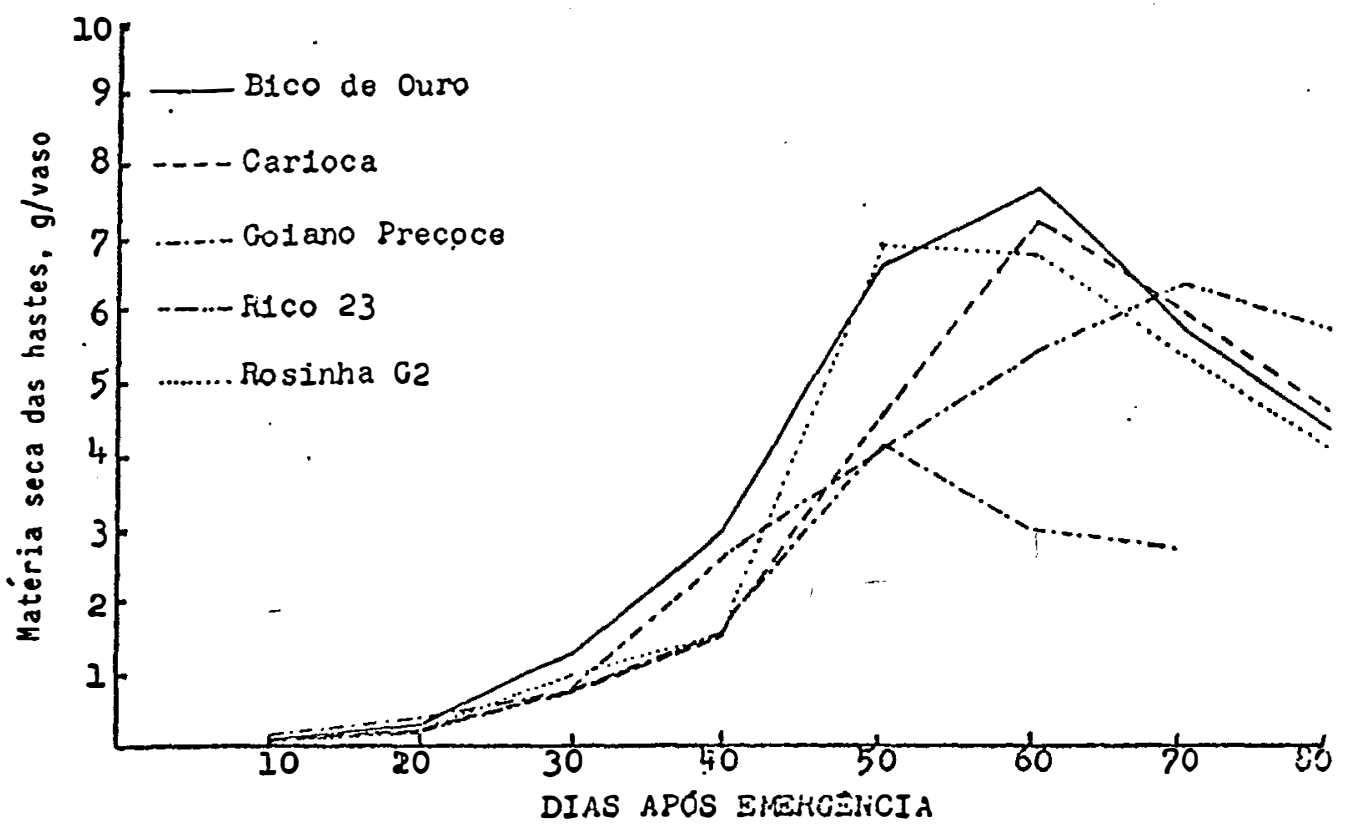

FIGURA 4. Produção de matéria seca das hastes do feijoeiro em g/vaso contendo cada um duas plantas (média de 10 vasos). 


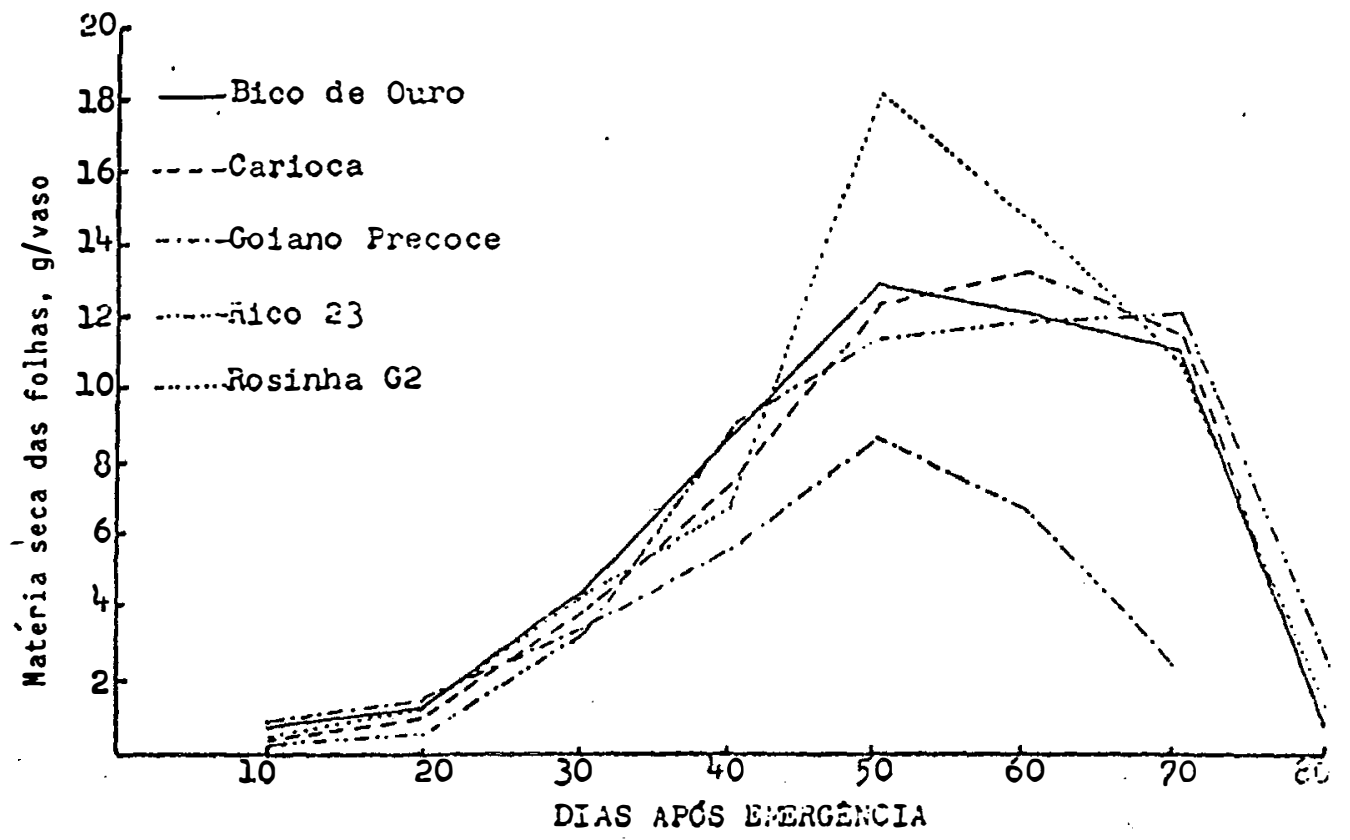

FIGURA 5. Produção de matéria seca das folhas do feijoeiro em g/vaso contendo cada um duas plantas (média de 10 vasos). 
hábito de crescimento, logo após atingido os valores mais elevados inicia-se a redução na massa seca das folhas em função da translocação de fotossintetizados e paralisação na emissão de novas folhas e sua expansão. Nos demais cultivares há estabilização na produção das folhas até os 70 dias, quando então observa-se uma redução abrupta devido à senescência e queda das mesmas (figuras 5 e 9).

A produção de matéria seca das partes reprodutivas iniciou-se aos 40 dias com a contribuição das flores. Estas perduraram por 10 a 20 dias dependendo do ciclo e hábito de crescimento das plantas. Goiano Precoce, de ciclo curto e planta do tipo I apresenta florescimento compacto e de curta duração, já Bico de Ouro, Carioca, Rico 23 e Rosinha G2 mostraram um período de florescimento mais longo, porém com diferenças entre si se observarmos os valores absolutos do quadro 1 . Bico de Ouro apresenta florescimento mais concentrado e mais precoce que os demais cultivares. Carioca, Rico 23 e Rosinha $\mathrm{G} 2$ são mais homogêneos no período de florescimento, mas, este último com uma tendência inversa aos dois primeiros. Já a produção de matéria seca das vagens, dependente de seu desenvolvimento e de seu número deve ser considerado juntamente com os valores do quadro 2, uma vez que esta medida corresponde apenas às vagens imaturas, e quando no final do ciclo das plantas as sementes eram retiradas. Neste contexto fica clara a tendência de o cultivar Rico 23 apresentar uma maturidade reprodutiva mais tardia que os demais, apenas pela 
QUADRO 1. Produção de matéria seca das flores e vagens do feijoeiro em g/vaso contendo cada um duas plantas. (Médias de 10 vasos)

\begin{tabular}{|c|c|c|c|c|c|c|c|}
\hline \multirow{2}{*}{ COLTIVARES } & \multicolumn{7}{|c|}{ DIAS APGS EMRRGEKCIA } \\
\hline & 40 & 50 & 40 & 50 & 60 & 70 & 80 \\
\hline & \multicolumn{2}{|c|}{---flores g-.-- } & \multicolumn{5}{|c|}{ 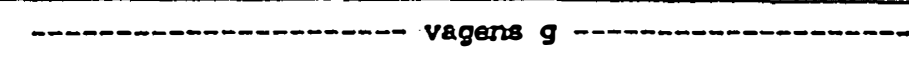 } \\
\hline Bico do Ouro & 0,45 & 0,07 & -- & 3,87 & 12,72 & 9,73 & 7,22 \\
\hline Carioca & 0,17 & 0,14 & - & 1,16 & 13,77 & 9,58 & 8,05 \\
\hline Goiano Precoce & 0,19 & -- & 0,61 & 6,20 & 4,75 & 3,19 & -- \\
\hline Rico 23 & 0,26 & 0,18 & -- & 0,52 & 6,42 & 8,34 & 7.74 \\
\hline Rosinha G2 & 0,16 & 0,22 & -- & 1,67 & 13,97 & 8,26 & 7,50 \\
\hline
\end{tabular}

QUADRO 2. Número médio de vagens e sementes por vaso contendo cada um duas plantas. (Médias de 10 vasos)

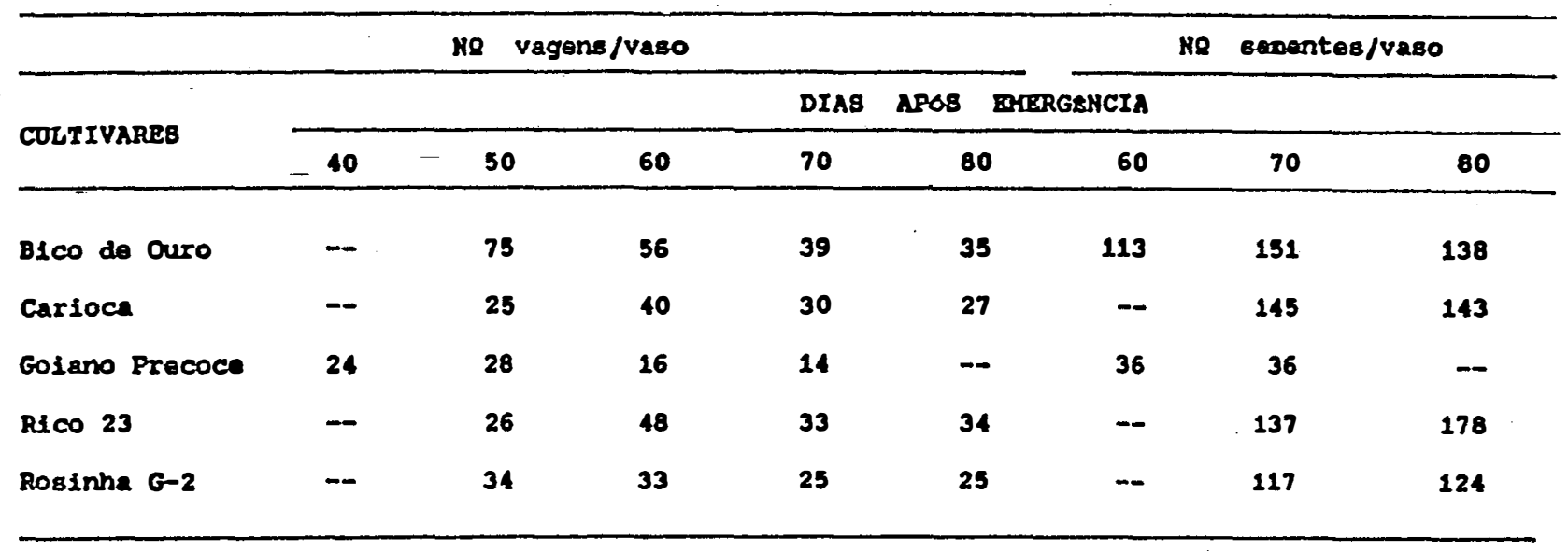


evolução da matéria seca destas partes, mesmo que o ciclo total da planta não fosse diferente dos demais.

Similarmente ao florescimento e produção de vagens, o àcúmulo de matéria seca nas sementes, figura 6, também define em parte o ciclo fisiológico interno das partes das plantas, confirmando que Rico 23 acumula matéria seca intensamente nas sementes no final de seu ciclo, entre 70 e 80 dias enquanto que em Carioca e Rosinha este fato é menos intenso.

Nesta mesma linha de observação, Bico de Ouro mostrou-se o mais precoce entre os cultivares do tipo III, com acúmulo intenso de matéria seca nas sementes entre os 60 e 70 dias após a emergência, porém sem atingir a maturação. completa antes que os demais cultivares.

Na figura 7, são apresentados os valores totais de matéria seca acumulada pelos cinco cultivares de feijão testados. Pelo seu ciclo mais curto, já aos 50 dias após a emergência, Goiano Precoce estabilizou seu crescimento em matéria seça, que manteve.valores praticamente constantes até a maturação completa. Provavelmente não se observou redução acentuada neste parâmetro em função de seu baixo índice de colheita, quadro 4, mostrando uma elevada produção de "palha". Rico 23 mostrou tendência semelhante a esta, porém em níveis absolutos bem mais elevados. Neste caso, além da permanência da palha, há que se considerar o fato de ser o ciclo reprodutivo, e o acúmulo de matérià seca' neste cultivar mais tardio que os demais, o que pode ter favorecido esta tendência, além de um índice de colheita que 


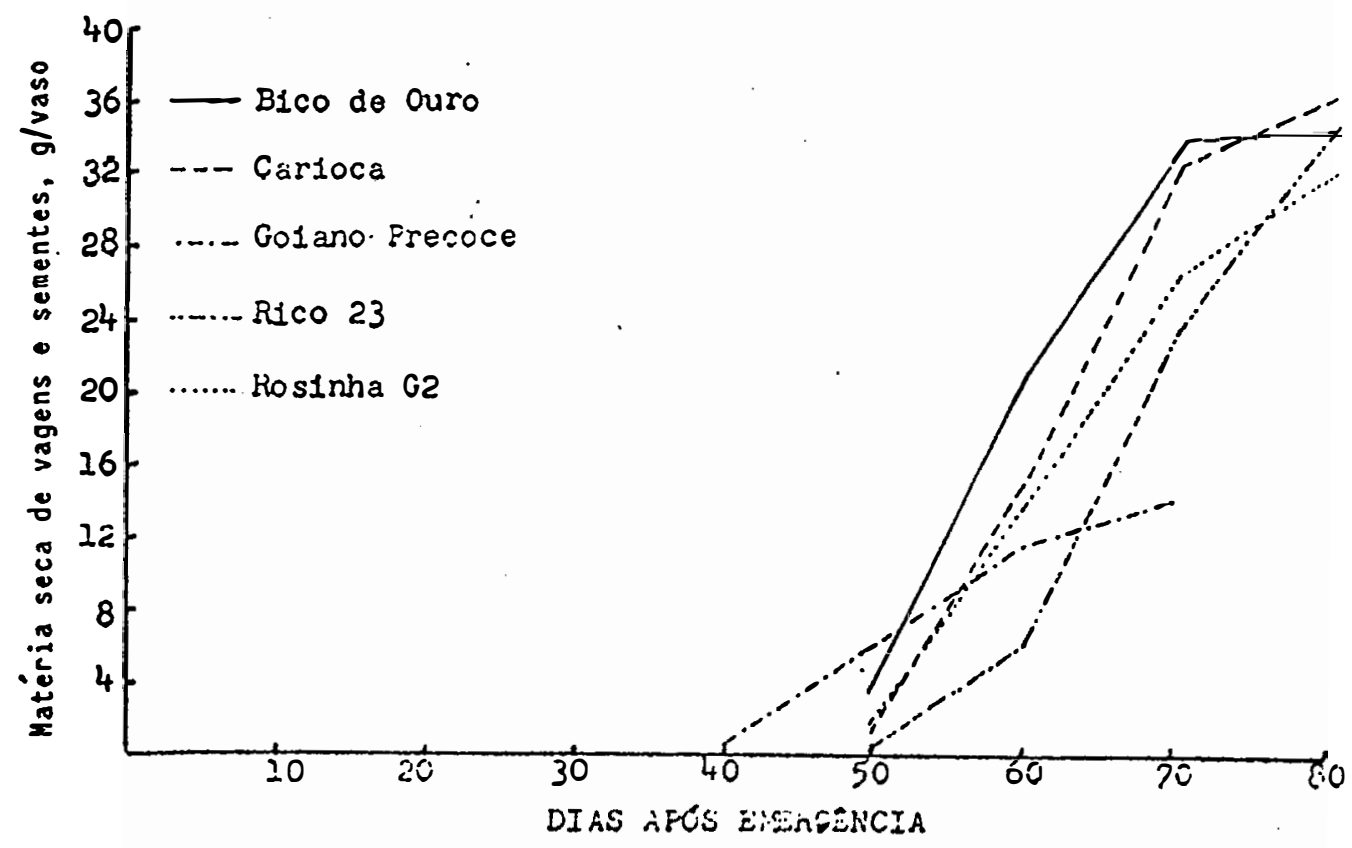

FIGURA 6. Produção de matéria seca das partes reprodutivas (vagens + sementes do feijoeiro, em g/vaso, contendo cada um duas plantas) média de 10 vasos. 
não se destacou dos demais estimados. Deve-se considerar que o acúmulo de matéria seca, para os cultivares de hábitos II e III testados deu-se até praticamente o final do ciclo demonstrando crescimento de matéria seca destinada preferencialmente às partes reprodutivas quando há muito já tinha ocorrido redução na participação das partes vegetativas.

Rosinha G2 e Carioca foram os cultivares que apresentaram maior altura, sendo os valores máximos atingidos aos 50 e 60 dias após a emergência com 156 e 184 cm respectivamente. Os cultivares Bico de Ouro e Rico 23 apresentaram 119 e $92 \mathrm{~cm}$ no mesmo período e o cultivar Goiano Precoce $42 \mathrm{~cm}$ aos 50 dias após a germinação. Conforme se observa na figura 8 todos os cultivares apresentaram um crescimento lento em altura até o $20^{\circ}$ dia após a germinação e ao final do ciclo, quando da maturação, há uma diminuição não muito acentuada. A altura das plantas no feijoeiro pode estar relacionada com a produção de grãos uma vez que ambas podem ser função do número de nós, ou posições para partes reprodutivas, quanto maior o número de nós mais posições e, por conseqüência, maior altura. Esta, por óbvio dependë também do alongamento dos entre-nós, que já apresenta uma relação intensa com o ambiente (luz, temperatura e umidade), conforme já mostrado por EMERSON (1916).

Na figura 9 estão representados os valores de número de folhas obtidas nas diversas idades das plantas. Os maiores valores foram observados para o cultivar Rico 23, que os apresentou bem mais elevados que os demais entre os 40 e 80 dias 


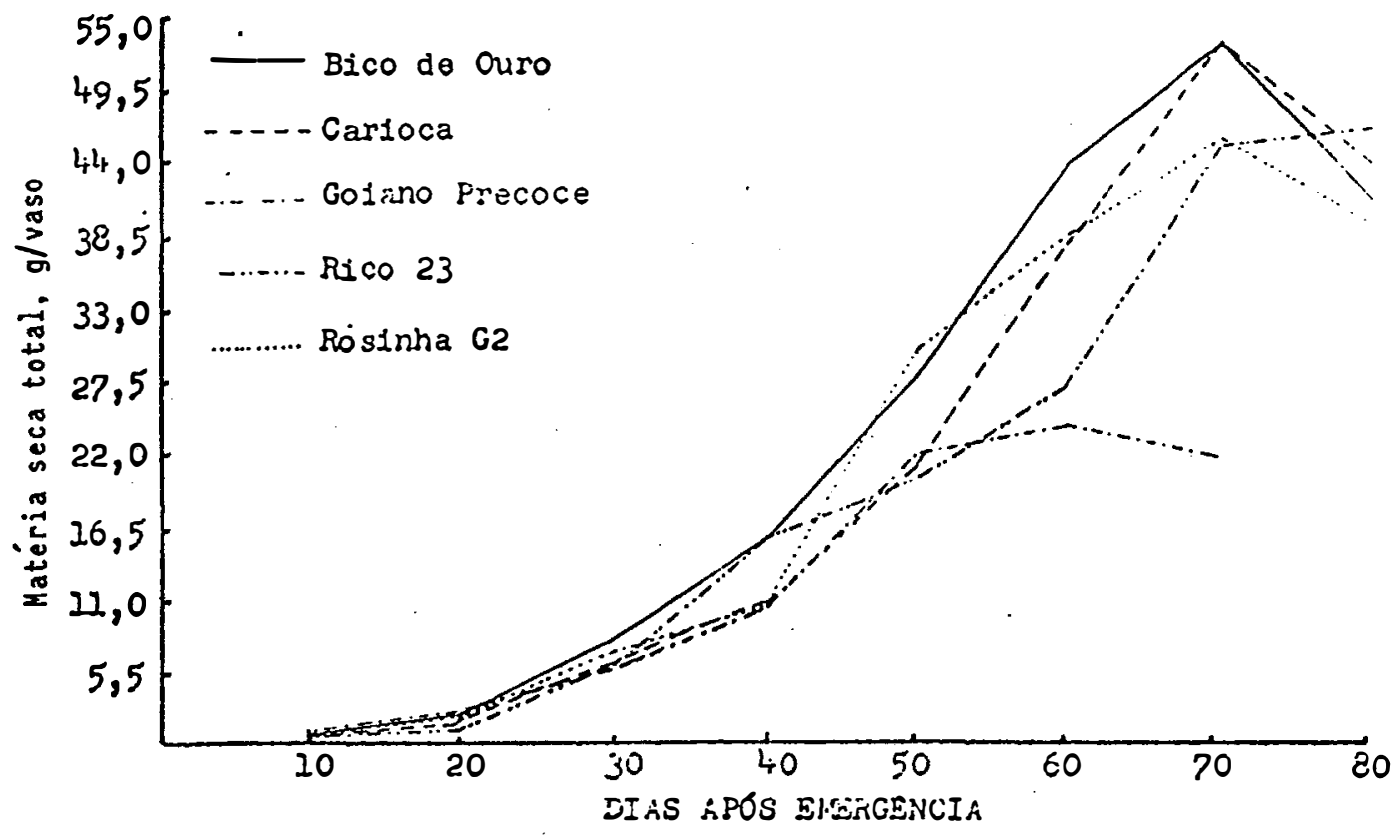

FIGURA 7. Produção total de matéria seca pelo feijoeiro em g/vaso contendo cada um duas plantas (média de 10 vasos). 


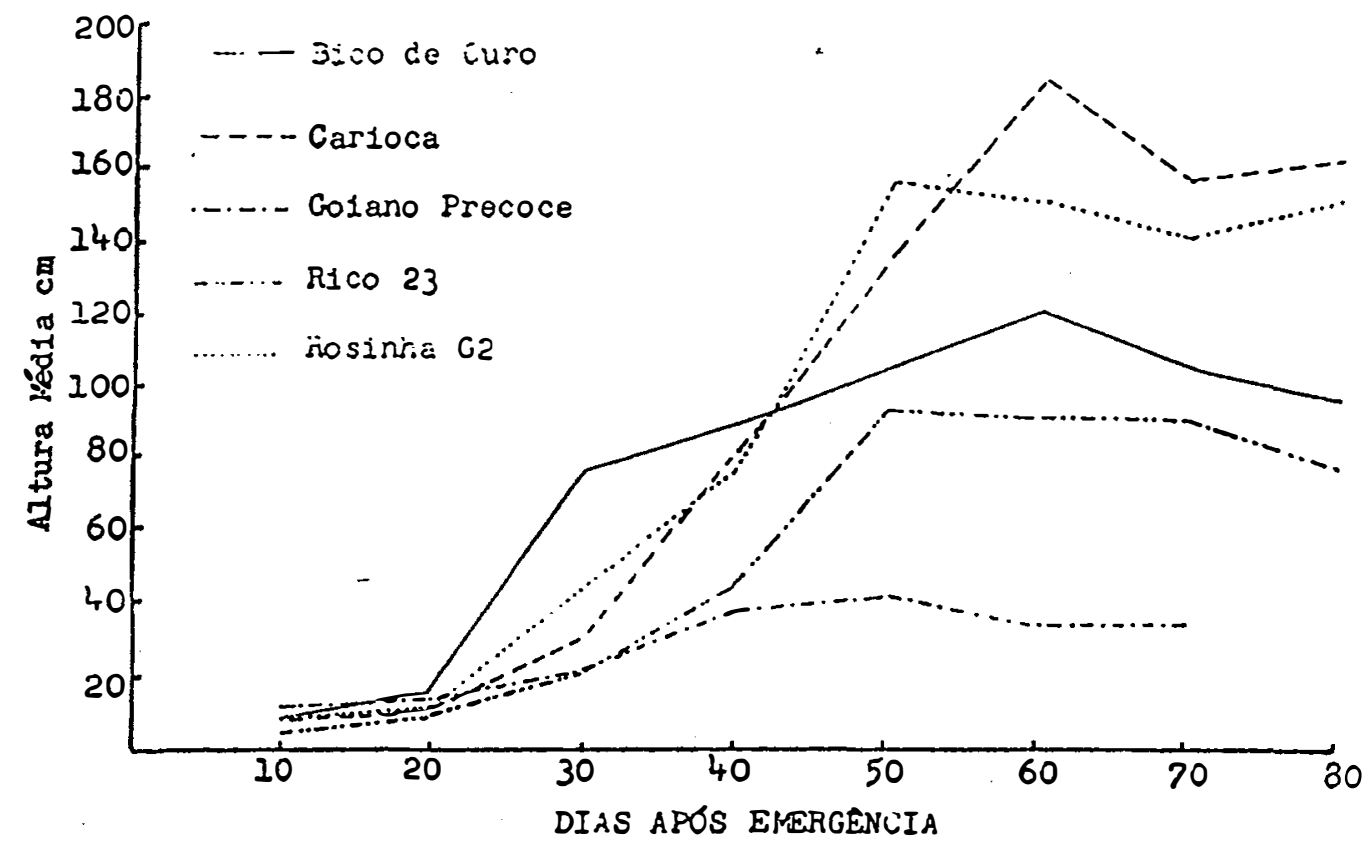

FIGURA 8. Altura média das plantas de feijoeiro em cm, (média de 10 vasos). 
após a germinação, já o cultivar Goiano Precoce apresentou menores valores, praticamente a metade dos demais. Além da altura o número de nós determina também o número de folhas, uma vez que estas estruturas neles se formam, havendo então relação estreita entre eles, ao menos até antes do período de maturação, quando ocorre senescência e queda de folhas. O maior número de folhas foi atingido entre 40 e 50 dias após a emergência, mantendo-se relativamente estável até os 60-70 dias, havendo uma queda abrupta ao final do ciclo, sendo pequeno o número delas quando as plantas findavam a maturação. Estas observações não concordam com aquelas de DUARTE e ADAMS (1972) onde havia uma correlação estreita entre número de folhas com o número de vagens, parece que ela só é válida para casos extremos de comparação como no do Goiano Precoce.

Conforme se observa na figura 10, os maiores valores de área foliar para os cultivares Goiano Precoce, Rico 23 e Rosinha G2 foram determinados aos 50 dias após a emergência, sendo que aos 60 dias são observados os maiores valores para os cultivares Carioca e Bico de Ouro. Há um crescimento acentuado na área foliar a partir do $20^{\circ}$ dia, acompanhando a tendência geral do crescimento das plantas, e para os cultivares mais tardios observase uma queda abrupta no final do ciclo, quando as plantas apresentam-se quase desfoliadas. Goiano Precoce a partir do $30^{\circ}$ dia mostrou valores menores que os demais, ao redor de 30\%inferiores, exceto com relação a 'Carioca' aos 50 dias após emergência. 


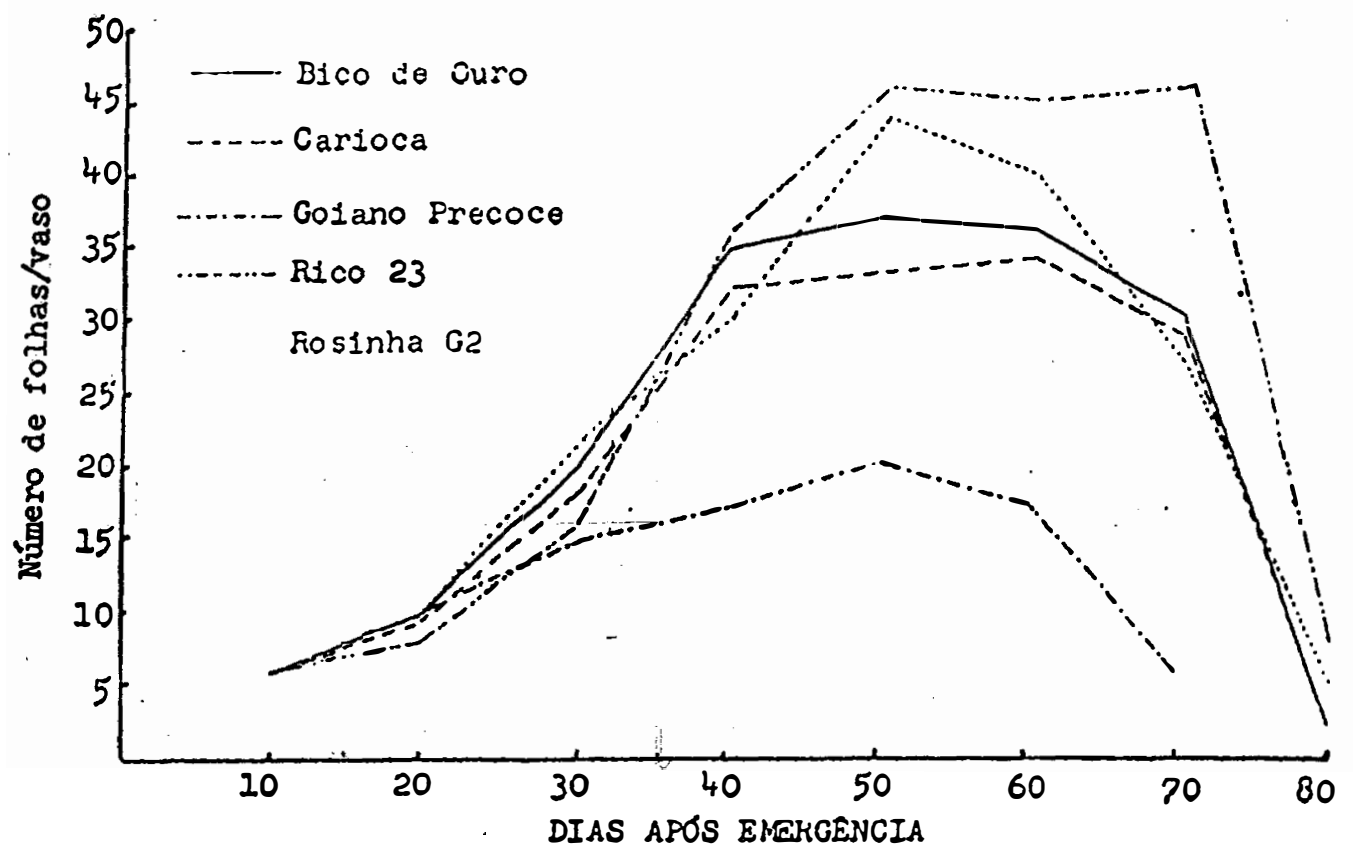

FIGURA 9. Número de folhas do feijoeiro, por vaso, contendo cada um duas plantas (média de 10 vasos). 


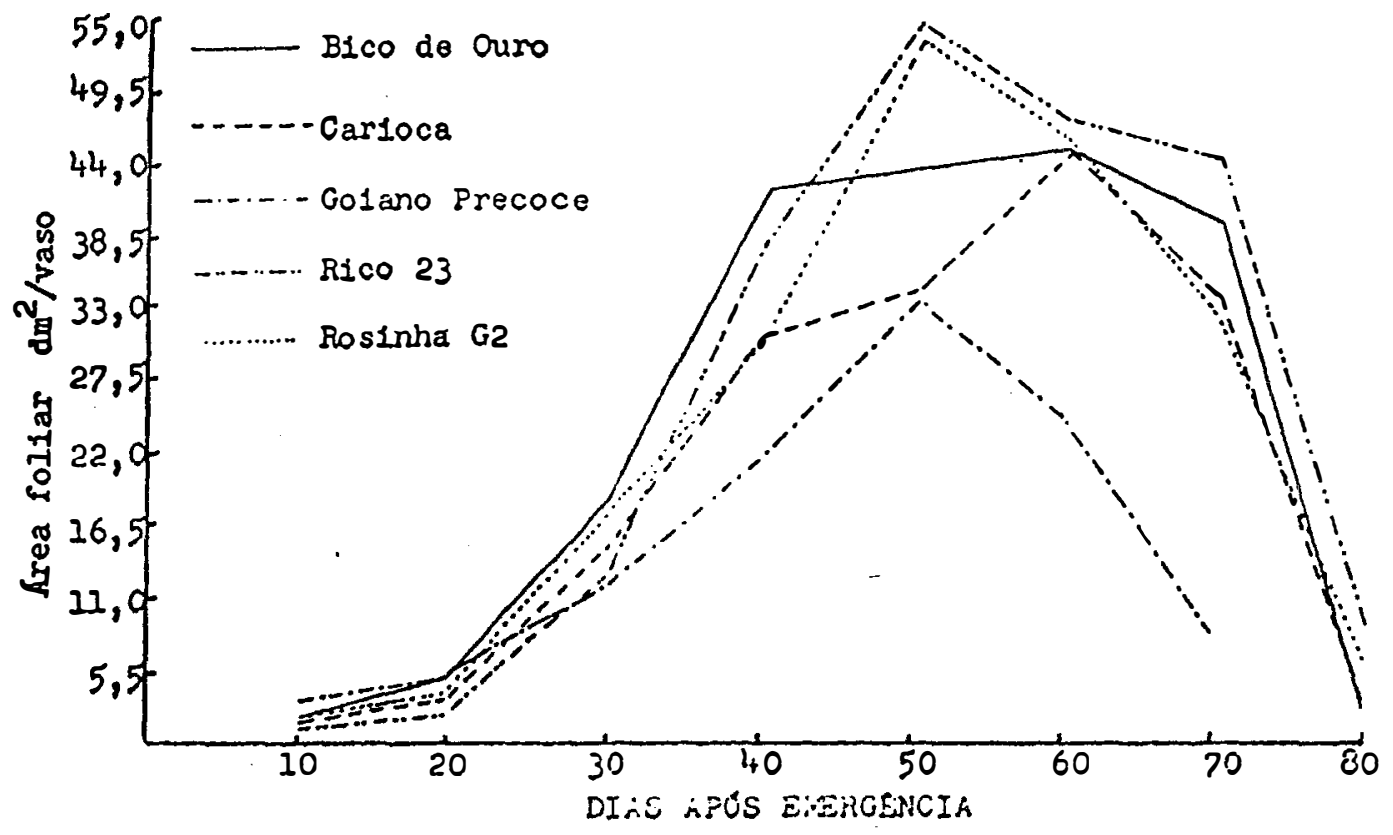

FIGURA 10. Área foliar do feijoeiro, em $\mathrm{dm}^{2}$ por vaso, contendo cada um duas plantas (média de 10 vasos). 
Com o avançar da idade das plantas a contribuição das folhas novas e pequenas vai se reduzindo na composição da área foliar, figura 11, observando-se então um incremento constante na área média de uma folha do início para o final do ciclo das plantas. No contexto dos cultivares testados, Goiano Precoce é sem dúvida o cultivar que apresentou os maiores valores para área foliar média, principalmente nas fases iniciais do ciclo, e no período que foi dos 40 aos 60 dias após a emergência. Por outro lado, Rico 23 foi o cultivar que apresentou, no geral menores folhas. Para que este cultivar apresentasse a maior área foliar, teria consentâneamente o maior número de folhas especialmente no período entre 40 e 80 dias após a emergência, conforme demonstrado na figura 9. E, dentro de certos limites pode-se considerar como válidas as correlações de DUARTE e ADAMS (1972) entre tamanho de folha e tamanho de sementes, confirmados principalmente, para a comparação Rico 23 e Goiano Precoce.

A relação entre a área foliar e a massa seca das folhas (área foliar específica), que estaria relacionada com sua espessura ou mesmo com fenômenos de translocação, é apresentada na figura 12. A maioria dos valores observados variou entre 3 e 4 $\mathrm{dm}^{2} / \mathrm{g}$. Nesta última fica clara a diferença entre cultivares, o que talvez expresse diferentes fases de seu ciclo quando das amostragens. Bico de Ouro, Carioca e Rosinha G2 apresentam um comportamento bastante similar até os 70 dias com um pico principal aos 40 dias e um secundário aos 60, após a emergência. O cultivar Rico 23 apresenta um único pico de valor elevado aos 50 dias com 


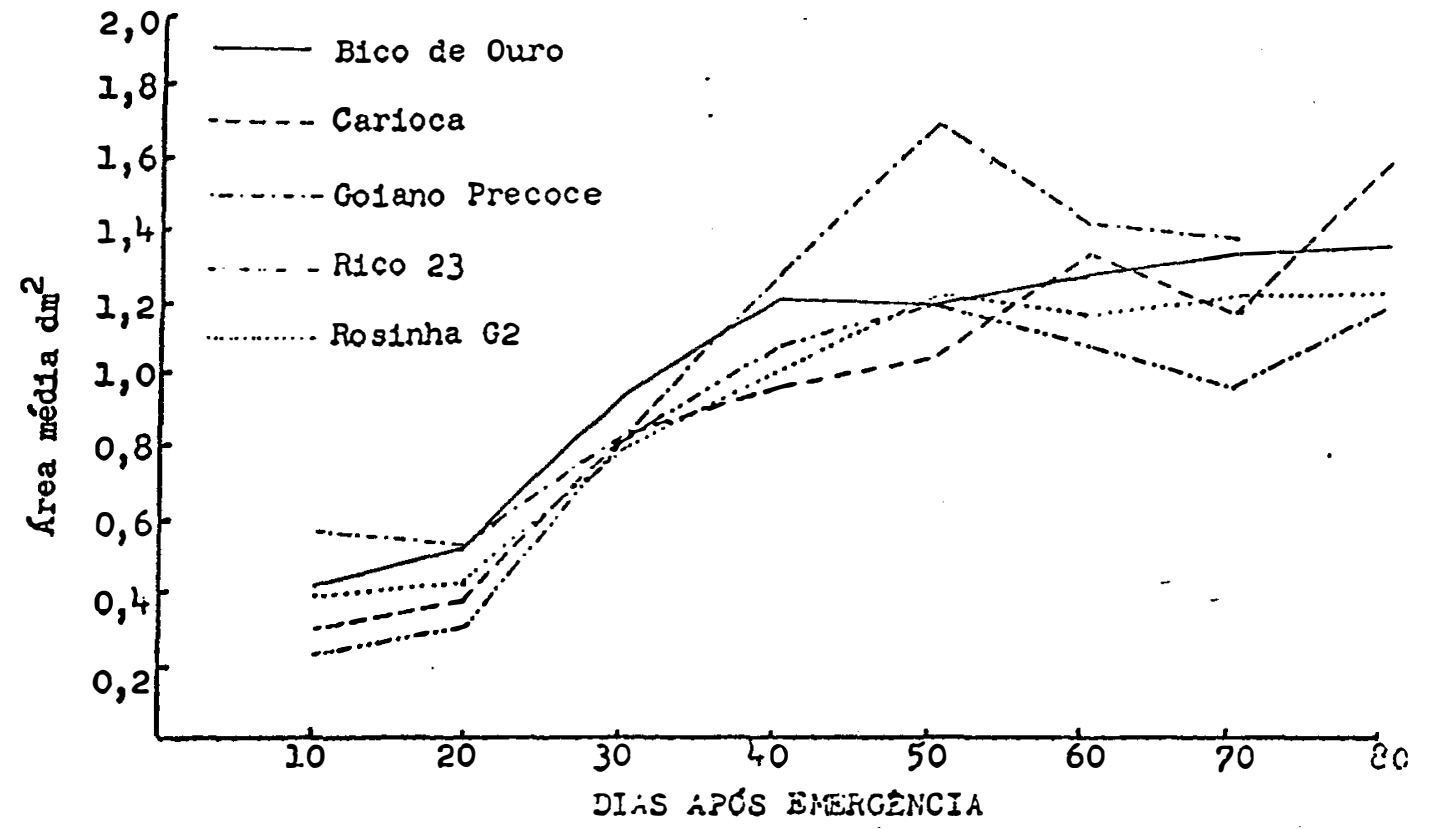

FIGURA 11. Área média das folhas de feijoeiro, em $\mathrm{dm}^{2}$. 
decréscimos equivalentes antes e após esta data. Carioca e Rosinha G2, apresentam tendência de elevação do valor da área foliar específica no final do ciclo. Estes picos observados podem ser considerados como períodos em que havia uma mais intensa expansão foliar, ou períodos em que ocorria uma translocação de fotossintetizados das folhas para os órgãos reprodutivos. 0 cultivar Goiano Precoce mostrou valores médios em relação aos demais cultivares, com tendência a valores mínimos para o final do ciclo como Rico 23 e Bico de Ouro. Aos 10 dias após a emergência, as folhas do feijoeiro Goiano Precoce apresentam uma massa específica de $25 \mathrm{~g} / \mathrm{m}^{2}$, menor que a dos demais, conforme ilustrado na figura 13. A ampliação da escala para gramas de folha por metro quadrado de tecido foliar mostra que os cultivares Goiano Precoce e Rico 23, no período entre 30 e 70 dias após a emergência têm um comportamento bastante similar com quanto às relações de expansão foliar e sua massa, provavelmente residindo no seu hábito de crescimento, tipos I e II respectivamente, a coincidência de seus fluxos de crescimento, mesmo que as intensidades sejam diferentes.

O cultivar Bico de Ouro emitiu um número de vagens muito mais elevado que os demais cultivares, representando provavelmente um florescimento mais abundante e concentrado entre os 40 e 50 dias após a germinação, quadro 2 e figura 14. Os valores iniciais de 75 vagens por vaso foram se reduzindo paulatinamente 


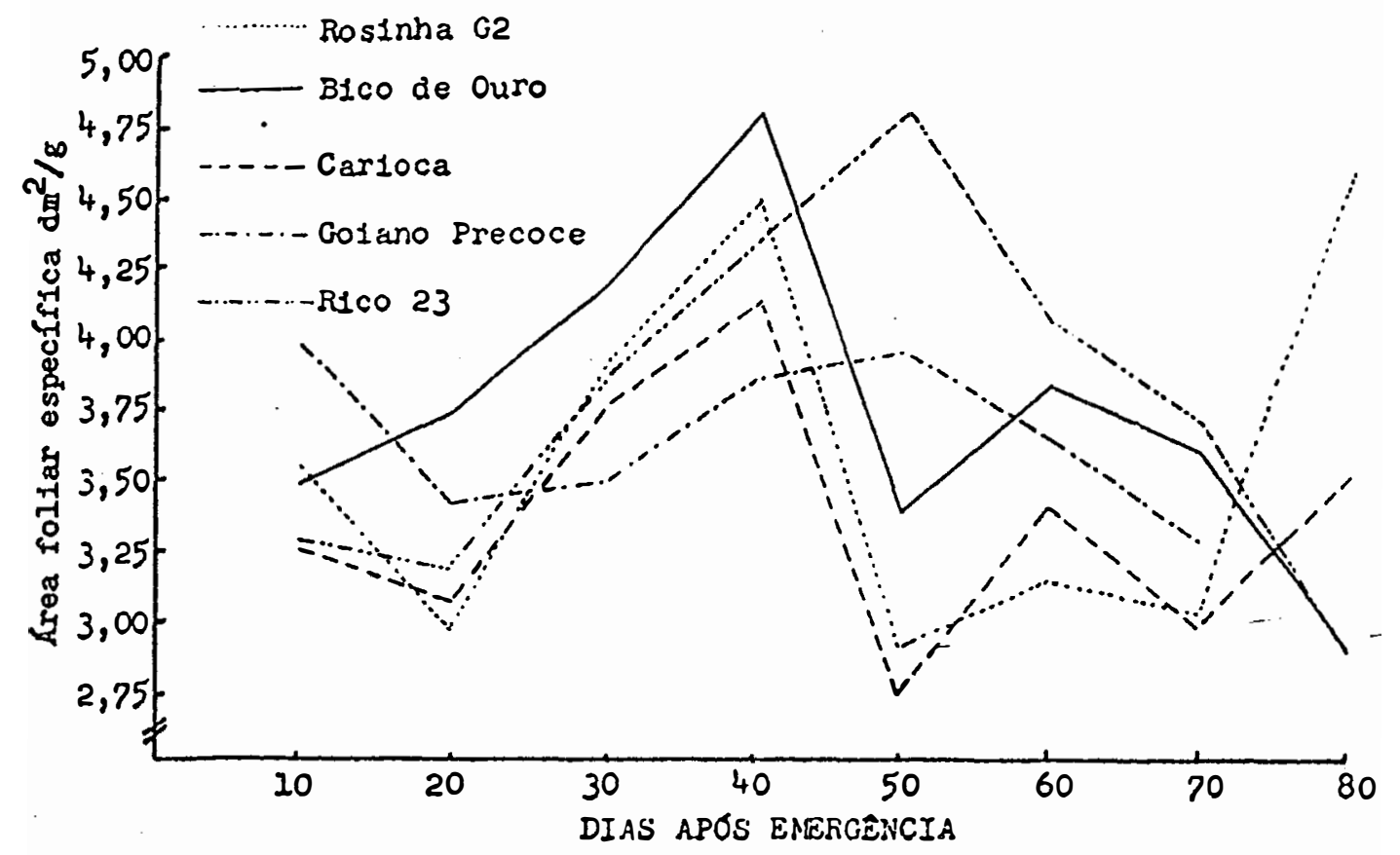

FIGURA 12. Área foliar específica do feijoeiro em $\mathrm{dm}^{2}$. (Médias de 10 vasos). 


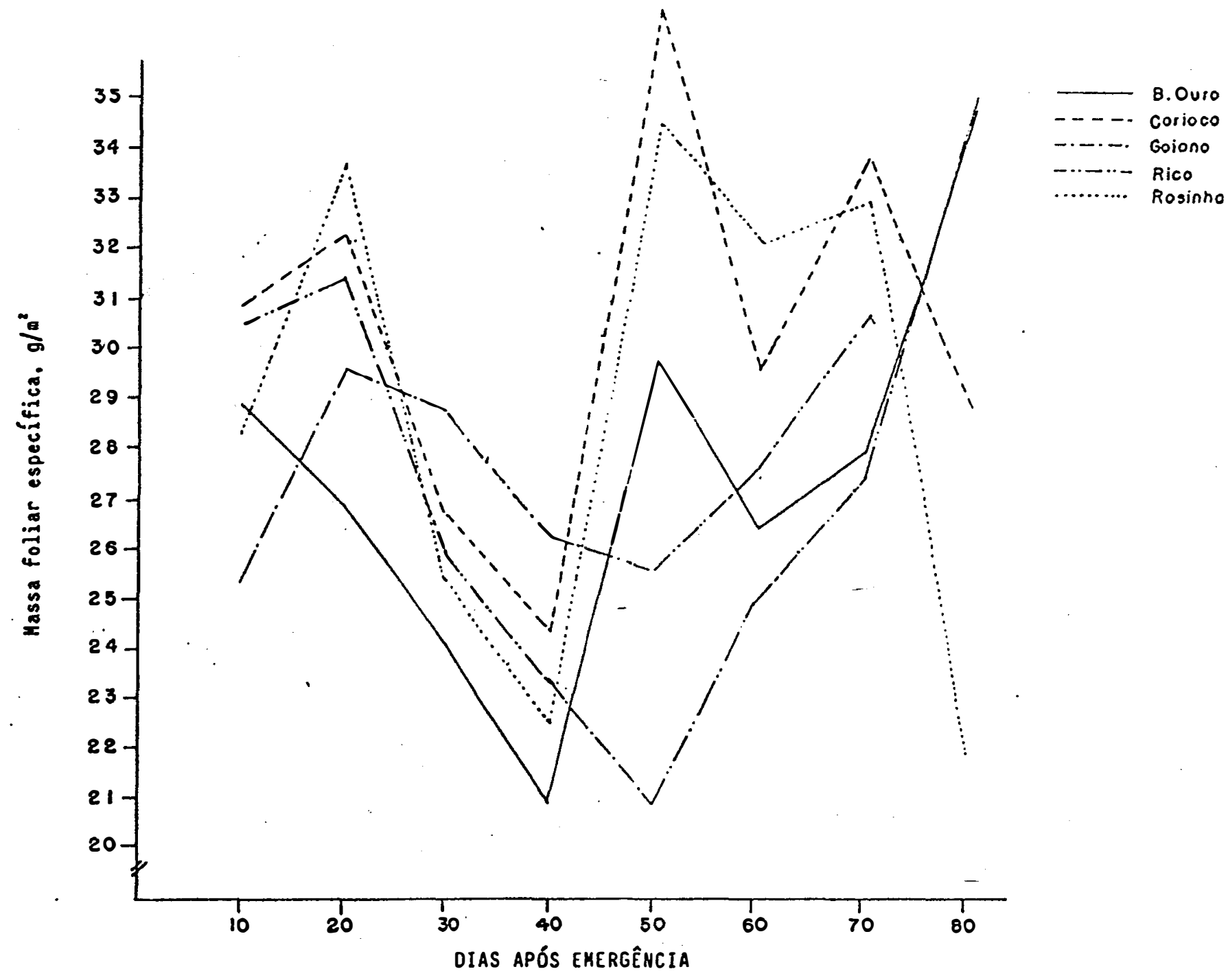

FIGURA 13. Massa foliar específica $\mathrm{g} / \mathrm{m}^{2}$. 
até o valor final de 35 vagens/vaso, sempre superior aos valores dos demais cultivares. Rico 23 e Carioca mostraram comportamento semelhante entre si, com menor número de vagens aos 50 dias, maior aos 60 e uma redução posterior. O cultivar Goiano Precoce apresentou tendência semelhante a esta, porém com 10 dias de antecedência e valores absolutos mais baixos. Pode-se claramente verificar que o feijoeiro emite muito mais vagens do que consegue nutrir, havendo mecanismo de aborto de vagens imaturas que são eliminadas para garantia do pleno preenchimento das restantes, o que acrescenta mais um mecanismo de controle do pegamento de vagens além dos ambientais propostos por LAMBERTH (1950). Goiano Precoce, significativamente apresentou o menor número de vagens por vaso, de sementes/vaso, de sementes/vagem (quadro 2), que mesmo compensado por um peso de sementes praticamente 50 a $100 \%$ maior que os demais ainda redundou numa produtividade de matéria seca final de sementes muito menor que as demais, quadro 4. Rico 23 foi o cultivar que apresentou o maior número de sementes/vaso, porém suas sementes foram menores que as demais $(15,1 \mathrm{~g} / 100$ sementes), havendo portanto um bom efeito de compensação, sendo a produtividade final de sementes dele semelhante à dos cultivares de crescimento tipo III. Considerando-se uma população ideal de $200 \mathrm{mil}$ plantas por hectare foram obtidos os valores de produção de matéria seca, expostas no quadro 3. Raízes e folhas, por ocasião da colheita, representam as menores parcelas da matéria seca e individualmente as sementes a maior, seguida pela palha das vagens e depois pelas hastes. 


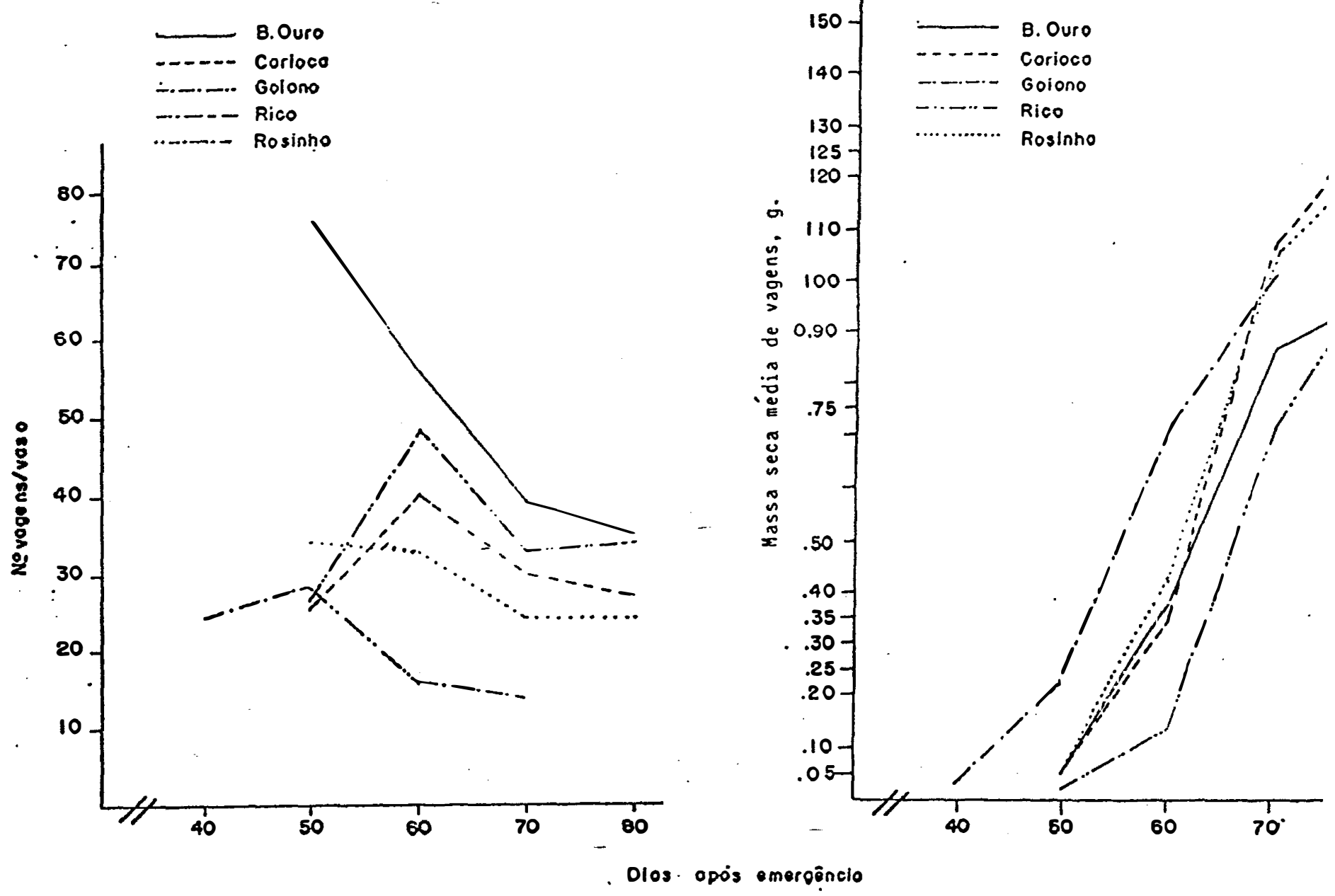

FIGURA 14. Número de vagens por vaso com 2 plantas e produção de massa seca média de uma vagem com as sementes. 
A produção de sementes apontada, entre aproximadamente 2.500 e $2.800 \mathrm{~kg} / \mathrm{ha}$, para os quatro cultivares de ciclo mais longo pode ser considerada como adequada aos fins propostos e expressão do potencial produtivo dos mesmos. Como estamos trabalhando com matéria seca, provavelmente valores próximos a 10\% superiores seriam observados para tirar grãos em condições de produção. Assim, produtividades ao redor de 3.000 kg/ha para os cultivares Bico de Ouro, Carioca, Rico 23 e Rosinha G2 mostram que as plantas se desenvolveram em condições não limitantes a seu crescimento. Apenas Goiano Precoce, mostrou produção de grãos que pode ser considerada um pouco abaixo do que seria de se esperar, apesar de a planta ter apresentado crescimento satisfatório, quadro 3. Parte da explicação para o pior desempenho produtivo deste cultivar pode ser visto no quadro 4, onde verificase que seu índice de colheita foi significativamente inferior ao dos demais cultivares, indicando uma baixa eficiência de transferência de fotossintetizados para as sementes. Quanto a esta medida, Rosinha G2 e Rico 23 também apresentaram valores intermediários, significativamente menores que Bico de ouro e Carioca, se bem que Rico 23 também não diferisse significativamente dos dois já citados. Assim, o Índice de colheita apontado no quadro 4, é fator a se considerar na definição da produtividade do feijoeiro, pois crescimentos equivalentes entre cultivares, ou 
QUADRO 3.Produção de matéria seca em $\mathrm{kg} / \mathrm{ha}$ pelas diversas partes da planta, no final do ciclo do feijoeiro, considerandose uma população ideal de 200.000 plantas/ha. (Média de 10 vasos)

\begin{tabular}{|c|c|c|c|c|c|c|}
\hline COLTIVAREB & $R A \pm Z B B$ & HASTES & FOLHAS & VAGENS & 8EH. & TOTAL \\
\hline & $\cdots-\cdots$ & -- & $m-\infty$ & he $-\cdots$ & $-\cdots$ & 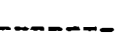 \\
\hline Bico de Ouro & 154 & 429 & 92 & 722 & 2690 & 4087 \\
\hline Carioca & 208 & 458 & 90 & 805 & 2807 & 4368 \\
\hline Golano Precoce & 225 & 269 & 250 & 319 & 1090 & 2153 \\
\hline $\operatorname{RicO} 23$ & 253 & 566 & 321 & 774 & 2615 & 4599 \\
\hline Rosinha 62 & 157 & 410 & 132 & 750 & 2436 & 3885 \\
\hline
\end{tabular}

QUADRO 4. Indices fisiológicos médios determinados nas plantas de feijoeiro na última amostragem (Colheita).

\begin{tabular}{|c|c|c|c|c|c|c|c|}
\hline COLTIVARE8 & $\begin{array}{l}\text { lat. seca } \\
\text { total }\end{array}$ & $\begin{array}{l}\text { Mat. seca } \\
\text { som. }\end{array}$ & $\begin{array}{l}\text { Indice de } \\
\text { colheita }\end{array}$ & $\begin{array}{l}\text { HQ de } \\
\text { vagen }\end{array}$ & $\begin{array}{l}\text { Ke de } \\
\text { Bex. }\end{array}$ & $\begin{array}{l}\text { Me de } \\
\text { sen.l } \\
\text { fvagen }\end{array}$ & $\begin{array}{r}\text { Peso adio } \\
100 \text { serentes }\end{array}$ \\
\hline & $\mathbf{g}$ & $\boldsymbol{g}$ & 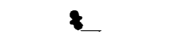 & & & & $\mathbf{g}$ \\
\hline Bico de ouro & $40,87 a$ & 26,902 & $66,27 a$ & $35,3 a$ & $138,2 \mathrm{~b}$ & $3,94 \mathrm{~b}$ & $19.5 \mathrm{~b}$ \\
\hline Carloca, & $43,67 a$ & 28,072 & $64,17 a$ & $27,2 \mathrm{~b}$ & $142,7 \mathrm{~b}$ & $5,26 a$ & $19.6 \mathrm{~b}$ \\
\hline Goiano Precoce & $21,52 b$ & $10,91 \mathrm{~b}$ & $50,43 \quad c$ & $14,4 \mathrm{C}$ & $36,3 \mathrm{c}$ & $2,51 \mathrm{c}$ & $30,3 a$ \\
\hline Rico 23 & $45,99 a$ & $26,86 a$ & $62,41 a b$ & $34,3 a$ & $178,4 a$ & $5,19 a$ & $15,1 \mathrm{c}$ \\
\hline Rosinha 62 & $38,85 a$ & $24,36 a$ & $57,88 \mathrm{~b}$ & $25,4 \mathrm{~b}$ & $124,1 \mathrm{~b}$ & $4,92 a$ & 19,6 b \\
\hline Modia & 38,18 & 23,42 & 60,24 & 27,3 & 123,9 & 4,36 & 20,8 \\
\hline Tukey 58 & 8,72 & 6,36 & 2,73 & 6,2 & 30,3 & 0,69 & 2,5 \\
\hline c.v. & 17,9 & 21,3 & 4,2 & 17,7 & 19,2 & 12,5 & 9,4 \\
\hline
\end{tabular}

Indices literais idênticos apresentam tratamentos semelhantes pelo teste de Tukey a 58 . 
adequados para determinada condição ambiental podem redundar em produtividades mais baixas, pela menor eficiência de acúmulo de matéria seca nas sementes. Então, o menor índice de colheita pode ajudar a explicar por que Goiano Precoce, apesar de menor número de sementes porém com sementes muito maiores não conseguiu estabelecer uma compensação que elevasse sua produtividade ao nível dos demais cultivares estudados.

O cultivar Rosinha G2, também apresentou um índice de colheita relativamente baixo em relação aos demais cultivares, exceto Goiano Precoce, e também mostrou produtividade menor que os demais, porém não significativamente. A avaliação dos componentes de produção: número de vagens, número de sementes por vagem e peso médio das sementes, mostra bem o grau de relação existente entre eles e a produtividade. Bico de Ouro e Rico 23 mostraram maior número de vagens, Carioca, Rico 23 e Rosinha 62 maior número de sementes por vagem e Bico de Ouro, Carioca e Rosinha G2 valores iguais de peso de sementes, enquanto que Rico 23 apresentou o menor valor, compensando outras vantagens. Estes dados estão de acordo com os discutidos por. WALLACE e MUNGER (1966) que consideram também fatores fisiológicos, mais o ambiente como determinantes da complexa produção econômica do feijoeiro.

As representações gráficas de acúmulo de matéria seca pelas diferentes partes da planta, nas diversas idades, para os cinco cultivares, e a sua distribuição percentual encontram-se nas figuras 15 a 24. Verifica-se claramente, em todas elas, que até - $40^{\circ}$ dia após a emergência para Goiano Precoce e até $050^{\circ}$ dia 
para os demais é acentuada a contribuição das folhas na formação da matéria seca total, a valores que flutuam ao redor de $60 \%$. As raízes, no período contribuem com valores ao redor de $30 \%$ as hastes com 10\%. Com o avançar da maturidade das plantas e com o aparecimento das partes reprodutivas, há uma redução na participação das partes vegetativas, assumindo papel preponderante as vagens e sementes.

o sistema radicular é o primeiro órgão a reduzir seu crescimento. Exceto para o cultivar Carioca não se observou acúmulo de matéria seca 40 a 50 dias após a emergência das plantas em todos os outros cultivares. As hastes mostram uma contribuição percentual na matéria seca praticamente constante durante o ciclo das plantas, porém, após o florescimento e quando são observadas as primeiras vagens, em todos os cultivares esta participação aumentou, demonstrando que, por um certo tempo as hastes comportamse como "armazéns" intermediários de fotossintetizados, que serão posteriormente direcionados ao seu local definitivo de estocagem, as sementes.

Quando da colheita, as vagens sem as sementes, "palha", correspondem a aproximadamente $20 \%$ da matéria seca presente na planta, independentemente do cultivar. Por outro lado, a contribuição das sementes na matéria seca durante a colheita varia com o cultivar e de maneira significativa, com Goiano Precoce mostrando valor ao redor de 50\%, Rico 23 ao redor de 57\% e os demais atingindo valores até $64 \%$, demonstrando que há uma nítida 


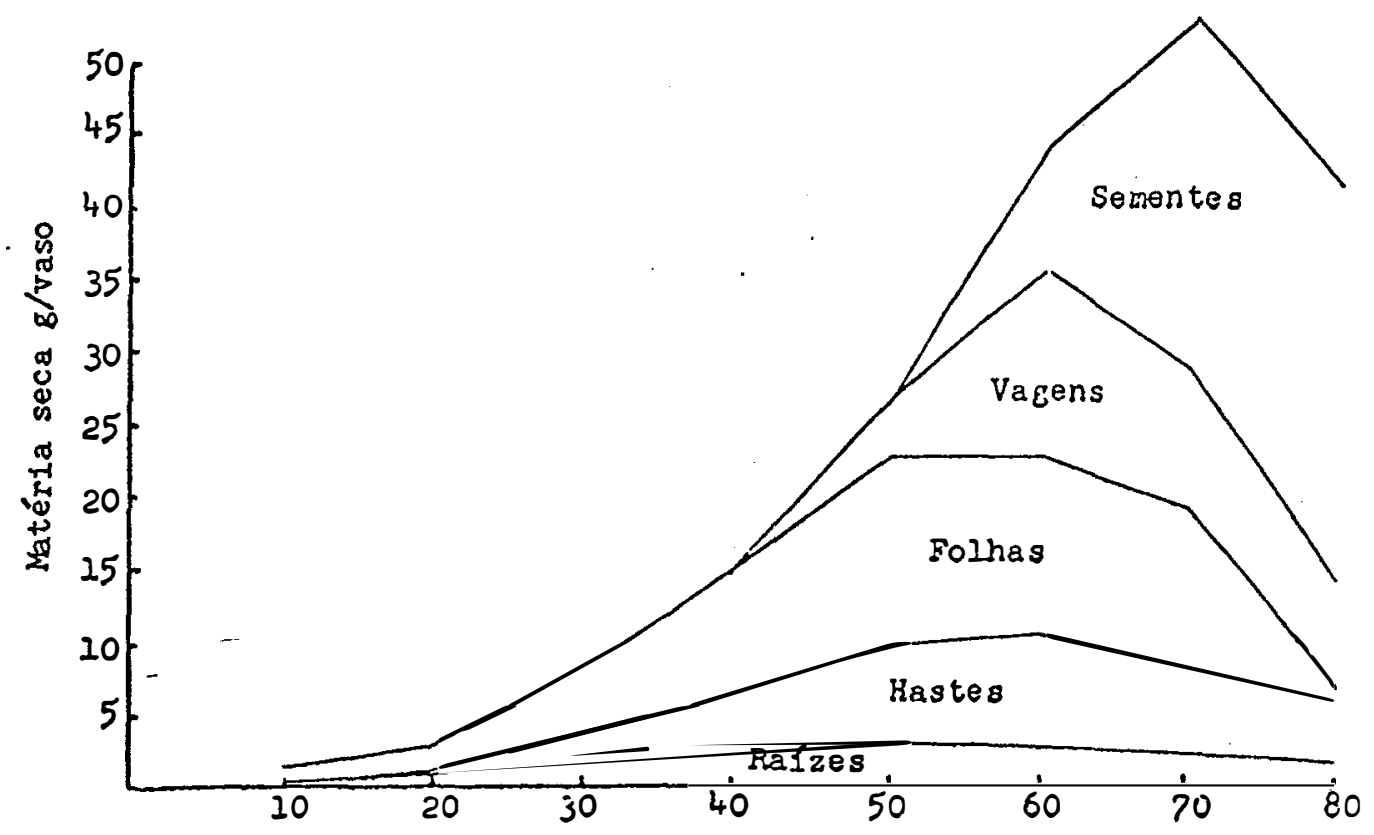

FIGURA 15. Distribuição da matéria seca nos diversos órgãos do feijoeiro cultivar Bico de Ouro, em g/vaso contendo cada um duas plantas. 


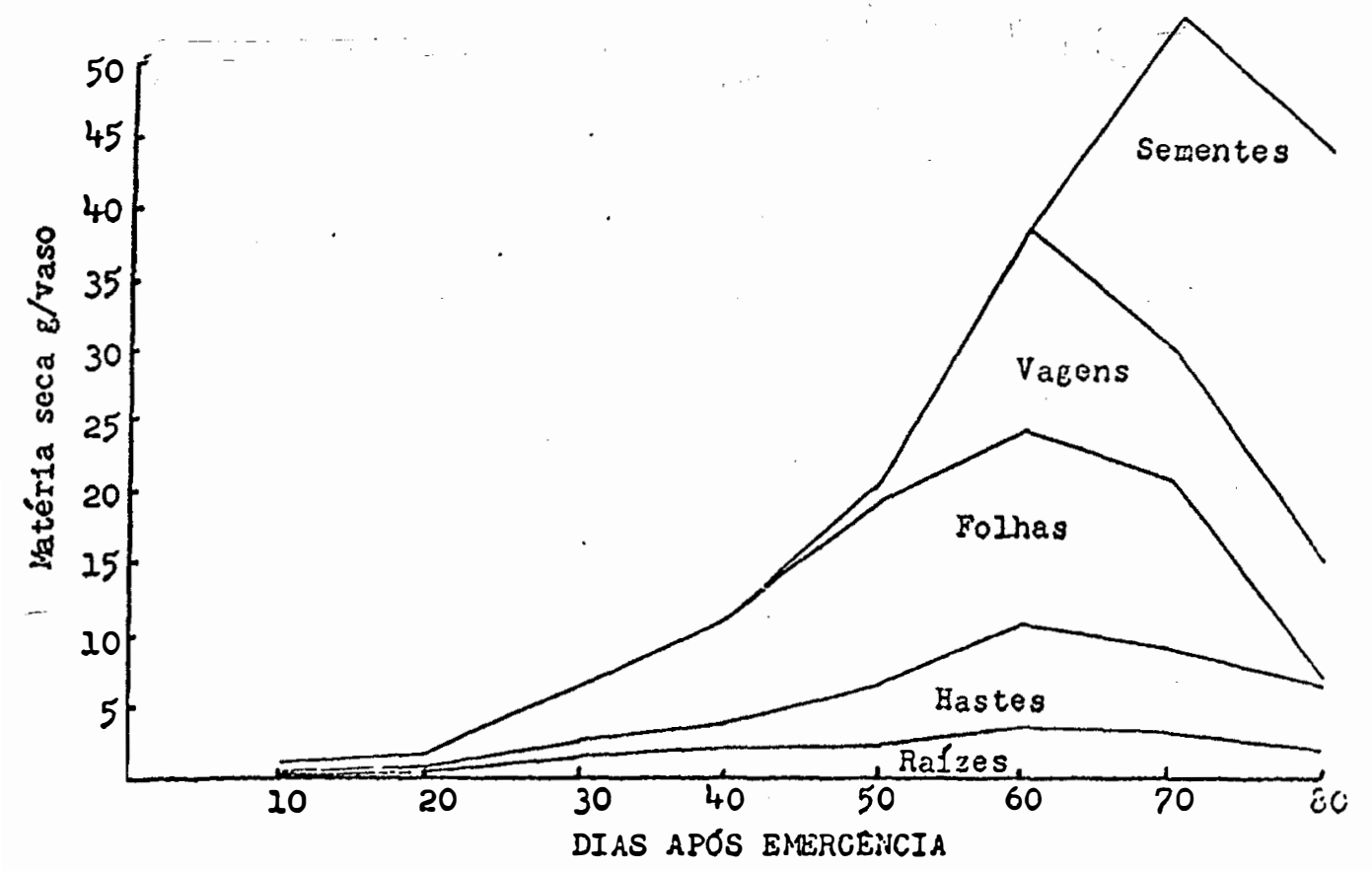

FIGURA 16. Distribuiç̃o da matéria seca nos diversos órgãos do feijoeiro cultivar Carioca, em g/vaso contendo cada um duas plantas. 


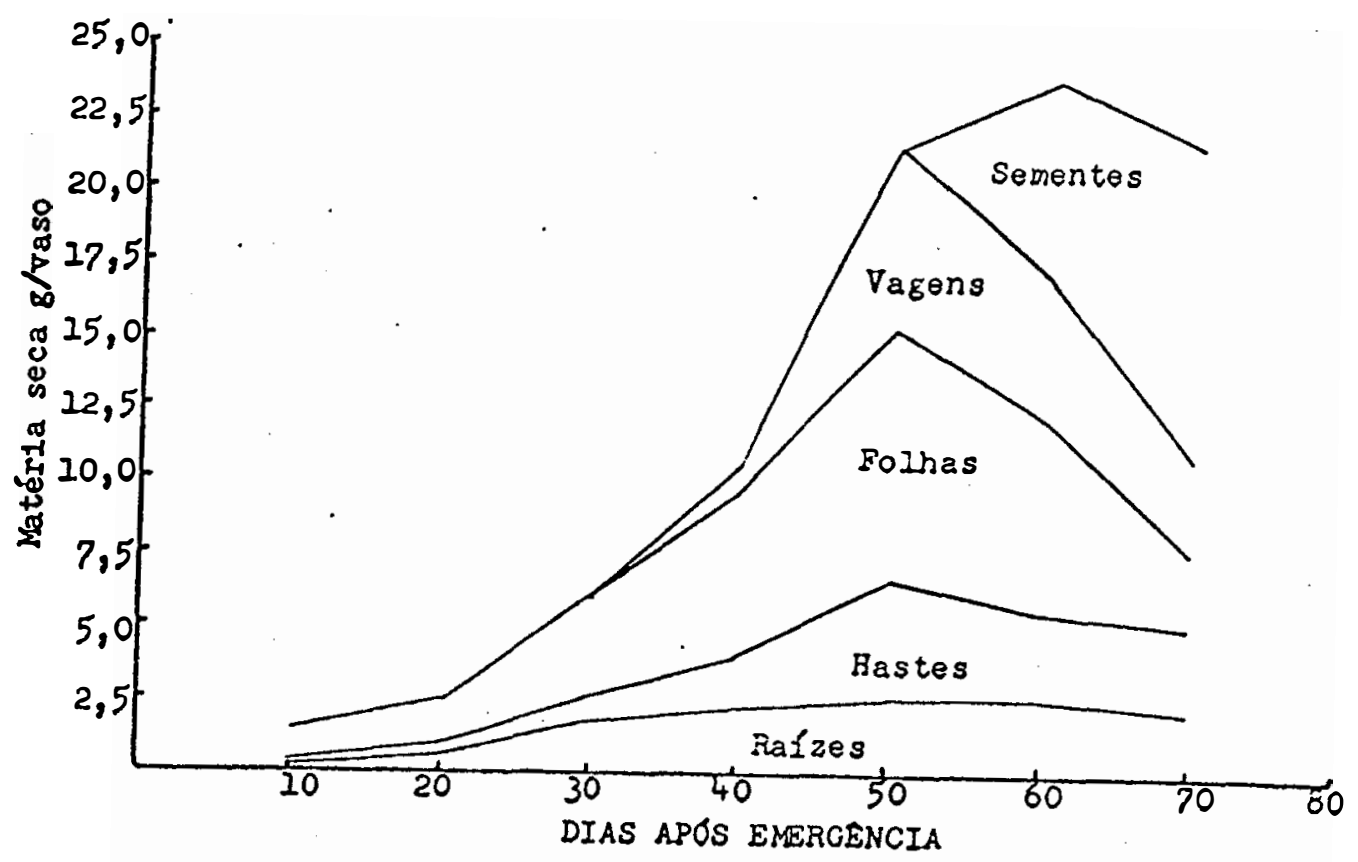

FIGURA 17. Distribuição da matéria seca nos diversos órgãos do feijoeiro cultivar Goiano Precoce, em g/vaso contendo cada um duas plantas. 


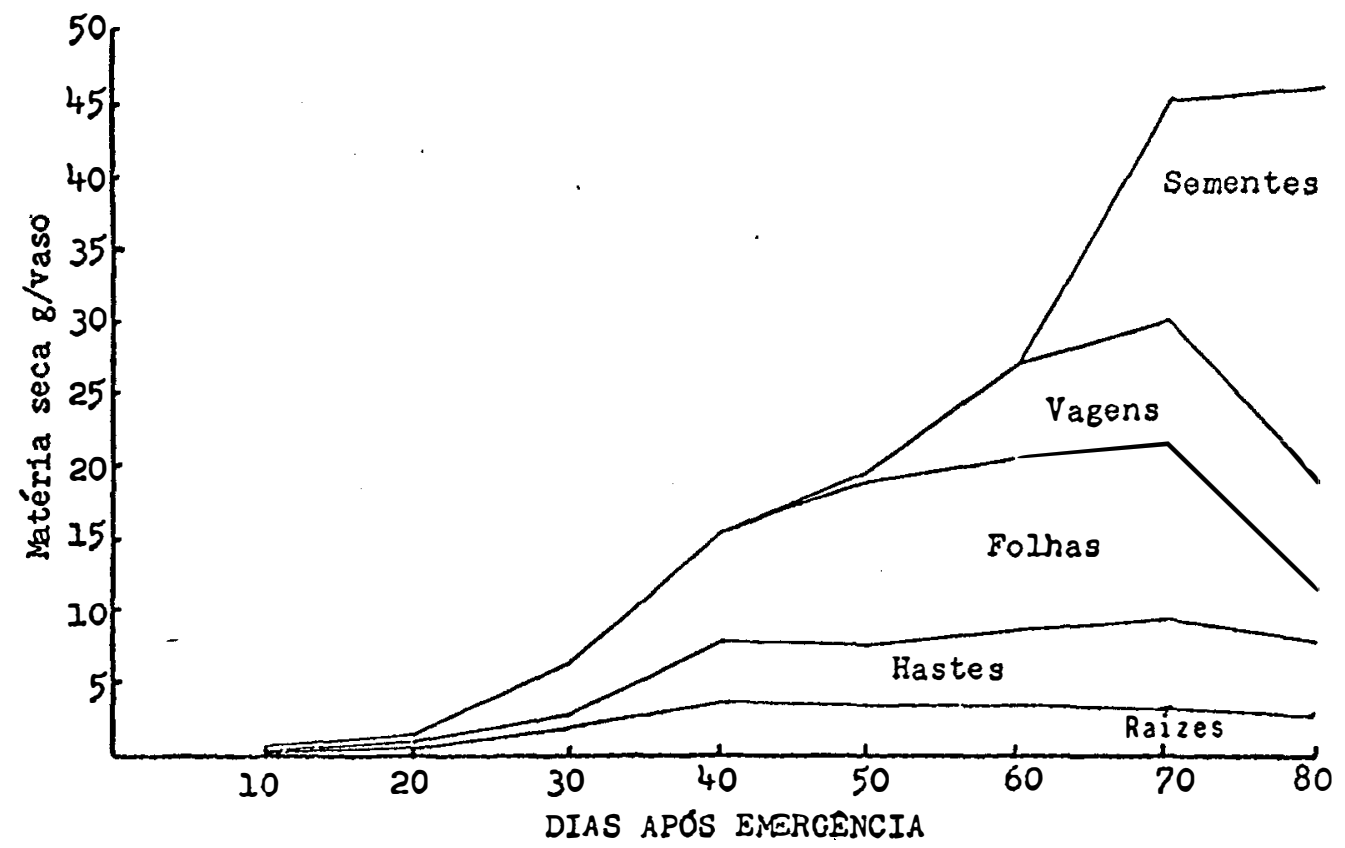

FIGURA 18. Distribuição da matéria seca nos diversos órgão do feijoeiro cultivar Rico 23, em g/vaso contendo cada um duas plantas. 


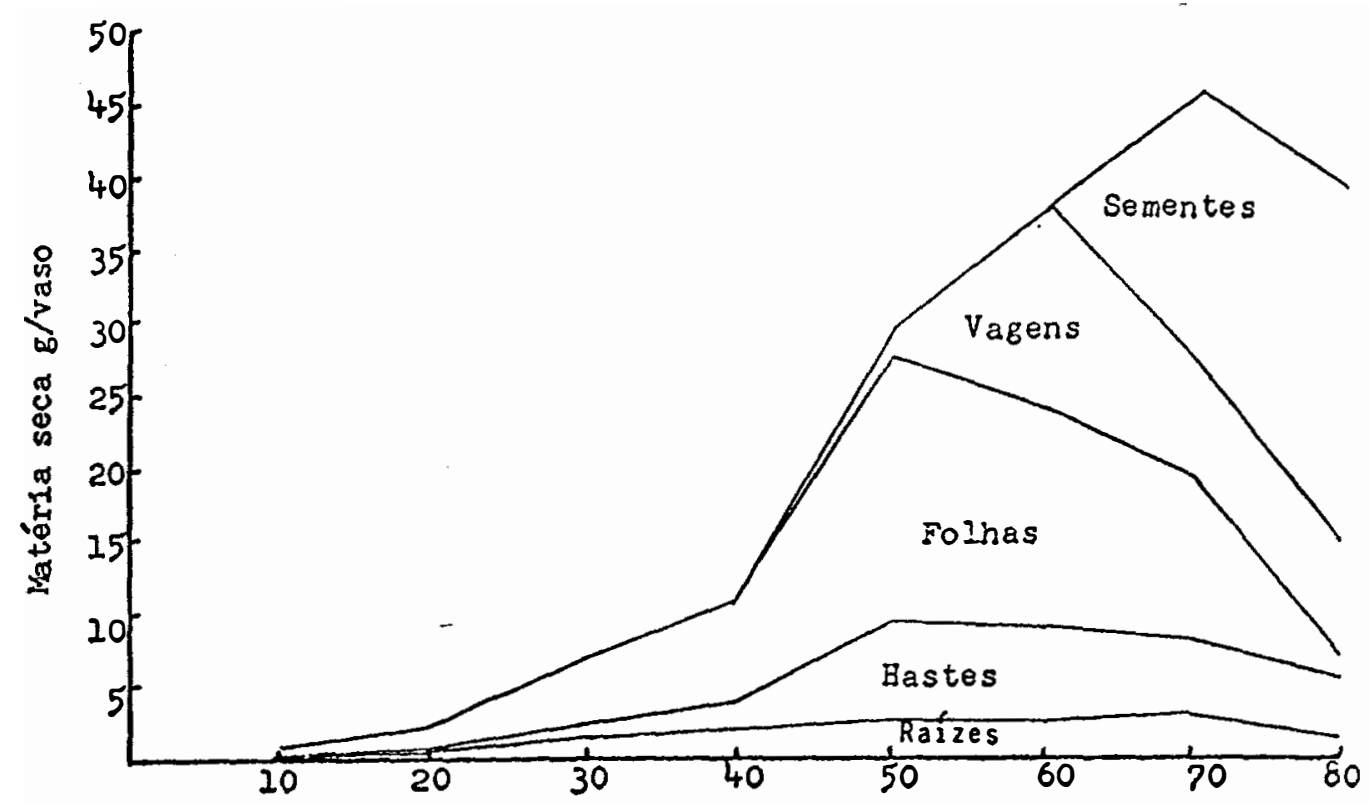

FIGURA 19. Distribuição da matéria seca nos diversos órgãos do feijoeiro cultivar Rosinha G2, em g/vaso contendo cada um duas plantas. 


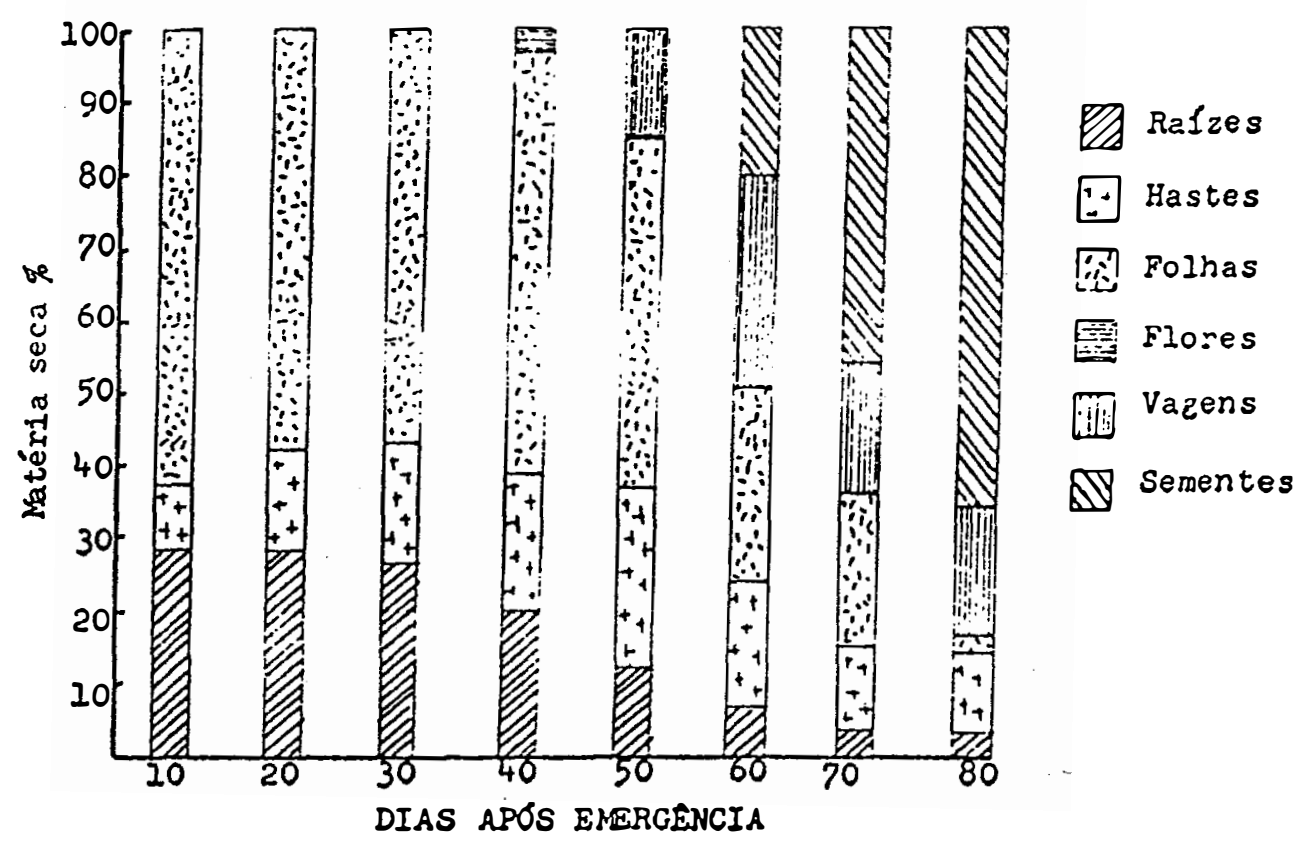

FIGURA 20. Distribuição percentual da matéria seca nos diversos órgãos do feijoeiro cultivar Bico de Ouro. 


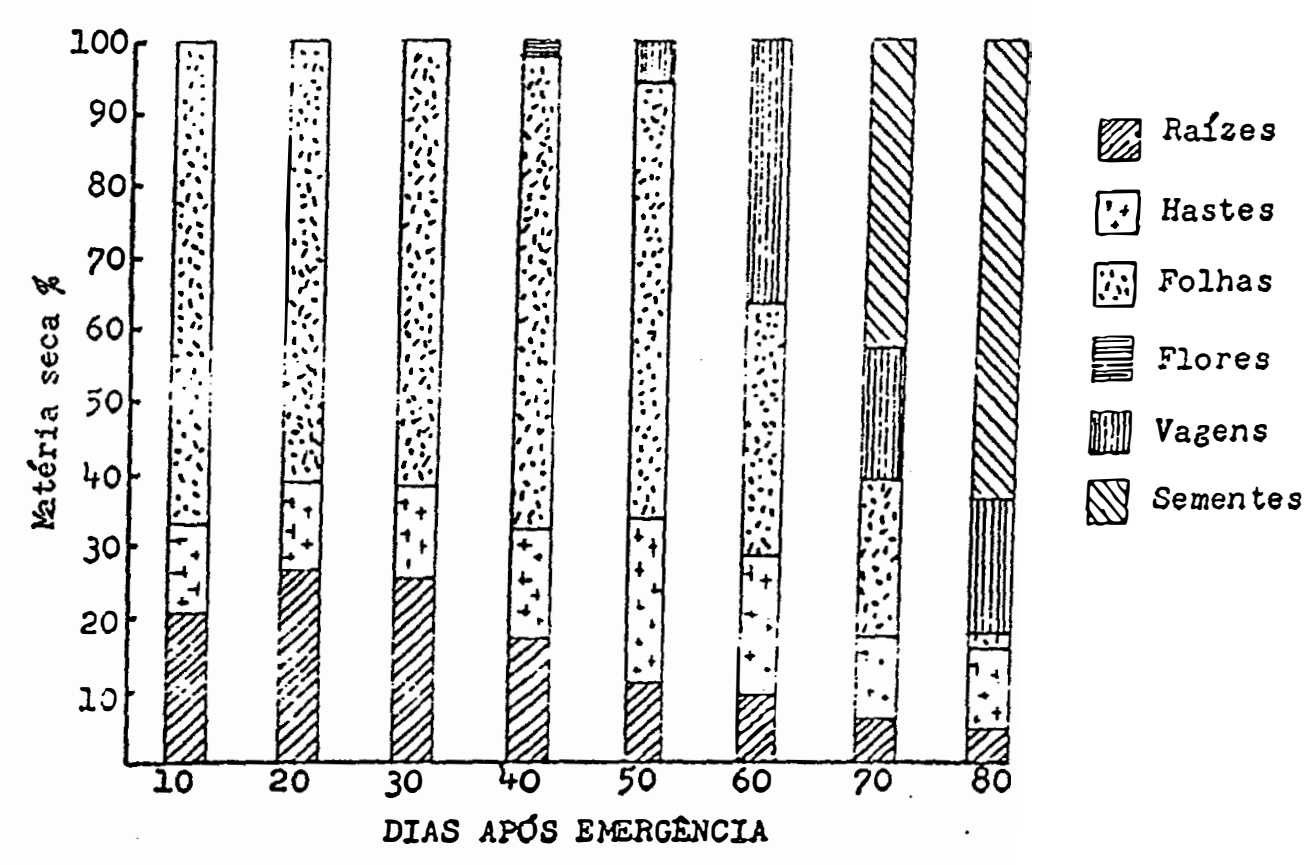

FIGURA 21. Distribuição percentual da matéria seca nos diversos órgãos do feijoeiro cultivar Carioca. 


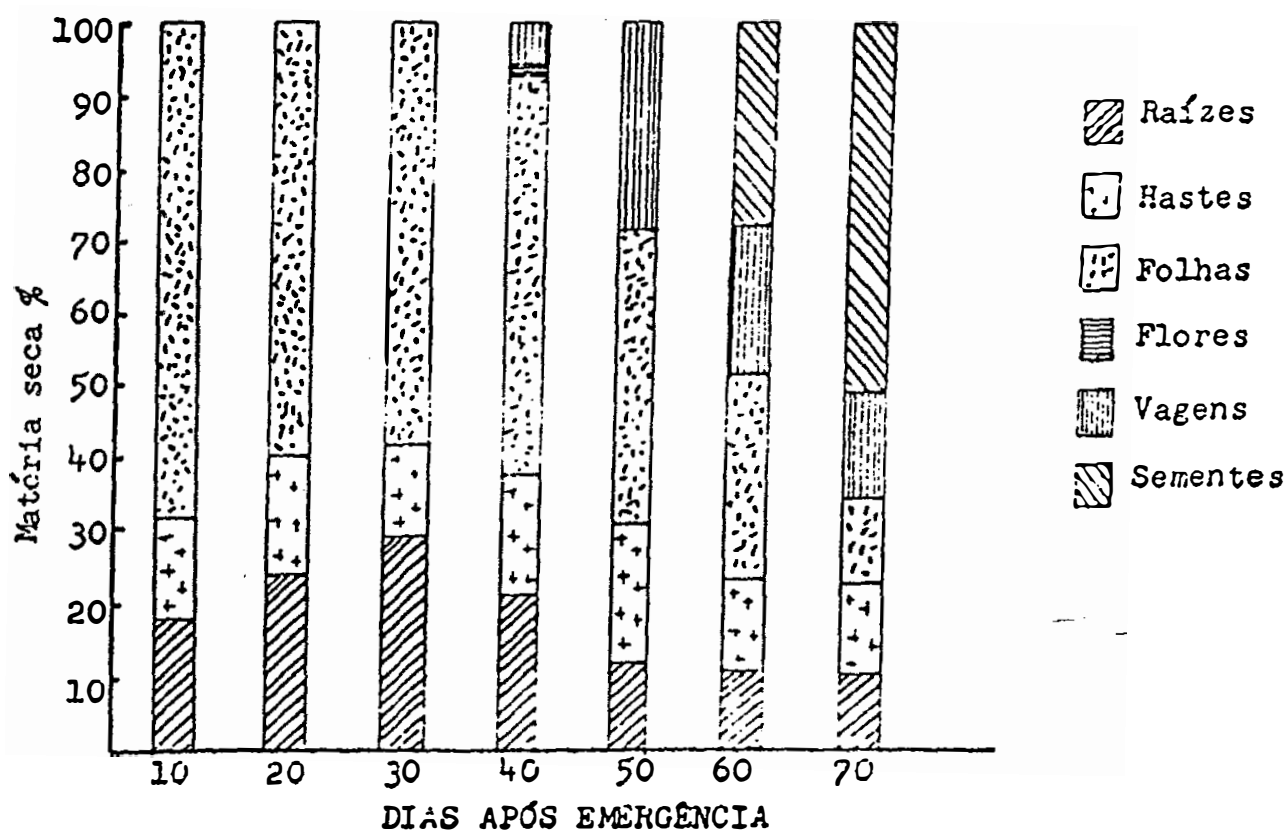

FIGURA 22. Distribuicão percentual da matéria seca nos diversos órgãos do feijoeiro cultivar Goiano Precoce. 


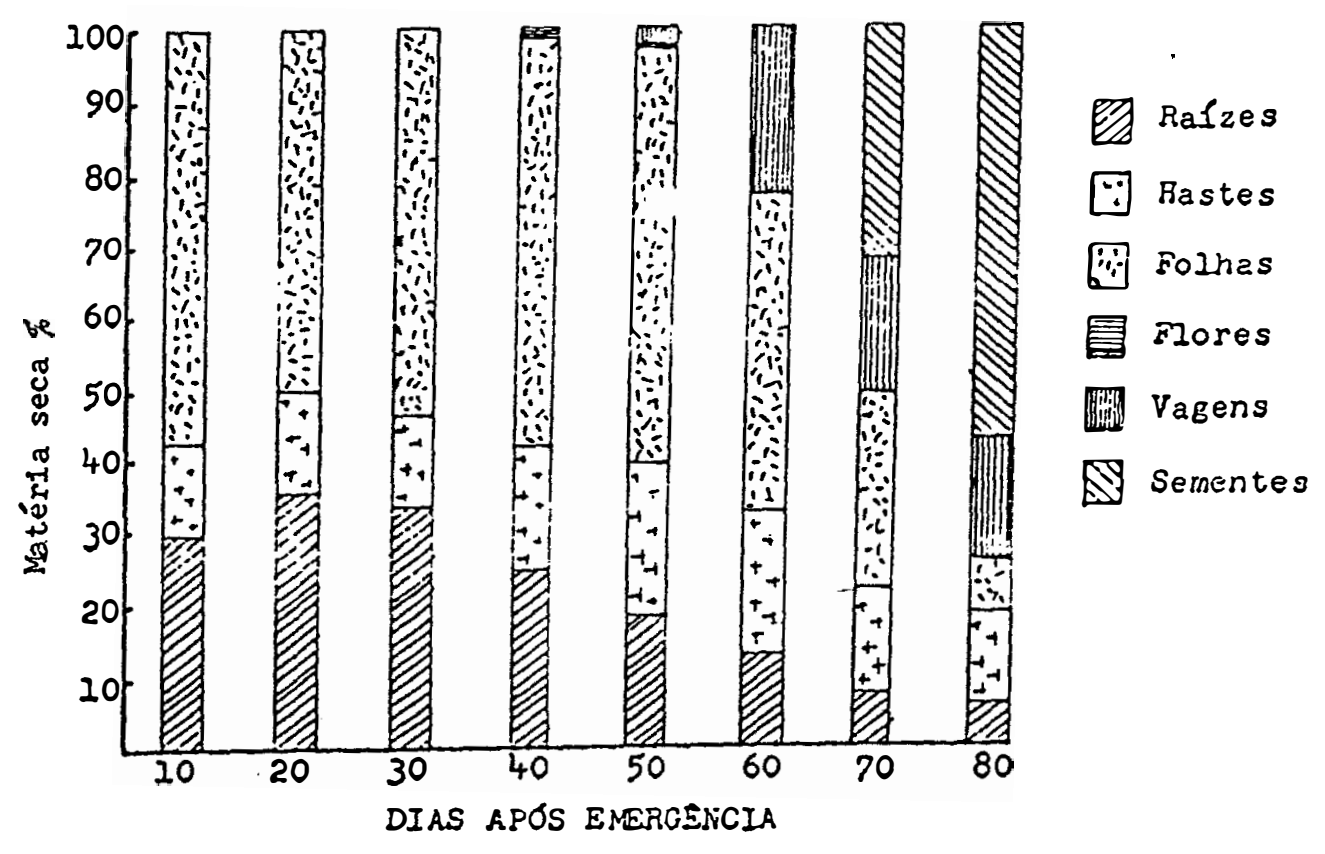

FIGURA 23. Distribuição percentual da matéria seca nos diversos órgãos do feijoeiro cultivar Rico 23. 


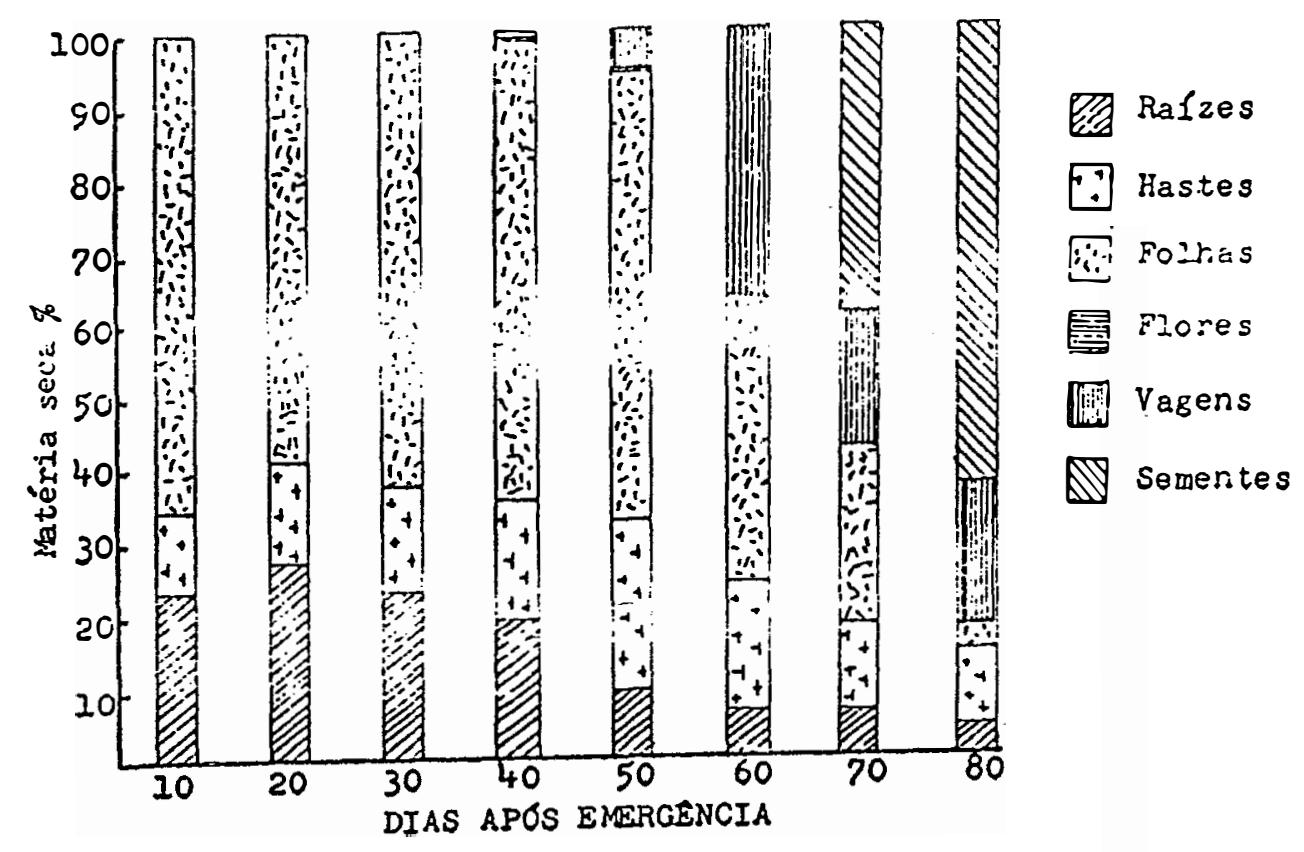

FIGURA 24. Distribuição percentual da matéria seca nos diversos órgãos do feijoeiro cultivar Rosinha G2 . 
diferença entre cultivares quanto a este caráter, que pode, dentro de determinados limites explicar diferenças no potencial produtivo de cultivares. Nestas considerações não se pode esquecer de fatores ambientais que interferem nesta medida, especialmente os relacionados à temperatura e umidade que podem promover uma aceleração na senescencia das folhas conforme söNDAHL et al. (1971), MACK e SINGH (1969), VIGLIERQUIO e WENT (1957) (altas temperaturas e seca), ou um retardamento e indução a crescimento de gemas vegetativas com baixas temperaturas e elevada umidade, BIENKLEY (1932) e SMITH e PRYOR (1962). Fatores de fertilidade do solo também podem estar associados a uma maior retenção foliar e elongação do ciclo vegetativo das plantas, tais como o excesso de nitrogênio ou a deficiência de zinco, conforme apontado por MELTON et al. (1970), AMBLER e BROWN (1969) e SCHELLEMBERGER e ADAMS (1971) .

\subsection{Absorção de nutrientes}

Nos quadros 5 a 9 são apresentados os teores de nutrientes determinados nas raízes dos cinco cultivares de feijoeiro; nas diversas idades das plantas, e nas figuras 25 a 29 é apresentado o acúmulo dos mesmos neste órgão.

Quanto ao nitrogênio, quadro 5 e figura 25, observou-se variação em seu teor entre cultivares e entre as épocas de amostragem. De maneira geral os maiores teores são encontrados 
nas fases iniciais do desenvolvimento das plantas, fato lógico se considerarmos que nas fases iniciais as raízes são drenos preferenciais no desenvolvimento das plantas, conforme citado por LOPES (1988). Os cultivares Rico 23, Rosinha G-2 e Goiano Precoce foram os que apresentaram maiores valores nas fases iniciais. As maiores quantidades acumuladas, em função da matéria seca produzida, foram observadas ao redor do $50^{\circ}$ dia após a emergência. No final do ciclo, Bico de Ouro e Rosinha G2 apresentaram os menores valores e Goiano Precoce e Rico 23 os maiores, conforme pode ser observado na figura 25 .

o fósforo nas raízes, quadro 6 e figura 26, apresenta relações variáveis em seu teor com a idade das plantas, no entanto, entre cultivares tanto no início como no final do ciclo, os teores são semelhantes. As maiores quantidades de fósforo nas raízes. são observadas aos 50 dias após a emergência para os cultivares Bico de Ouro, Goiano Precoce e Rosinha G2, aos $50 / 60$ dias para Rico 23 e 60/70 dias para Carioca. 
QUADRO 5. Teor em percentagem de nitrogênio nas raízes do feijoeiro nas diversas idades da planta.

\begin{tabular}{|c|c|c|c|c|c|c|c|c|c|}
\hline \multirow{2}{*}{ CULTIVARRS } & \multicolumn{5}{|c|}{ DIAS APOS } & \multicolumn{4}{|c|}{ BHERGEHCIA } \\
\hline & 10 & 20 & 30 & 40 & & 50 & 60 & 70 & 80 \\
\hline Bico de ouro & 2,42 & 2,88 & 2,23 & 2,08 & & 2,46 & 1,80 & 2,11 & 1,55 \\
\hline Carioca & 3,18 & 3,40 & 2,64 & 2,41 & & 2,46 & 2,07 & 2,17 & 1,56 \\
\hline Goieno Precoce & 3,96 & 3,33 & 2,46 & 2,33 & & 2,45 & 2,08 & 1,94 & -- \\
\hline Rico 23 & 4,36 & 3,50 & 2,24 & 2,24 & & 2,40 & 2,29 & 1,92 & 1,65 \\
\hline Rosinha G-2 & 4,07 & 3,24 & 2,36 & 2,26 & & 2,60 & 2,48 & 1,95 & 1,65 \\
\hline
\end{tabular}

QUADRO 6. Teor em percentagem de fósforo nas raízes do feijoeiro nas diversas idades das plantas.

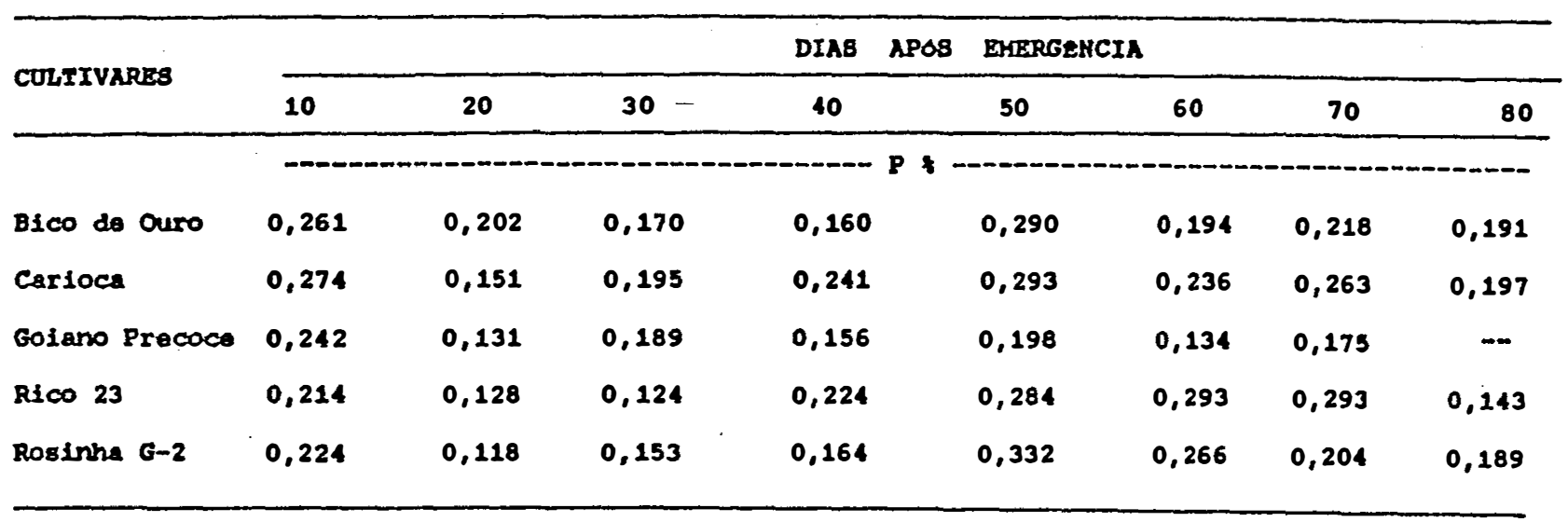




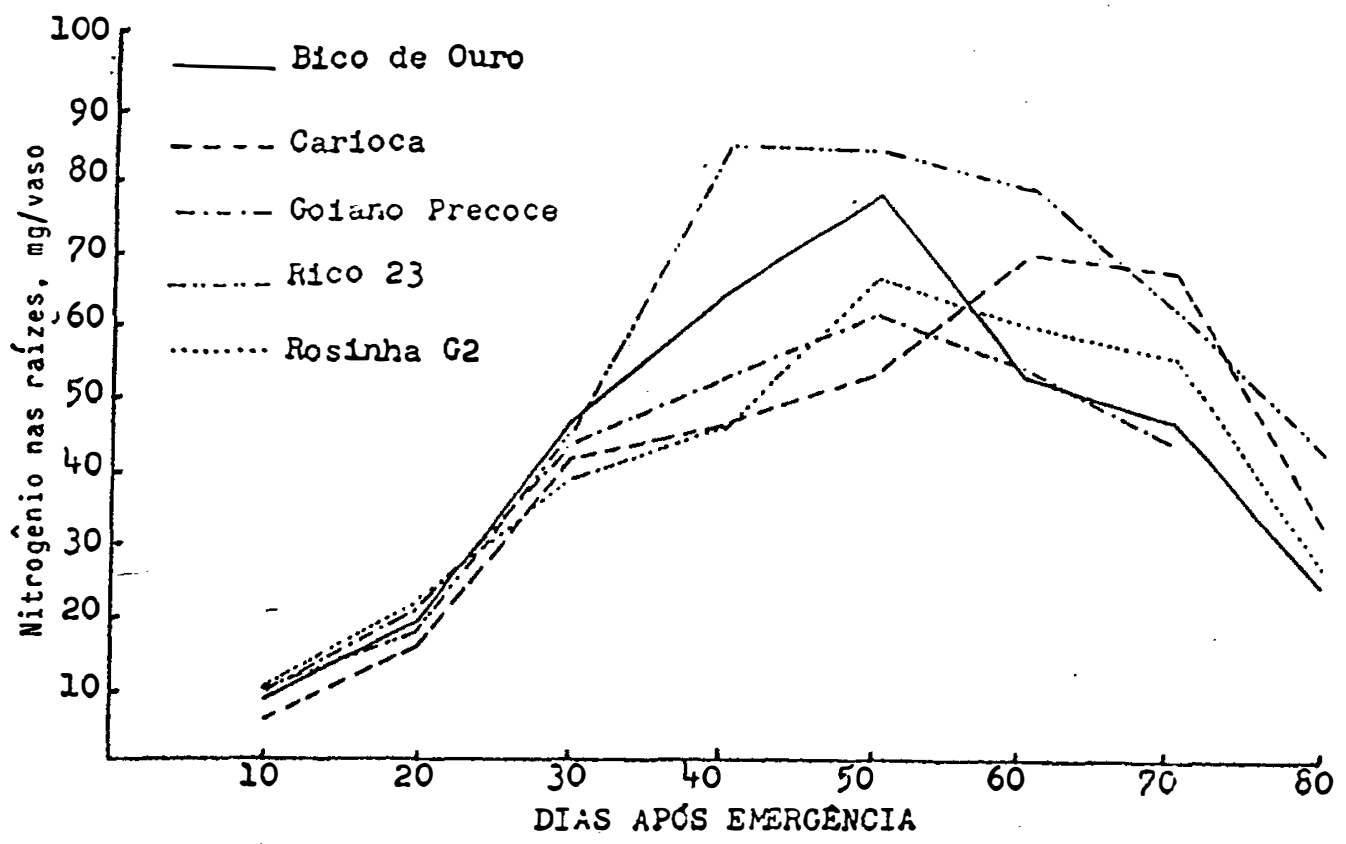

FIGURA 25. Acúmulo de nitrogênio nas raízes do feijoeiro em $\mathrm{mg} / \mathrm{vaso}$ contendo cada um duas plantas. 


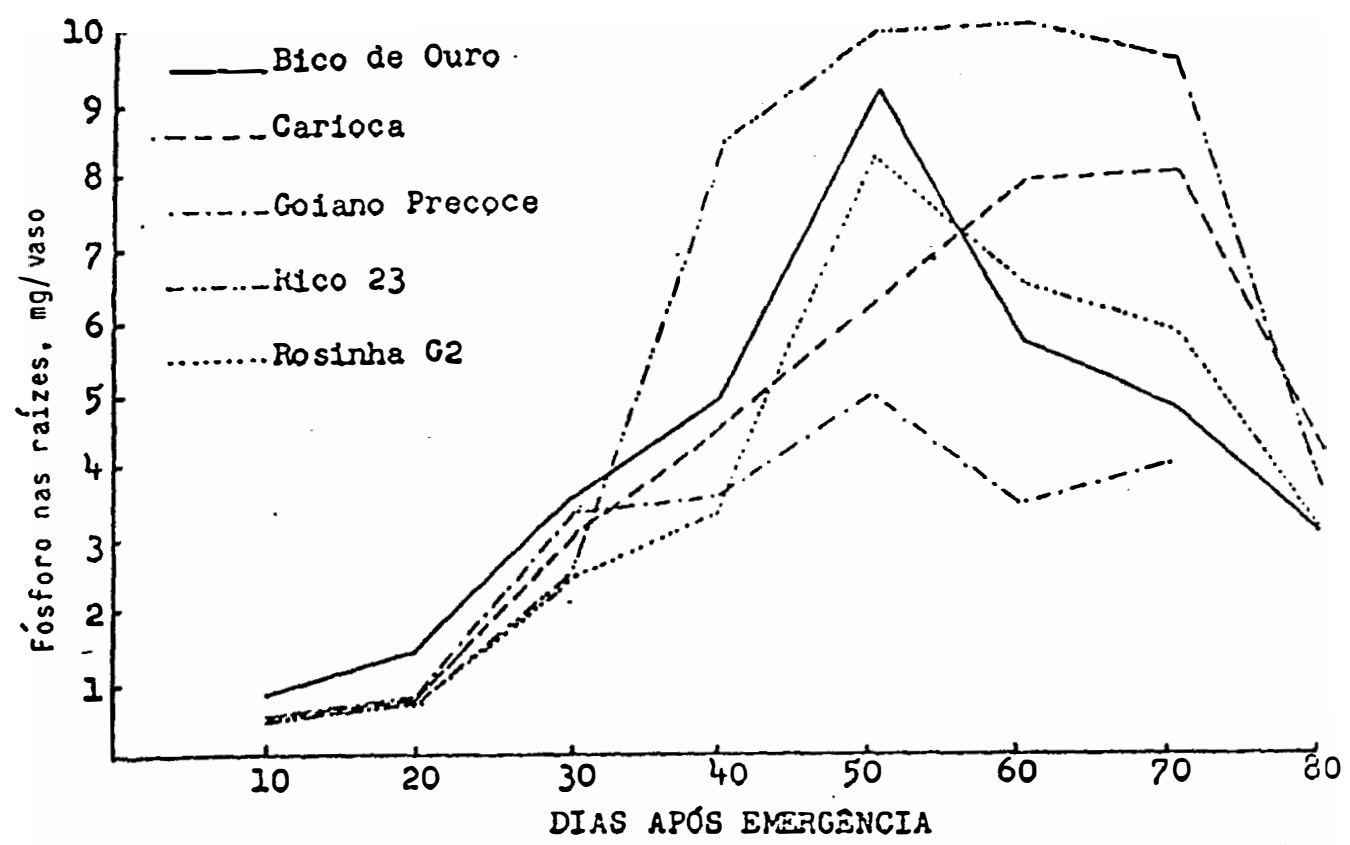

FIGURA 26. Acúmulo de fósforo nas raízes do feijoeiro em mg/vaso contendo cada um duas plantas. 
De maneira geral, para todos os cultivares os maiores teores de potássio nas raízes são observados aos 10 e 30 dias após a germinação, havendo uma tendência de diminuição nas fases finais do ciclo das plantas, conforme quadro 7 . Nota-se grande disparidade entre a quantidade absorvida e época de maior acúmulo entre cultivares, figura 27, sendo o cultivar Rico 23 o que maiores quantidades absorveu. Ao final do ciclo das plantas, há perda de potássio pelas raízes, causada pela senescência do sistema radicular, o que explica as reduções observadas para todos os demais nutrientes uma vez que o acúmulo é função maior da matéria seca presente.

Os valores para cálcio, quadro 8, são aproximadamente constantes quanto ao teor, apresentando menores valores nas fases iniciais os cultivares Bico de Ouro e Carioca. As menores quantidades absorvidas são observadas para o cultivar Rosinha G2 e as maiores para Rico 23. Dependendo do cultivar as maiores quantidades são encontradas entre os 40 e 70 dias de idade das plantas, conforme é apresentado na figura 28.

Os teores e as quantidades de magnésio nas raízes. nas diversas idades das plantas são apresentados no quadro 9 e figura 29. É de se notar a constância e pequena variação nos teores, sendo observadas as maiores quantidades absorvidas a partir 
QUADRO 7. Teor de potássio em percentagem, nas raízes do feijoeiro nas diversas idades das plantas

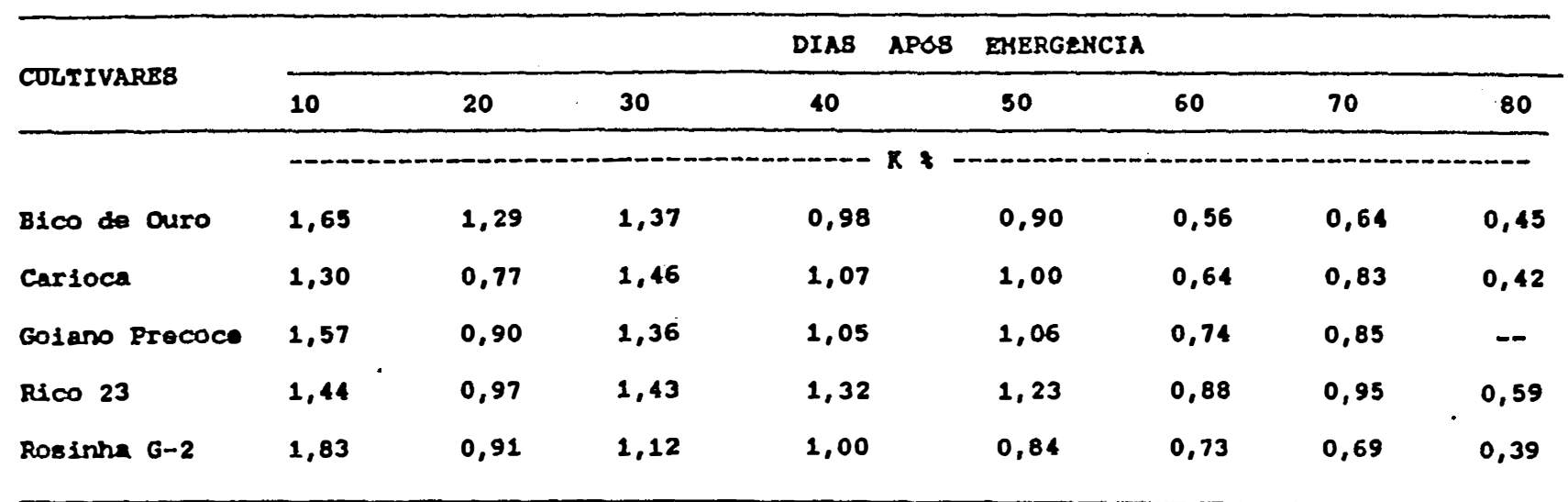

QUADRO 8. Teor de cálcio em percentagem, nas raízes do feijoeiro nas diversas idades das plantas.

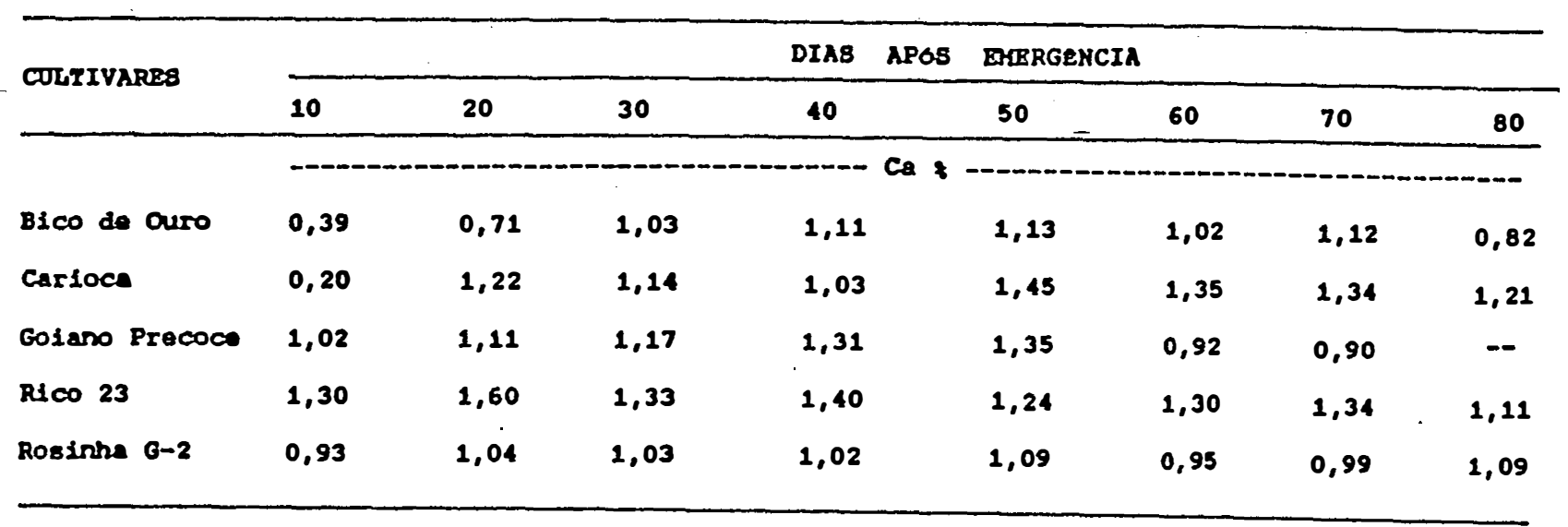




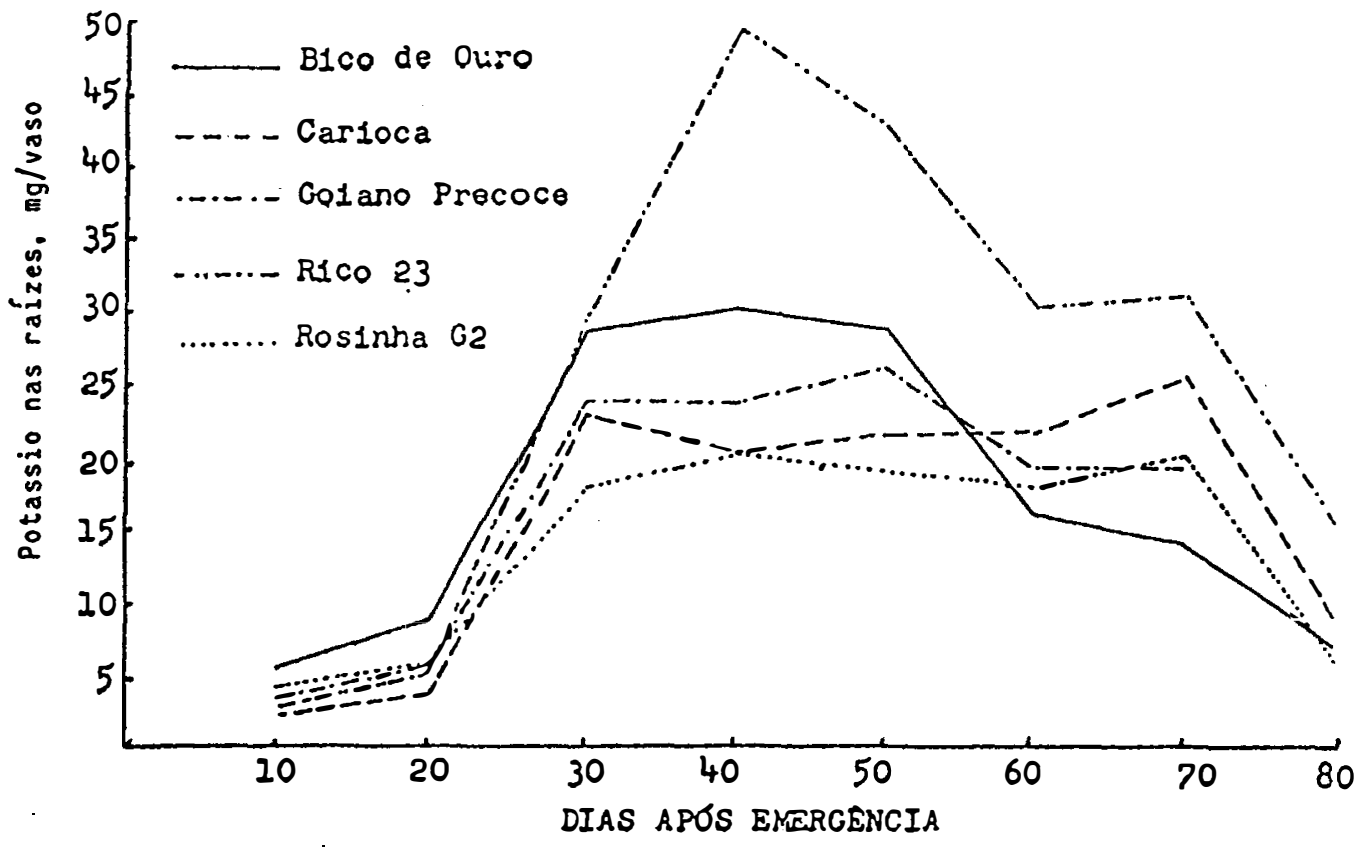

FIGURA 27. Acúmulo de potássio nas raízes do feijoeiro em $\mathrm{mg} / \mathrm{vaso}$ contendo cada um dua plantas. 


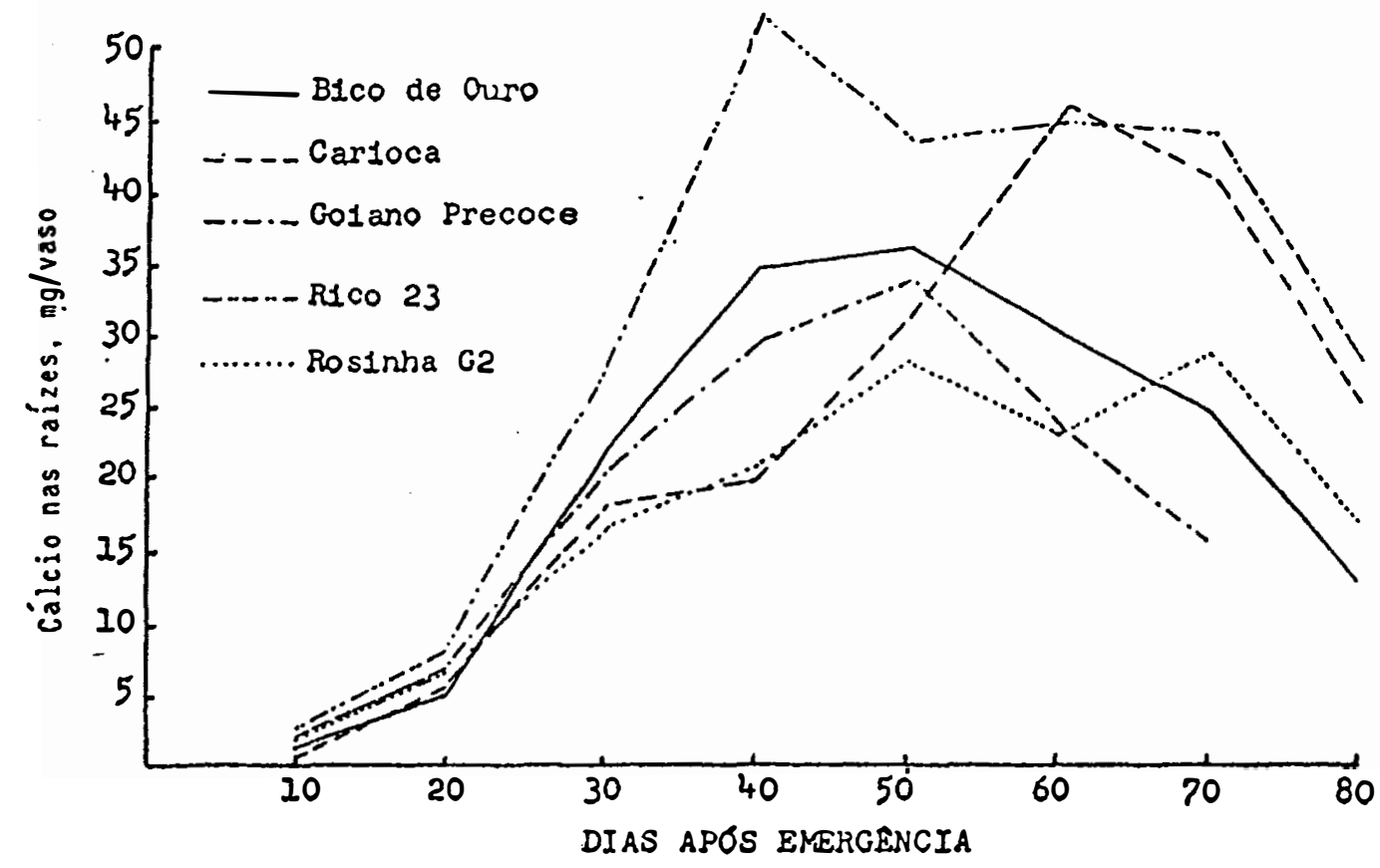

FIGURA 28. Acúmulo de cálcio nas raízes do feijoeiro em mg/vaso contendo cada um dua plantas. 
QUADRO 9. Teor de magnésio em percentagem, nas raízes do feijoeiro nas diversas idades das plantas.

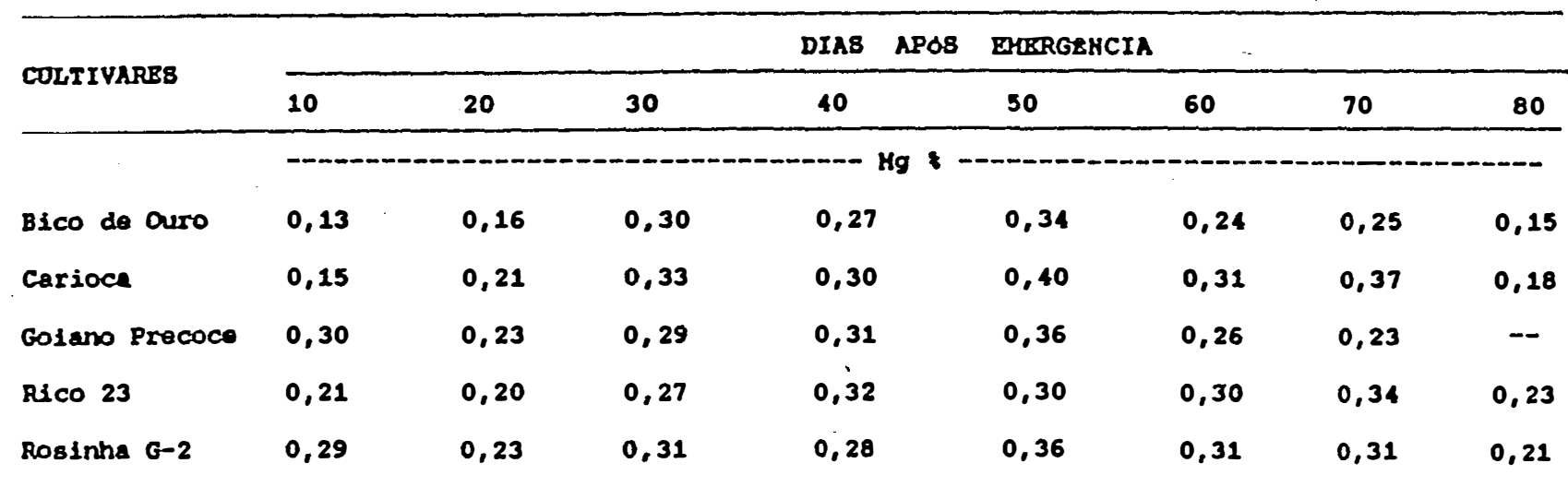

QUADRO 10. Teor em percentagem de nitrogênio nas hastes do feijoeiro nas diversas idades das plantas.

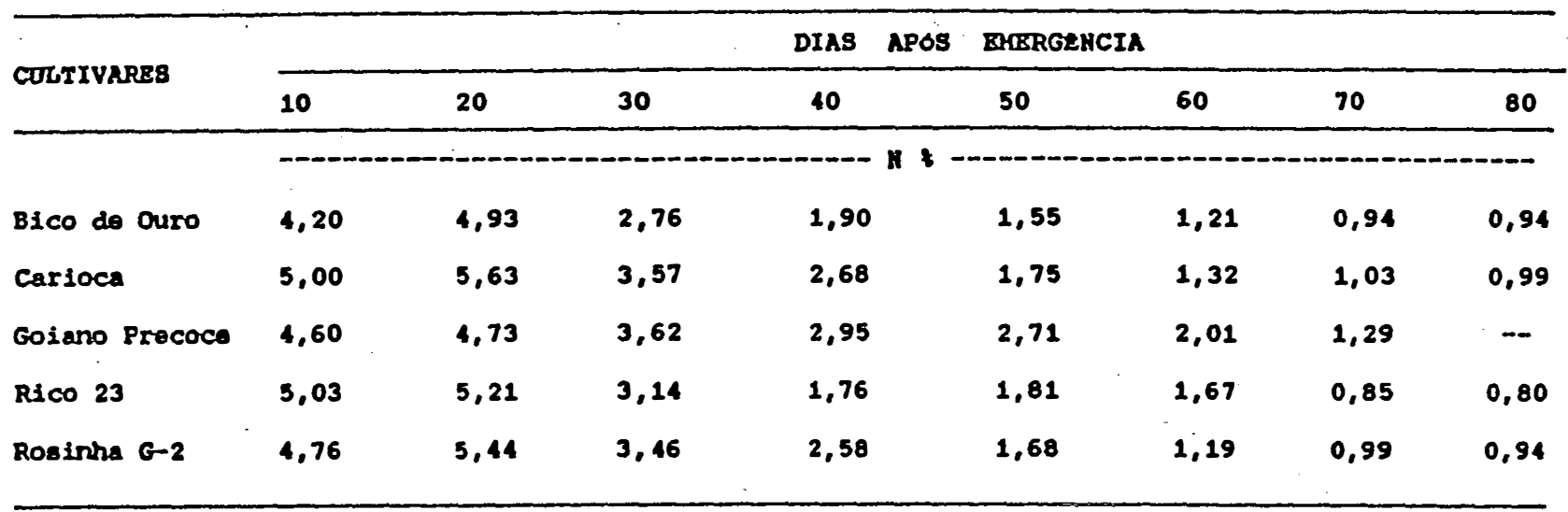




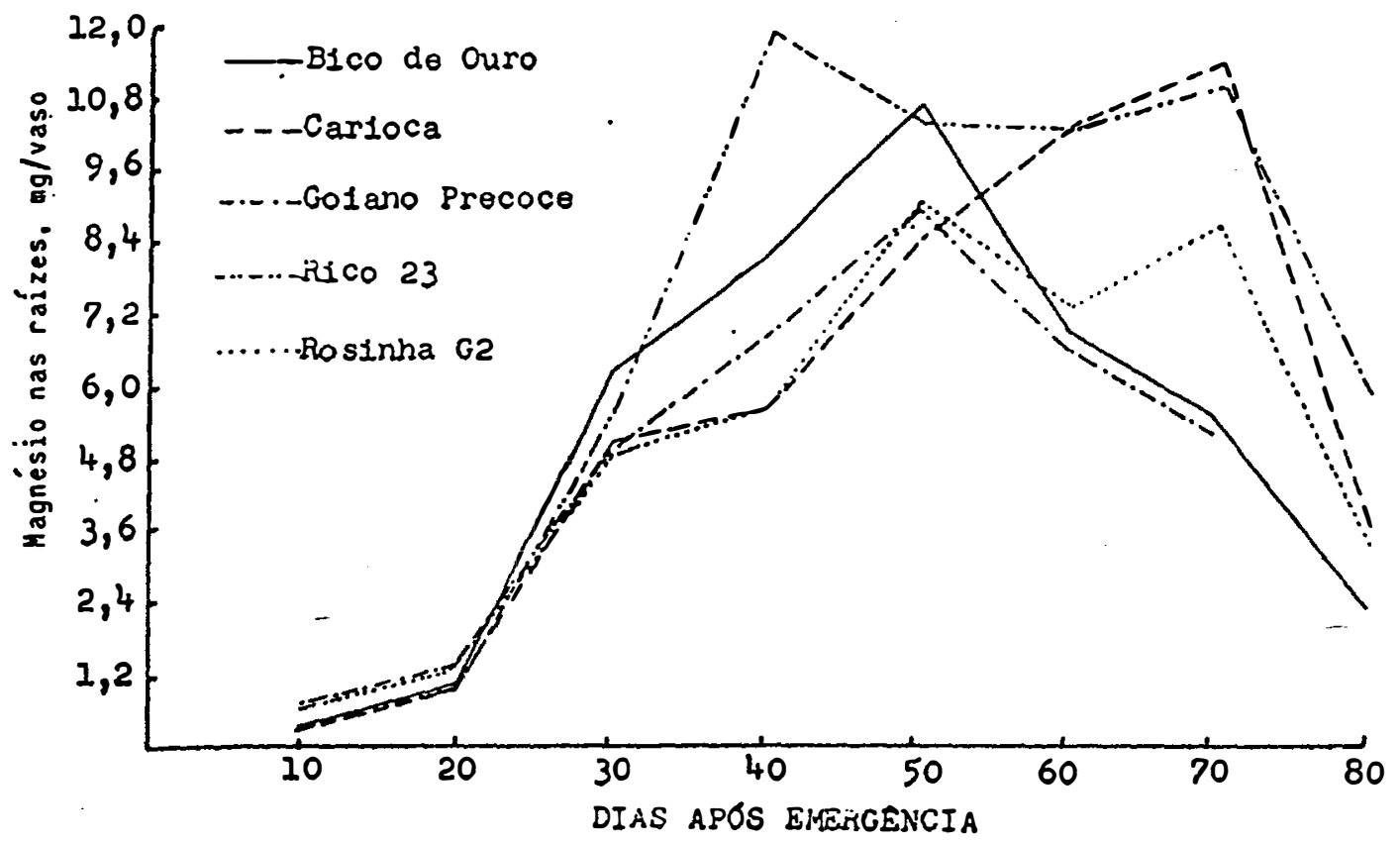

FIGURA 29. Acúmulo de magnésio nas raízes do feijoeiro em mg/vaso contendo cada um duas plantas. 
do $40^{\circ}$ dia após a emergência para o cultivar Rico 23 e a partir do $50^{\circ}$ para os demais.

Os valores para teores e quantidades de nutrientes determinados nas hastes dos cinco cultivares de feijoeiro nas diversas idades das plantas encontram-se nos quadros 10 a 14 e figuras 30 a 34 .

Há uma clara curva decrescente para os teores de nitrogênio nas hastes, mostrando que este elemento não se fixa nestes órgãos. Quanto à quantidade absorvida observa-se valores máximos ao redor do $50^{\circ}$ dia após a emergência, havendo posteriormente uma queda até o final do ciclo. Estes dados são apresentados no quadro 10 e figura 30, notando-se ainda grande semelhança de tendência para os cinco cultivares, e são semelhantes às tendências mostradas por MAFRA (1972) e COBRA NETTO (1967) .

No quadro 11 são apresentados os valores para fósforo determinado nas hastes do feijoeiro, observando-se alguma variação nas fases iniciais, mas uma clara redução nas fases finais quanto ao teor de fósforo nas hastes. Para todos os cultivares as maiores quantidades acumuladas estão ao redor de $50^{\circ}$ e $60^{\circ}$ dia após a emergência, conforme figura 31, acompanhando por certo o acúmulo de matéria seca.

Os teores e as quantidades de potássio nas hastes do feijoeiro são apresentados no quadro 12 e figura 32 . Os 


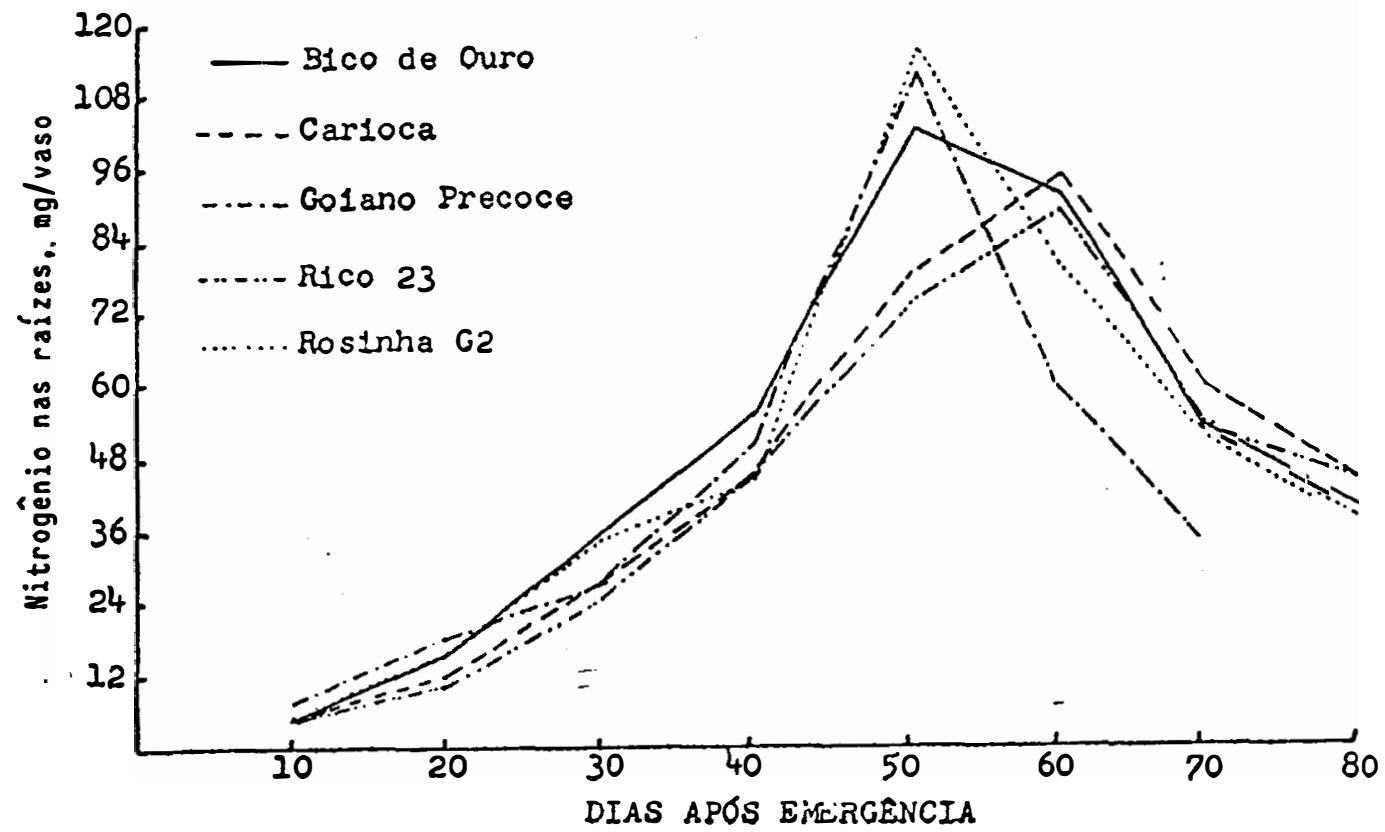

FIGURA 30. Acúmulo de nitrogênio nas hastes do feijoeiro em mg/vaso contendo cada um duas plantas. 
QUADRO 11. Teor de fósforo em percentagem nas hastes do feijoeiro nas diversas idades das plantas.

\begin{tabular}{|c|c|c|c|c|c|c|c|c|c|}
\hline \multirow{2}{*}{ CULTIVARES } & \multicolumn{5}{|c|}{ DIAS APOS } & \multicolumn{4}{|c|}{ EHERGEKCIA } \\
\hline & 10 & 20 & 30 & 40 & & 50 & 60 & 70 & 80 \\
\hline Bico do Ouro & 0,180 & 0,137 & 0,240 & 0,151 & & 0,157 & 0,122 & 0,089 & 0,086 \\
\hline Carioca & 0,212 & 0,145 & 0,266 & 0,211 & & 0,179 & 0,117 & 0,093 & 0,078 \\
\hline Goiano Precoce & 0,178 & 0,138 & 0,191 & 0,137 & & 0,140 & 0,110 & 0,092 & -- \\
\hline Rico 23 & 0,176 & 0,119 & 0,243 & 0,207 & & 0,220 & 0,191 & 0,098 & 0,067 \\
\hline Rosints G-2 & 0,222 & 0,153 & 0,269 & 0,211 & & 0,171 & 0,138 & 0,100 & 0,075 \\
\hline
\end{tabular}

QUADRO 12. Teor de potássio em percentagem nas hastes do feijoeiro nas diversas idades das plantas.

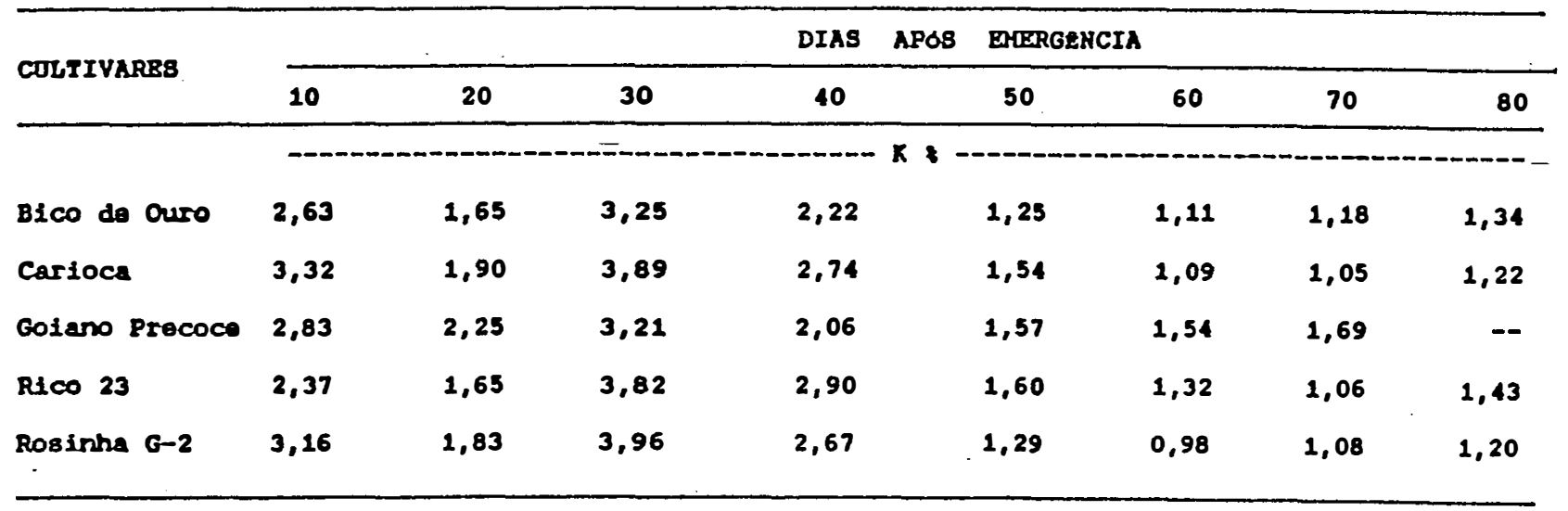




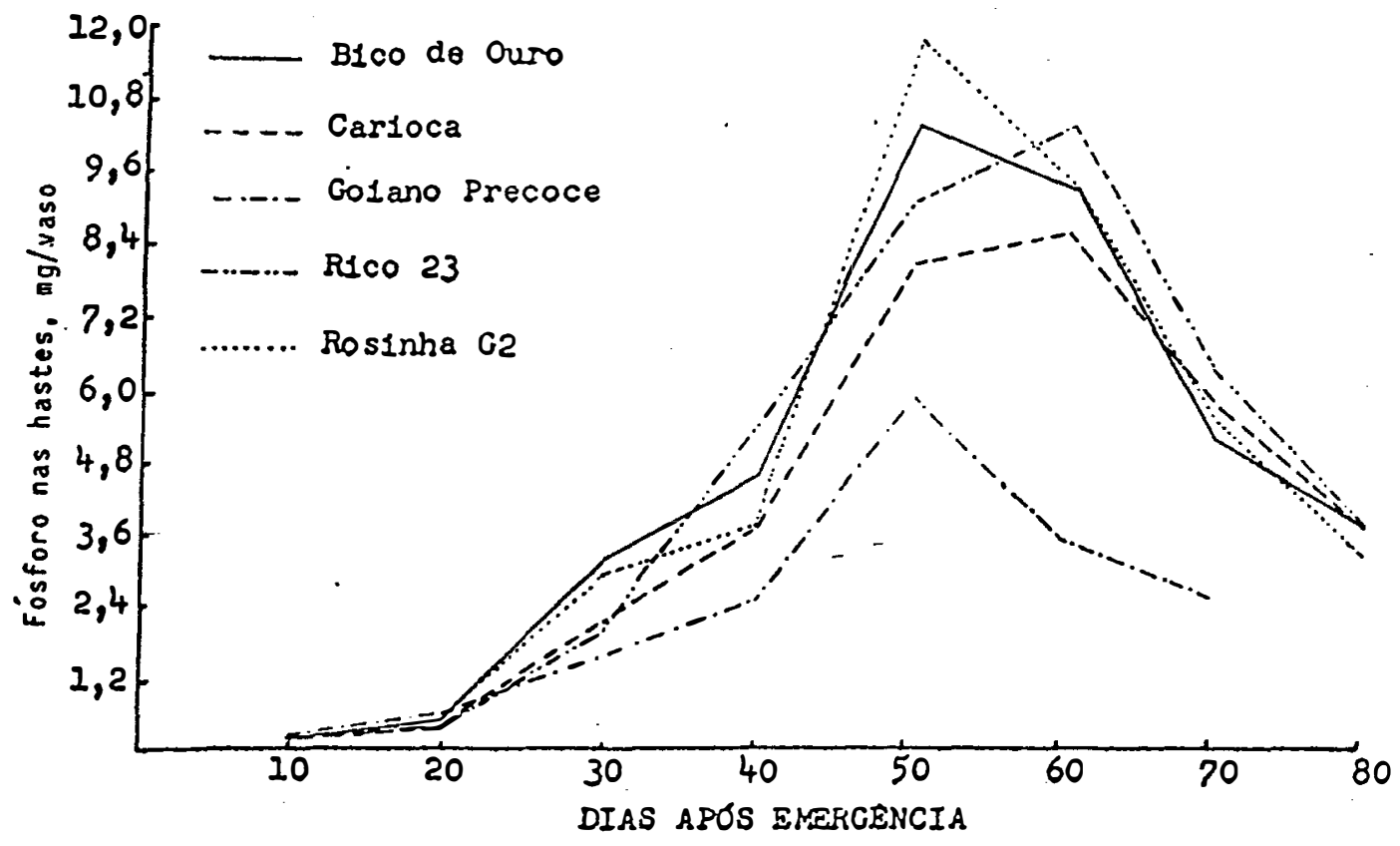

FIGURA 31. Acúmulo de fósforo nas hastes do feijoeiro em $\mathrm{mg} / \mathrm{vaso}$ contendo cada um duas plantas. 
valores mais elevados para teores são observados ao redor do $30^{\circ}$ após a emergência das plantas, daí até o final do ciclo há uma queda acentuada. Bico de Ouro e Carioca, apresentaram maior acúmulo de potássio nas hastes aos 60 dias, Goiano Precoce e Rosinha G2 aos 50 e Rico 23 ao final do ciclo. Exceto para este último cultivar que apresentou crescimento de matéria seca até o final do ciclo, os demais apresentaram decréscimo, porém não tão acentuado como para os nutrientes já apontados, indicando que parte ponderável do potássio acumulado pelas hastes nelas permanece até o final do ciclo, sendo pouco dele redistribuído.

Os teores mais elevados de cálcio nas hastes do feijoeiro são observados nas fases iniciais do ciclo, quadro 13, e de maneira geral há semelhança entre os valores apresentados pelos cultivares exceto para Goiano Precoce que mostrou teores mais baixos. No final do ciclo, para todos os cultivares houve um ligeiro acréscimo no teor de cálcio mostrando que o mesmo é pouco redistribuido, conforme citado por VIETS et al. (1954). Conforme se observa na figura 33, os cultivares Carioca, Rico 23 apresentaram maiores acúmulos no final do ciclo, e Bico de ouro, Goiano Precoce e Rosinha G2 nas fases intermediárias. Em relação ao total de cálcio absorvido pelas hastes, grande quantidade nelas permanece até o final do ciclo das plantas, como de fato seria de se esperar para nutriente que tem características de pouca mobilidade.

No quadro 14 e figura 34 são apresentados os valores para magnésio determinados nas hastes do feijoeiro. 


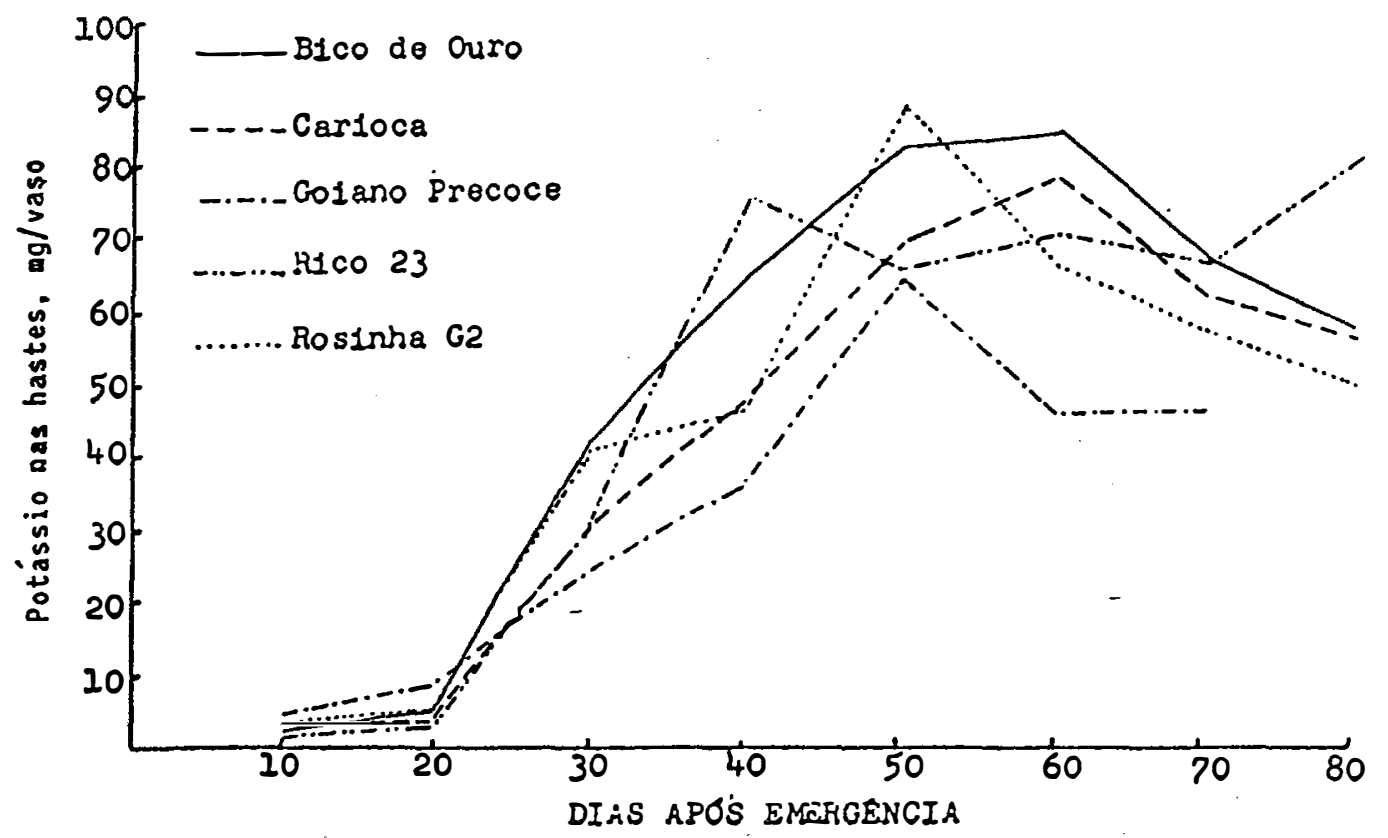

FIGURA 32. Acúmulo de potássio nas hastes do feijoeiro em $\mathrm{mg} / \mathrm{vaso}$ contendo cada um duas plantas. 


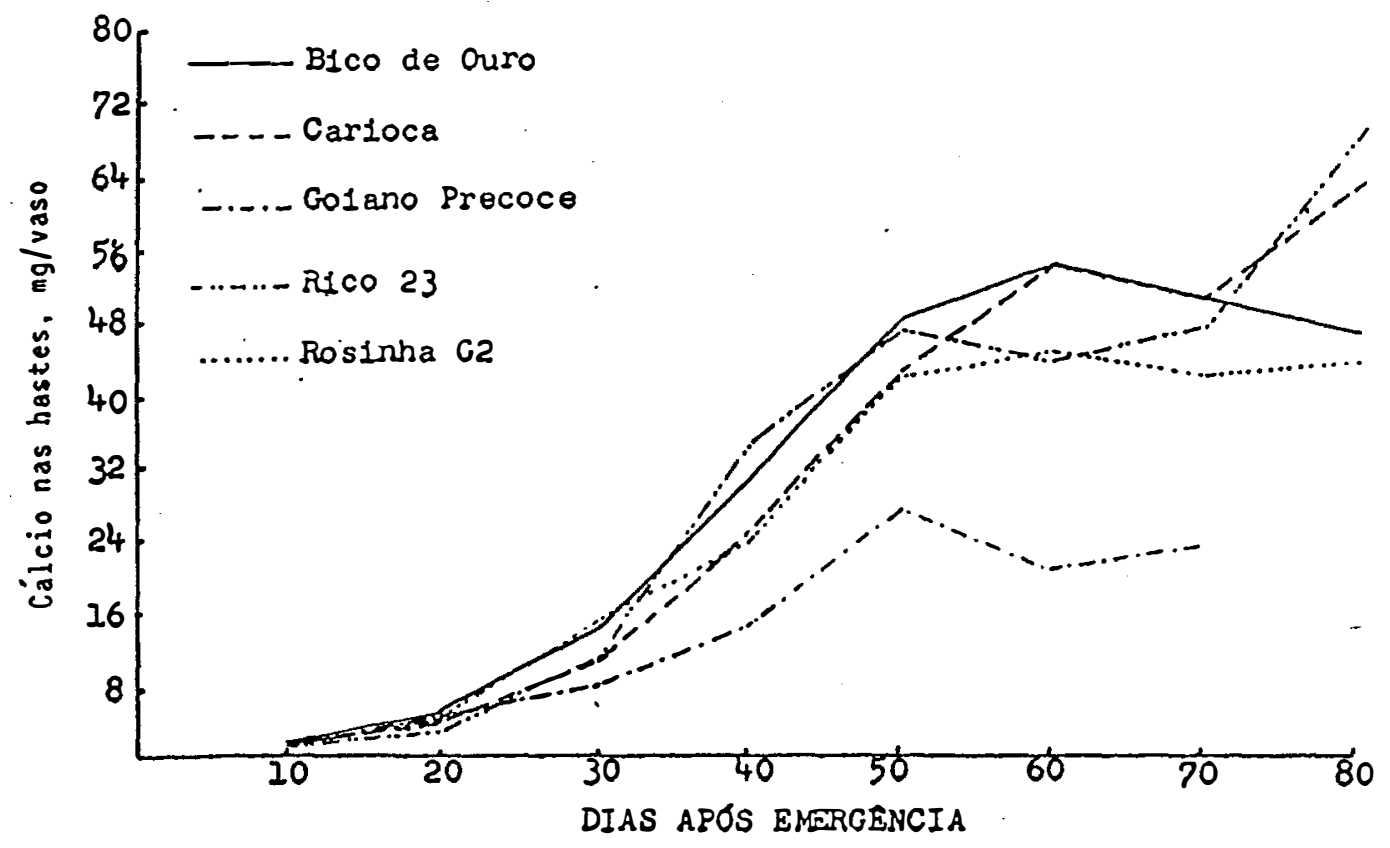

FIGURA 33. Acúmulo de cálcio nas hastes do feijoeiro em $\mathrm{mg} / \mathrm{vaso}$ contendo cada um duas plantas. 
QUADRO 13. Teor de cálcio em percentagem nas hastes do feijoeiro nas diversas idades das plantas.

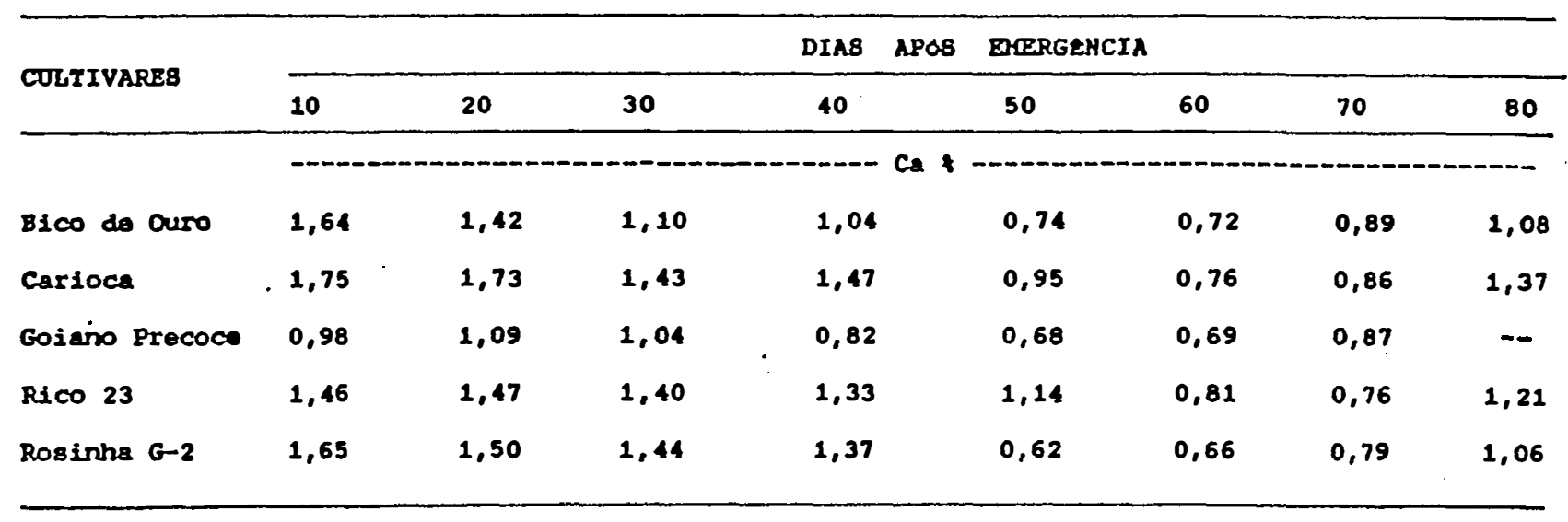

QUADRO 14. Teor de magnésio em percentagem nas hastes do feijoeiro nas diversas idades das plantas.

\begin{tabular}{|c|c|c|c|c|c|c|c|c|}
\hline \multirow{2}{*}{ CULTIVARBB } & \multicolumn{8}{|c|}{ DIAS APOB EMERGENCIA } \\
\hline & 10 & 20 & 30 & 40 & 50 & 60 & 70 & 80 \\
\hline Bico de ouro & 0,34 & 0,34 & 0,24 & 0,24 & 0,24 & 0,23 & 0,28 & 0,36 \\
\hline Carioce & 0,38 & 0,35 & 0,26 & 0,27 & 0,25 & 0,23 & 0,29 & 0,41 \\
\hline Goleno Precoce & 0,27 & 0,29 & 0.21 & 0,18 & 0,22 & 0,27 & 0,27 & -- \\
\hline Rico 23 & 0,44 & 0,40 & 0,28 & 0,31 & 0,31 & 0,28 & 0,34 & 0,44 \\
\hline Rosinisa 6-2 & 0,41 & 0,38 & 0,29 & 0,31 & 0,26 & 0,31 & 0,31 & 0,37 \\
\hline
\end{tabular}


Este nutriente apresentou tanto para teores quanto para quantidade absorvida a mesma tendência que o cálcio no mesmo órgão.

As folhas do feijoeiro apresentaram teores e acúmulos de nutrientes cujos valores encontram-se nos quadros 15 a 19 e figüras 35 a 39.

Os maiores teores. de nitrogênio nas folhas do feijoeiro são encontrados nas fases iniciais do ciclo das plantas, havendo uma queda posterior com o aumento da idade, quadro 15, esta redução no teor, com a maturidade, é devida primordialmente a translocação, CABALLERO et al. (1985), HAAG et al. (1967) e GALLO e MIYASAKA (1961).

Os valores de acúmulo mais elevados são observados ao redor do $50^{\circ}$ dia após a emergência em função da maior quantidade de matéria seca produzida, depois, devido à redução no teor e por certo devido à intensa translocação para as partes reprodutivas e à queda das folhas, reduz-se a quantidade de nitrogênio nestes órgãos, figura 35 .

Conforme quadro 16, os maiores teores de fósforo nas folhas são observados entré 30 e 50 dias após a emergência para os cinco cultivares. Há um acúmulo acentuado de fósforo até o $50^{\circ}$ dia após a emergência das plantas quando são observados os valores mais elevados, depois em função de menores teores e queda das folhas, há uma redução acentuada do fósforo contido nestes órgãos, cuja tendência é apontada na figura 36.

Para os cultivares Bico de Ouro, Carioca e Rosinha G2, os mais elevados teores de potássio nas folhas são observados 


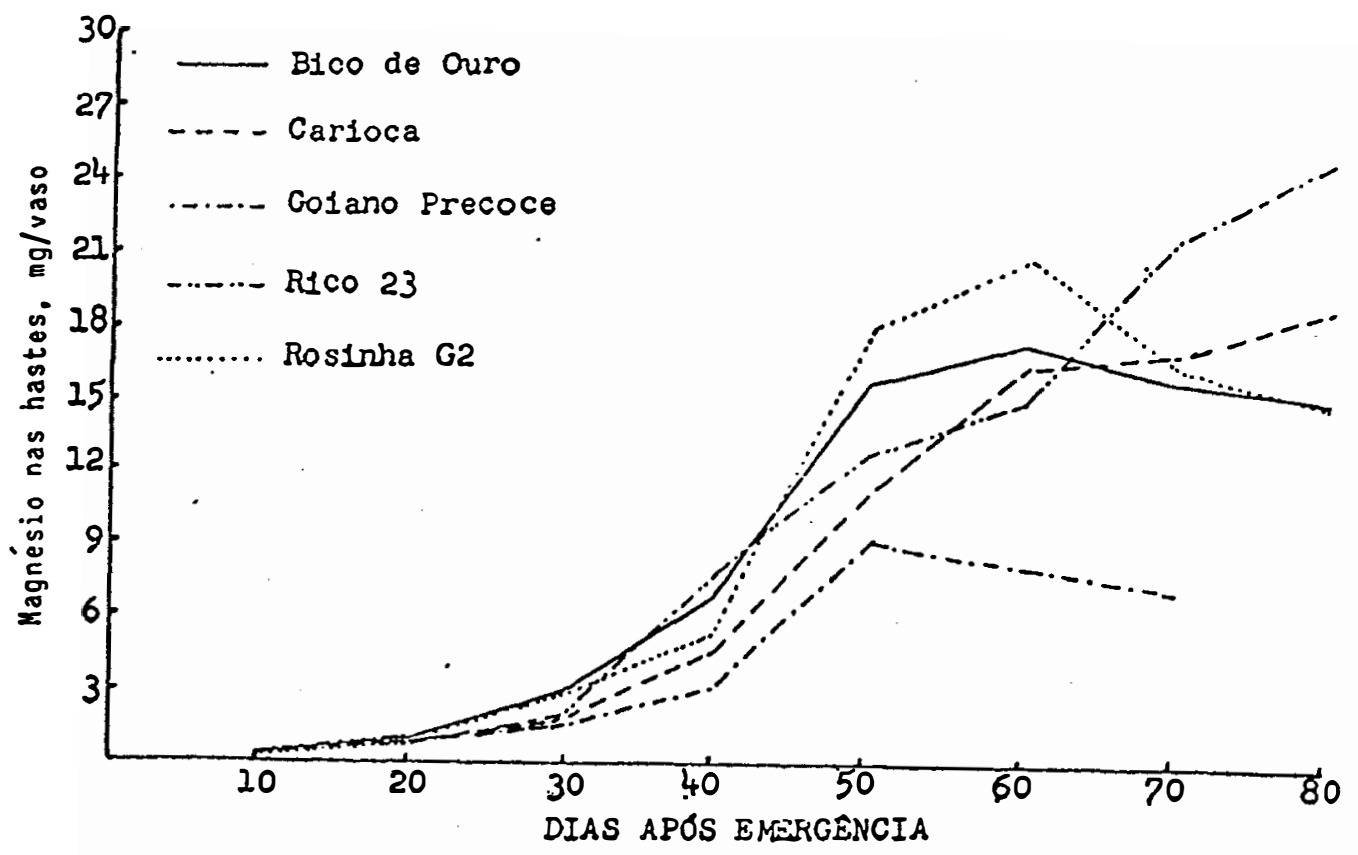

FIGURA 34. Acúmulo de magnésio nas hastes do feijoeiro em $\mathrm{mg} / v a s o$ contendo cada um duas plantas. 


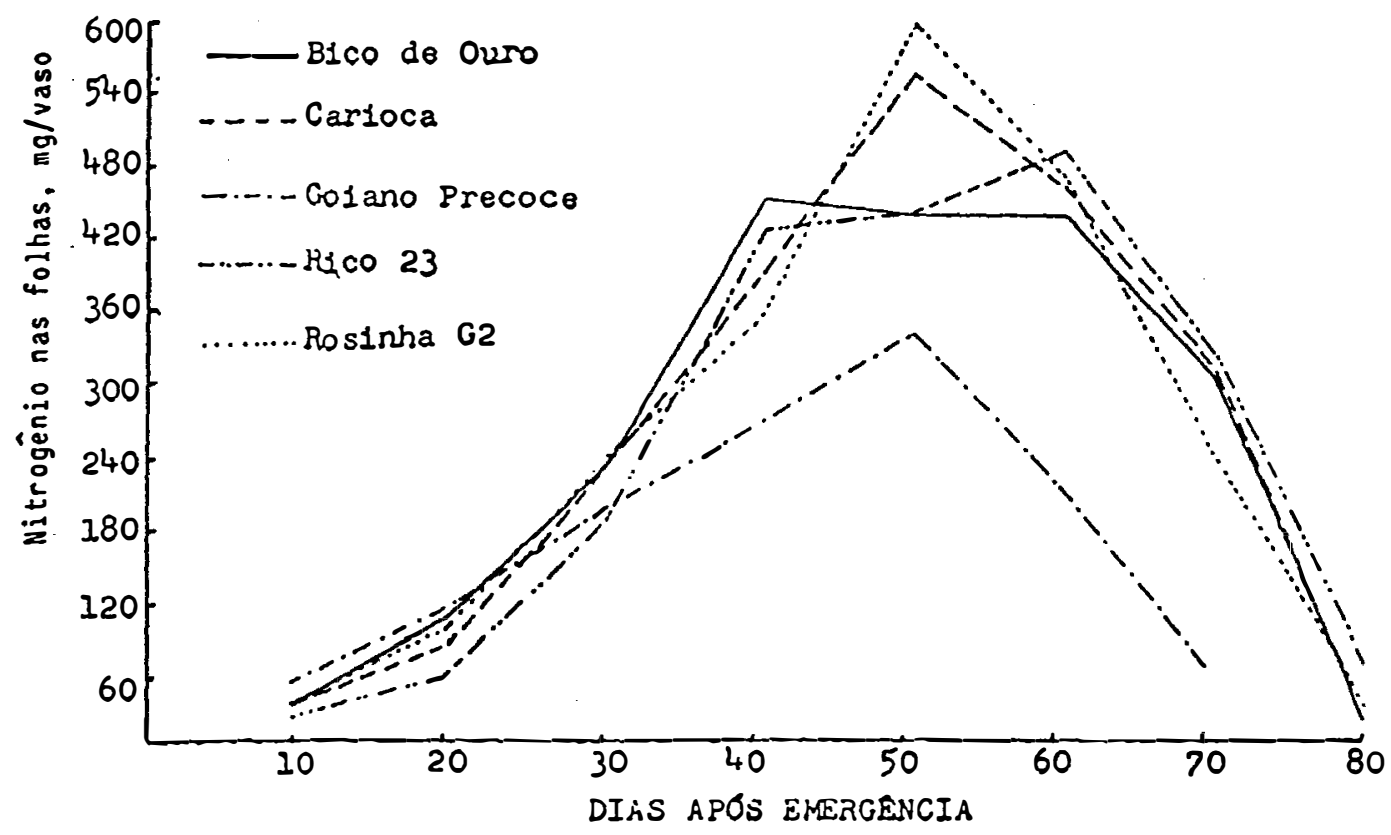

FIGURA 35. Acúmulo de nitrogênio nas folhas do feijoeiro em $\mathrm{mg} / \mathrm{vaso}$ contendo cada um duas plantas. 
QUADRO 15. Teor de nitrogênio em percentagem nas fol has do feijoeiro nas diversas idades da planta.

\begin{tabular}{|c|c|c|c|c|c|c|c|c|c|}
\hline \multirow{2}{*}{ COLTIVARRS } & \multicolumn{4}{|r|}{ DIAS } & APOS & \multicolumn{2}{|c|}{ ERERGENCIA } & \multirow[b]{2}{*}{70} & \multirow[b]{2}{*}{80} \\
\hline & 10 & 20 & 30 & 40 & & 50 & 60 & & \\
\hline & $\cdots$ & - & $-\cdots$ & $-\infty$ & H & $\cdots-$ & $\cdots$ & $\cdots$ & - \\
\hline Bico de ouro & 4,48 & 7,07 & 5,05 & 5,10 & & 3,40 & 3,60 & 2,72 & 2,19 \\
\hline Carioca & 3,35 & 7,14 & 5,73 & 5,22 & & 4,40 & 3,43 & 2,71 & 2,23 \\
\hline Goians Precoco & 5,56 & 6,66 & 5,56 & 4,62 & & 3,88 & 3,16 & 2,37 & -- \\
\hline Rico 23 & 5,38 & 7,46 & 5,48 & 4,76 & & 3,84 & 4,10 & 2,65 & 2,35 \\
\hline Rosinha $G-2$ & 4,95 & 6,81 & 5,32 & 5,14 & & 3,27 & 3,18 & 2,25 & 2,14 \\
\hline
\end{tabular}

QUADRO 16. Teor de fósforo em percentagem nas folhas do feijoeiro nas diversas idades das plantas.

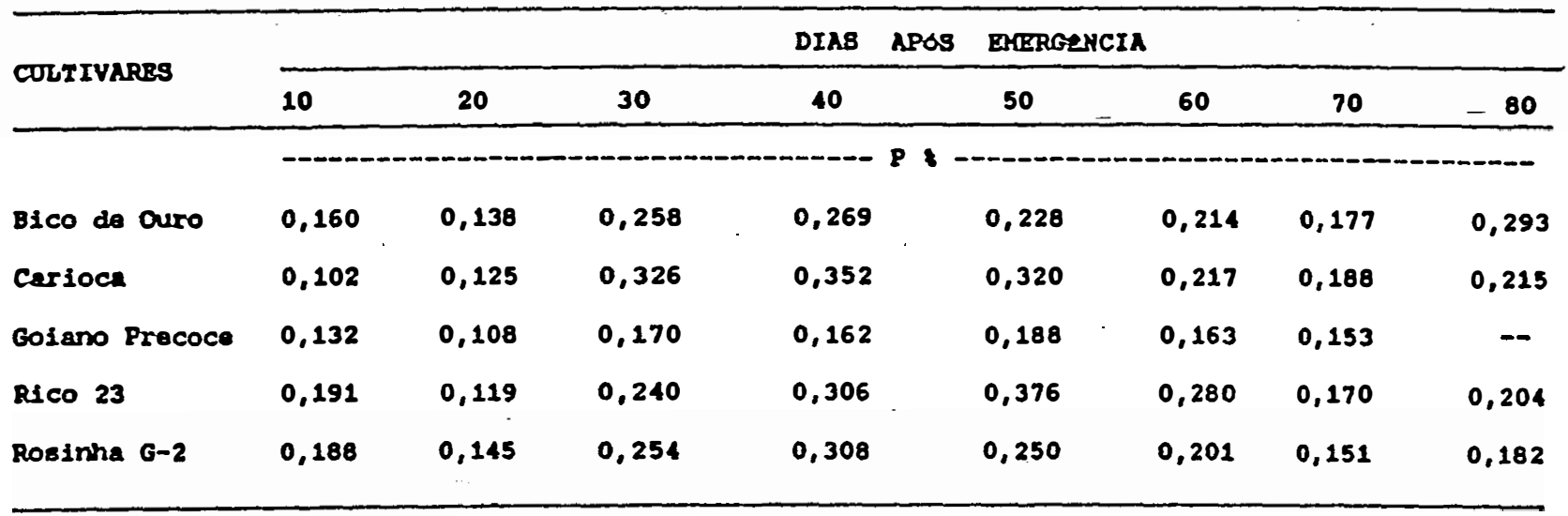




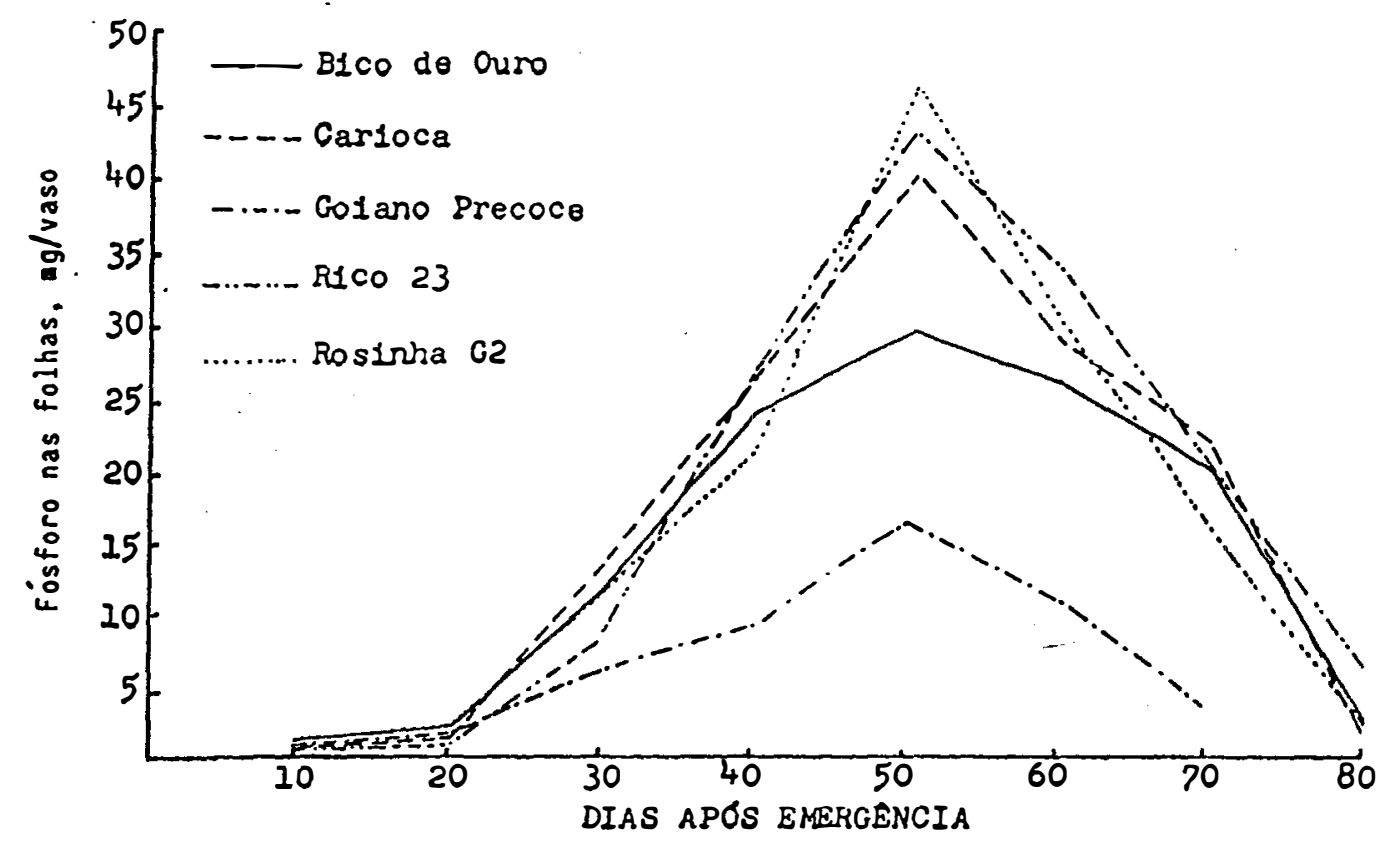

FIGURA 36. Acúmulo de fósforo nas folhas do feijoeiro em $\mathrm{mg} / \mathrm{vaso}$ contendo cada um duas plantas. 
40 dias após a emergência e para Goiano Precoce e Rico 23 aos 50. Todos os cultivares apresentaram maior acúmulo 50 dias após a emergência com Rosinha G2 mostrando quantidade mais elevada. Com a redução no teor e queda das folhas há diminuição acentuada na quantidade de potássio acumulada nas folhas do feijoeiro, conforme é apresentado na figura 37.

A evolução do teor de cálcio nas folhas do feijoeiro é mostrada no quadro 18, notando-se um crescimento constante com a idade das plantas fato bastante típico para nutriente de sabida baixa mobilidade, VIETS et al. (1954), GALLO e MIYASAKA (1961). As maiores quantidades são observadas nas fases finais do ciclo das plantas, havendo redução devido à queda das folhas. Todos os cultivares apresentaram esta tendência de maneira marcante conforme é mostrado na figura 38.

Com relação ao magnésio, observa-se pequena variação em seu teor nas folhas do feijoeiro em função da idade das plantas, quadro 19. Os maiores acúmulos deste nutriente são observados aos 50 dias após a emergência nos cultivares Goiano Precoce e Rosinha G2 e aos 60 dias para os demais. A queda das folhas influi sobremaneira na quantidade final de magnésio determinada. Os valores para este nutriente encontram-se na figura 39, e mostram tendência muito semelhante à do cálcio nesta parte da planta. 
QUADRO 17. Teor de potássio em percentagem nas foḷhas do feijoeiro nas diversas idades das plantas.

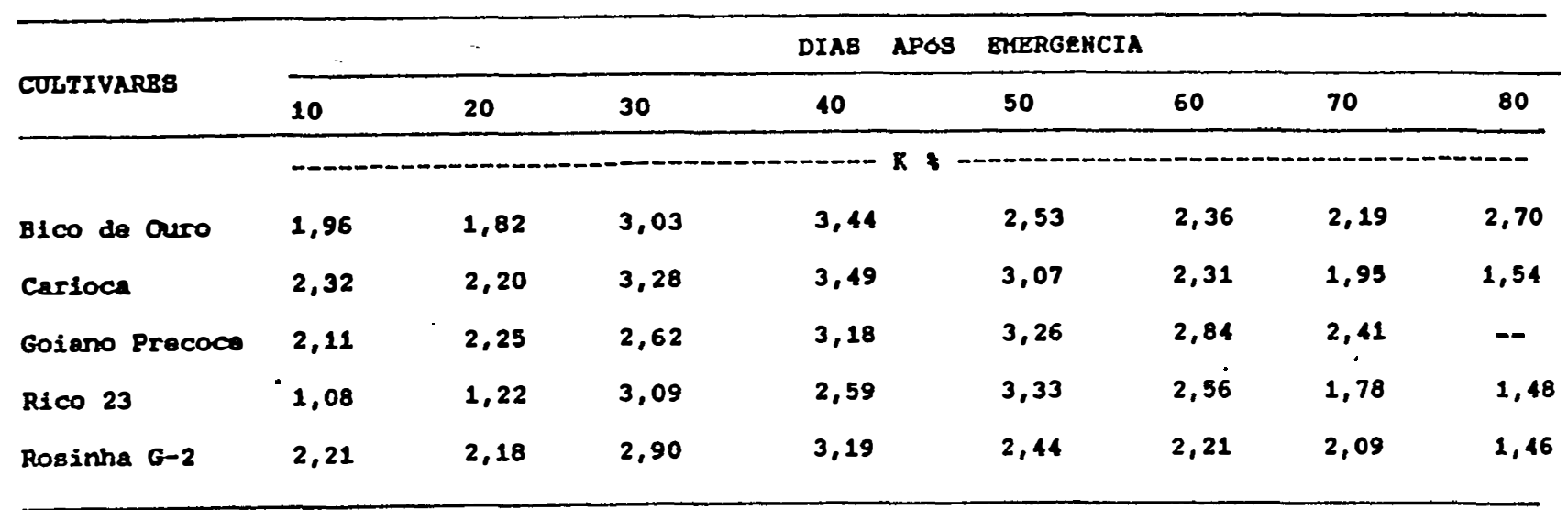

QUADRO 18. Teor de cálcio em percentagem nas folhas do feijoeiro nas diversas idades das plantas.

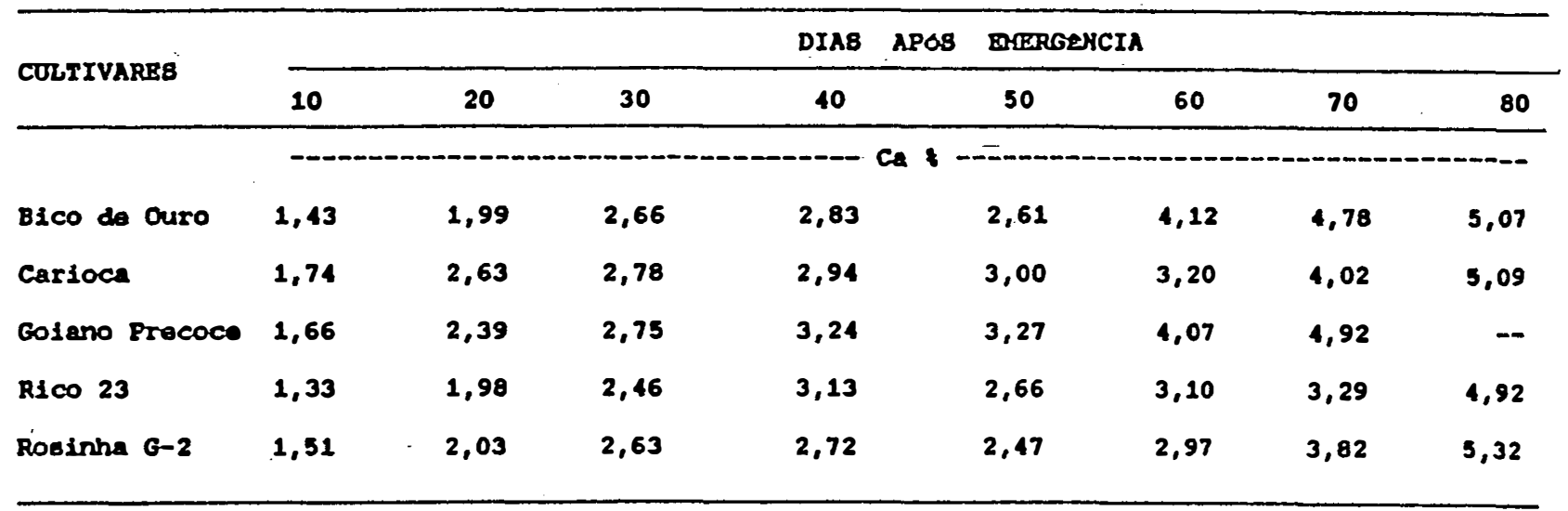




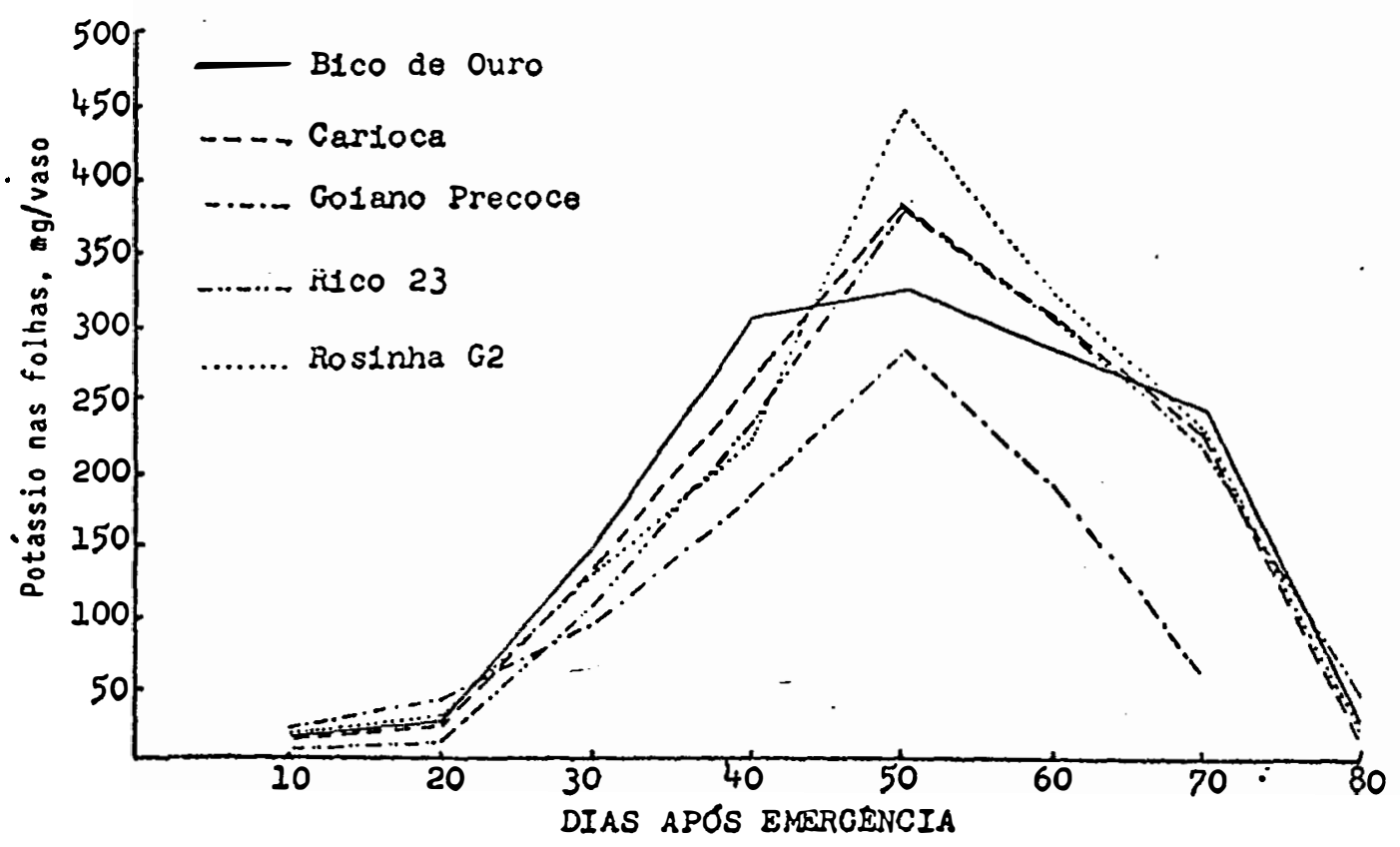

FIGURA 37. Acúmulo de potássio nas fol has do feijoeiro em $\mathrm{mg} / \mathrm{vaso}$ contendo cada um duas plantas. 


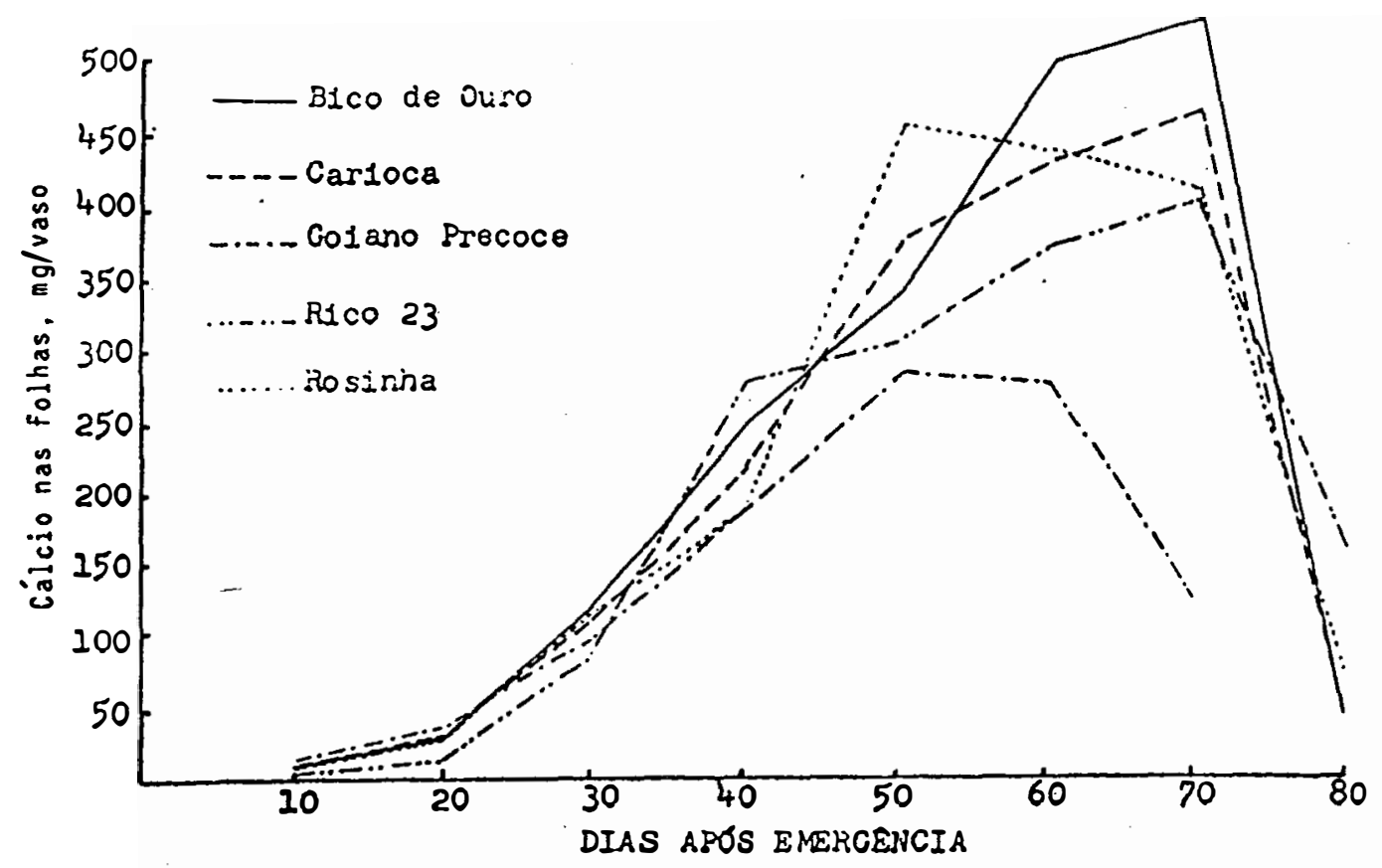

FIGURA 38. Acúmulo de cálcio nas folhas do feijoeiro em $\mathrm{mg} / \mathrm{vaso}$ contendo cada um duas plantas. 
QUADRO 19. Teor de magnésio em percentagem nas folhas do feijoeiro nas diversas idades das plantas.

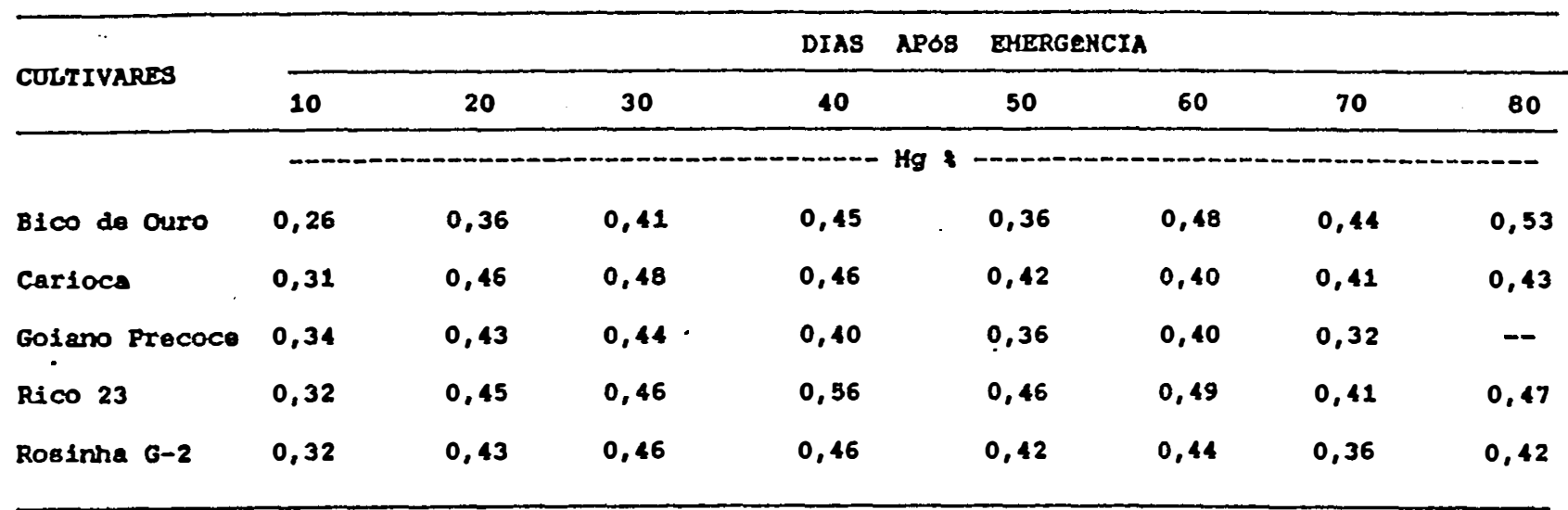

QUADRO 20. Teor em percentagem de nitrogênio, fósforo, potássio, cálcio e magnésio determinados na matéria seca das flores do feijoeiro.

\begin{tabular}{|c|c|c|c|c|c|}
\hline COLTIVARES & $x$ & $\mathbf{P}$ & $\mathbf{K}$ & $\mathrm{Ca}$ & Mg \\
\hline & $\cdots$ & $-\cdots---$ & --1 & -- & $\cdots$ \\
\hline Bico de Ouro & 4,31 & 0,326 & 2,74 & 0,82 & 0,30 \\
\hline Carioca & 4,66 & 0,586 & 2,58 & 1,07 & 0,34 \\
\hline Golano Precoce & 3,89 & 0,538 & 2,76 & 1,01 & 0,34 \\
\hline Rdco 23 & 4,11 & 0,420 & 2,77 & 0,88 & 0,32 \\
\hline Rosinha 62 & 4,34 & 0,586 & 2,66 & 1,06 & 0,37 \\
\hline
\end{tabular}


As flores contribuem muito pouco no acúmulo de nutrientes pelo feijoeiro, tanto pela quantidade de matéria seca produzida quanto pela sua pequena duração. Em relação às demais partes das plantas é de se notar apenas os elevados teores de fósforo nestes órgãos, conforme é mostrado nos quadros 20 e 21 .

Nos quadros 22 a 26 e figuras 40 a 44 são apresentados os valores determinados para nitrogênio, fósforo, potássio, cálcio e magnésio nas vagens e sementes do feijoeiro, quanto ao teor e à quantidade absorvida. Deve-se salientar que nas fases iniciais do desenvolvimento das vagens, nelas se inclui os embriões e as sementes em início de formação, e nas duas últimas amostragens, os valores determinados referem-se somente à palha das vagens.

Quanto ao nitrogênio e fósforo, quadros 22 e 23 e figuras 40 e 41, verifica-se uma queda acentuada em seu teor e na quantidade acumulada pelas vagens, indicando uma movimentação intensa destes elementos para as sementes, ficando a palha com quantidades mínimas. Os teores de potássio, cálcio e magnésio não apresentam variações sensíveis com 0 aumento da idade destas partes, observando-se nas duas últimas amostragens valores semelhantes, indicando serem as palhas das vagens ricas nestes elementos, conforme se observa nos quadros 24,25 e 26 e figuras 42,43 e 44

Os teores e as quantidades de nitrogênio contidos nas sementes dos cultivares testados encontram-se no quadro 27. Desde que formadas, não há grande variação no teor de nitrogênio, 
sendo 0 mesmo ao redor de $3 \%$ para todos os cultivares. Pode-se considerar este como um valor normal tendo-se em vista o valor assumido de $20 \%$ como teor médio de proteína ( $N \% x 6,25)$ nas sementes do feijoeiro, Goiano Precoce mostrou os teores mais elevados de nitrogênio, quase $3,5 \%$ quando da colheita, acima portanto dos demais. As quantidades acumuladas acompanham a produção de matéria seca, sendo Carioca o que mais nitrogênio acumulou, Goiano Precoce o de menor valor, e os demais valores semelhantes, intermediários.

Há um comportamento diferencial quanto ao fósforo nas sementes apresentado pelos cultivares de feijoeiro. Bico de Ouro e Goiano precoce, apresentaram teores mais elevados na primeira amostragem, já que o primeiro mostra redução ao final o ciclo e o segundo não. Exceto para Goiano Precoce, os teores de fósforo nas sementes dos demais cultivares variaram entre 0,249 a $0,290 \%$. Devido ao crescimento da matéria seca todos os cultivares apresentaram maior quantidade no final do ciclo, conforme é mostrado no quadro 28 .

o acúmulo de matéria seca influi diretamente na quantidade de potássio presente nas sementes do feijoeiro, uma vez que não há grande variação em seu teor neste órgão, sendo os dados correspondentes apresentados no quadro 29. 


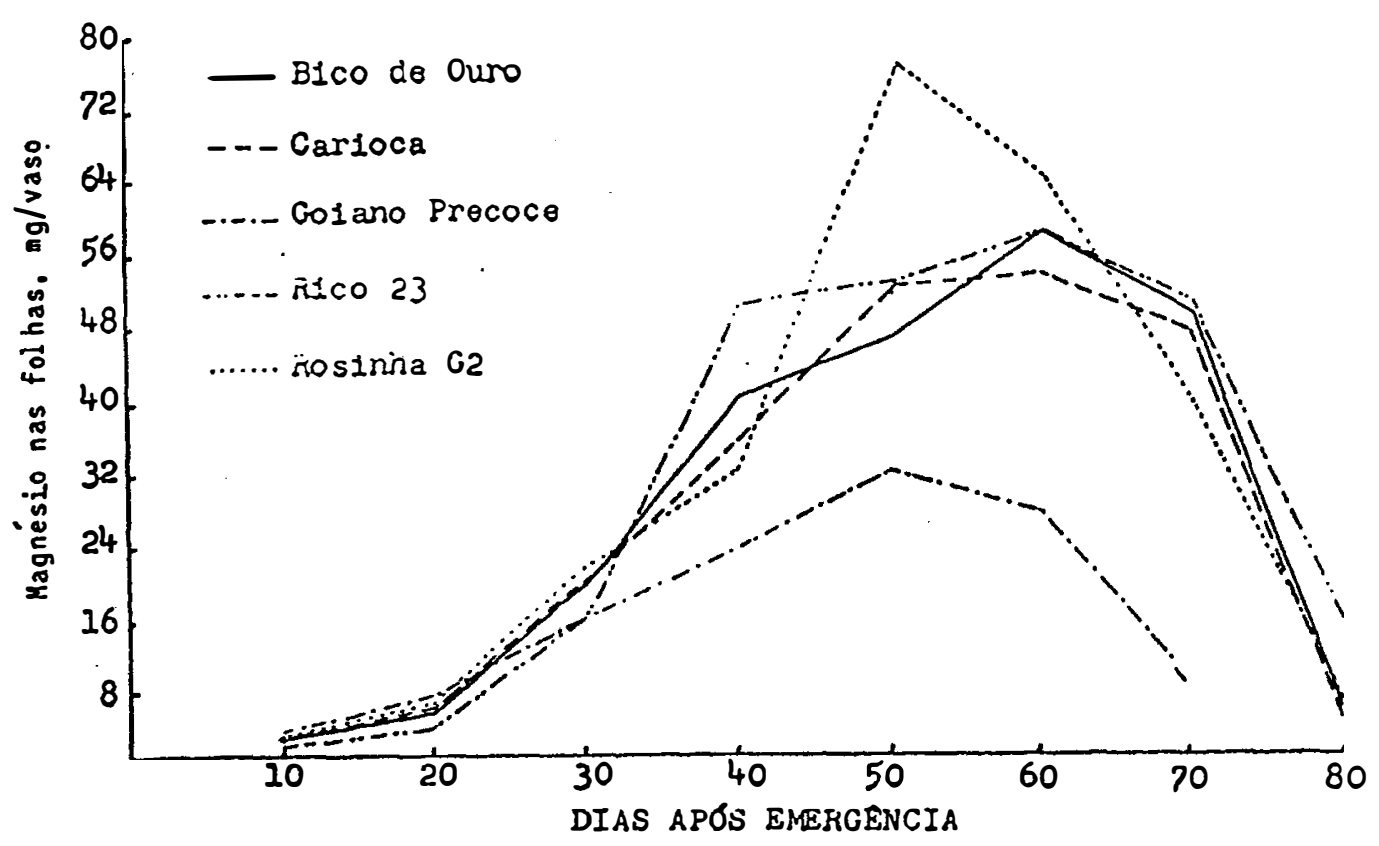

FIGURA 39. Acúmulo de magnésio nas folhas do feijoeiro em mg/vaso contendo cada um duas plantas. 
QUADRO 21. Quantidade de nutrientes acumulado nas flores do feijoeiro, em mg/vaso contendo cada um duas plantas.

\begin{tabular}{|c|c|c|c|c|c|}
\hline CULTIVARES & Nitrogenio & Fosforo & Potássio & Calcio & Kagnosio \\
\hline & \multicolumn{5}{|c|}{ - } \\
\hline Bico de ouro & 22,4 & 1,7 & 13,2 & 4,3 & 1,6 \\
\hline Carioca & 14,4 & 1,8 & 8,0 & 3,3 & 1,1 \\
\hline Goiano Precoce & 7,4 & 1,0 & 5,2 & 1,9 & 0,7 \\
\hline Rico.23 & 18,1 & 1,9 & 12,2 & 3,9 & 1,4 \\
\hline Rosinina G2 & 16,5 & 2,2 & 10,1 & 4,1 & 1,4 \\
\hline
\end{tabular}

QUADRO 22. Teor em percentagem sobre a matéria seca e quantidade de nitrogênio determinados nas vagens do feijoeiro, em $\mathrm{mg} / \mathrm{vaso}$ contendo cada um duas plantas.

\begin{tabular}{|c|c|c|c|c|c|c|c|c|c|c|}
\hline \multirow[t]{2}{*}{ COLTIVARB8 } & \multicolumn{4}{|c|}{ DIAS APGS EMBRGENCIA } & \multirow[b]{2}{*}{80} & \multirow[b]{2}{*}{40} & \multicolumn{3}{|c|}{ DIAS APOS ERERGEHCIA } & \multirow{2}{*}{80} \\
\hline & 40 & 50 & 60 & 70 & & & 50 & 60 & 70 & \\
\hline & \multicolumn{5}{|c|}{ - } & \multicolumn{5}{|c|}{ 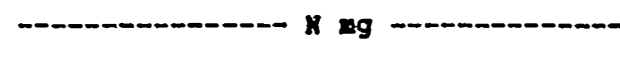 } \\
\hline Bico de ouso & - & 3,10 & 1,72 & 1,23 & 0,61 & -- & 120,0 & 218,8 & 119,7 & 44,0 \\
\hline Cartoce & -- & 3,89 & 2,56 & 1,14 & 0,69 & - & 45,1 & 352,5 & 109,2 & 55,5 \\
\hline Golano Precoce & 4,88 & 3,18 & 1,96 & 0,96 & - & 29,8 & 197,2 & 93,1 & 30,6 & -- \\
\hline Rico 23 & -- & 4,39 & 3,31 & 1,00 & 0,46 & - & 22,8 & 212,5 & 83,4 & 35,6 \\
\hline Rosintha 62 & $-\infty$ & 3,88 & 2,67 & 1,08 & 0,64 & -- & 64,8 & 373,0 & 89,2 & 48,0 \\
\hline
\end{tabular}


QUADRO 23. Teor em percentagem sobre a matéria seca e quantidade de fósforo determinados nas vagens do feijoeiro, em mg/vaso contendo cada um duas plantas.

\begin{tabular}{|c|c|c|c|c|c|c|c|c|c|c|}
\hline \multirow[t]{2}{*}{ CULTIVARE8 } & \multicolumn{5}{|c|}{ DIAS APOS BRERGENCIA } & \multicolumn{5}{|c|}{ DIAS APOS EHERGENCIA } \\
\hline & 40 & 50 & 60 & 70 & 80 & 40 & 50 & 60 & 70 & 80 \\
\hline & \multicolumn{5}{|c|}{ - } & \multicolumn{5}{|c|}{ - } \\
\hline Bico do Ouro & -- & 0,360 & 0,164 & 0,099 & 0,037 & -- & 13,9 & 20,9 & 9,6 & 2,7 \\
\hline Carioce & -- & 0,532 & 0,252 & 0,092 & 0,044 & - & 6,2 & 34,7 & 8,8 & 3,5 \\
\hline Goiano Precoce & 0,556 & 0,590 & 0.151 & 0,061 & - & 3,4 & 36,6 & 7,1 & 2,0 & -- \\
\hline Rico 23 & - & 0,460 & 0,293 & 0,106 & 0,031 & -- & 2,4 & 18,8 & 8,8 & 2,4 \\
\hline Rosinha 62 & - & 0,568 & 0,320 & 0.109 & 0,037 & - & 9,5 & 44,7 & 9,0 & 2,8 \\
\hline
\end{tabular}

QUADRO 24. Teor em percentagem sobre a matéria seca e quantidade de potássio, em mg/vaso contendo cada um duas plantas, determinadas nas vagens do feijoeiro.

\begin{tabular}{|c|c|c|c|c|c|c|c|c|c|c|}
\hline \multirow[t]{2}{*}{ COLTIVARES } & \multicolumn{5}{|c|}{ DIAS APOS ERERGENCIA } & \multicolumn{5}{|c|}{ DIAS APOS EHERGENCIA } \\
\hline & 40 & 50 & 60 & 70 & 80 & 40 & 50 & 60 & 70 & 80 \\
\hline & \multicolumn{5}{|c|}{ 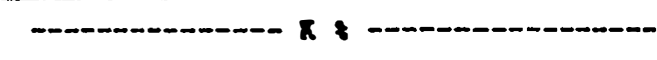 } & \multicolumn{5}{|c|}{ 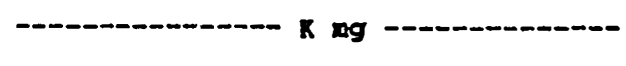 } \\
\hline Bico de ouro & - & 2,10 & 1,54 & 1,75 & 1,99 & - & 81,3 & 195,9 & 170,3 & 143,7 \\
\hline Carioca & -- & 2,13 & 1,61 & 1,39 & 1,62 & -- & 24.7 & 221,7 & 133,2 & 130,4 \\
\hline Golano Precoco & 2,98 & 1,88 & 1,99 & 2,90 & -- & 18,2 & 116,6 & 94,5 & 92,5 & - \\
\hline Rico 23 & -- & 2,91 & 2,25 & 1,53 & 2,38 & - & 15,1 & 144,5 & 127,6 & 184,2 \\
\hline Rosinha 02 & - & 2,13 & 1,51 & 1,36 & 1,48 & -- & 35,5 & 210,9 & 112,3 & 111,0 \\
\hline
\end{tabular}




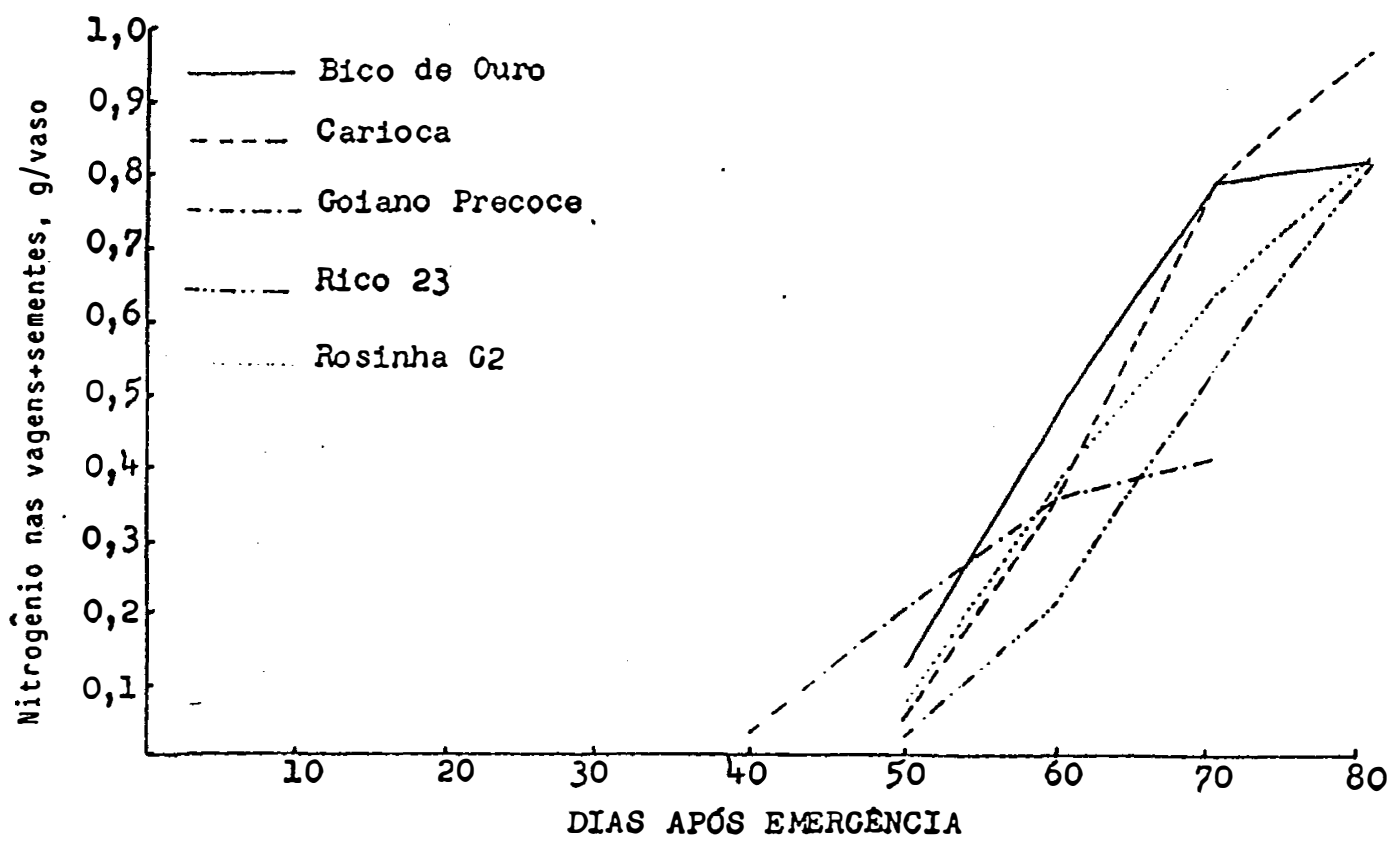

FIGURA 40. Acúmulo de nitrogênio nas partes reprodutivas (vagens + sementes) em g/vaso contendo cada um duas plantas. 


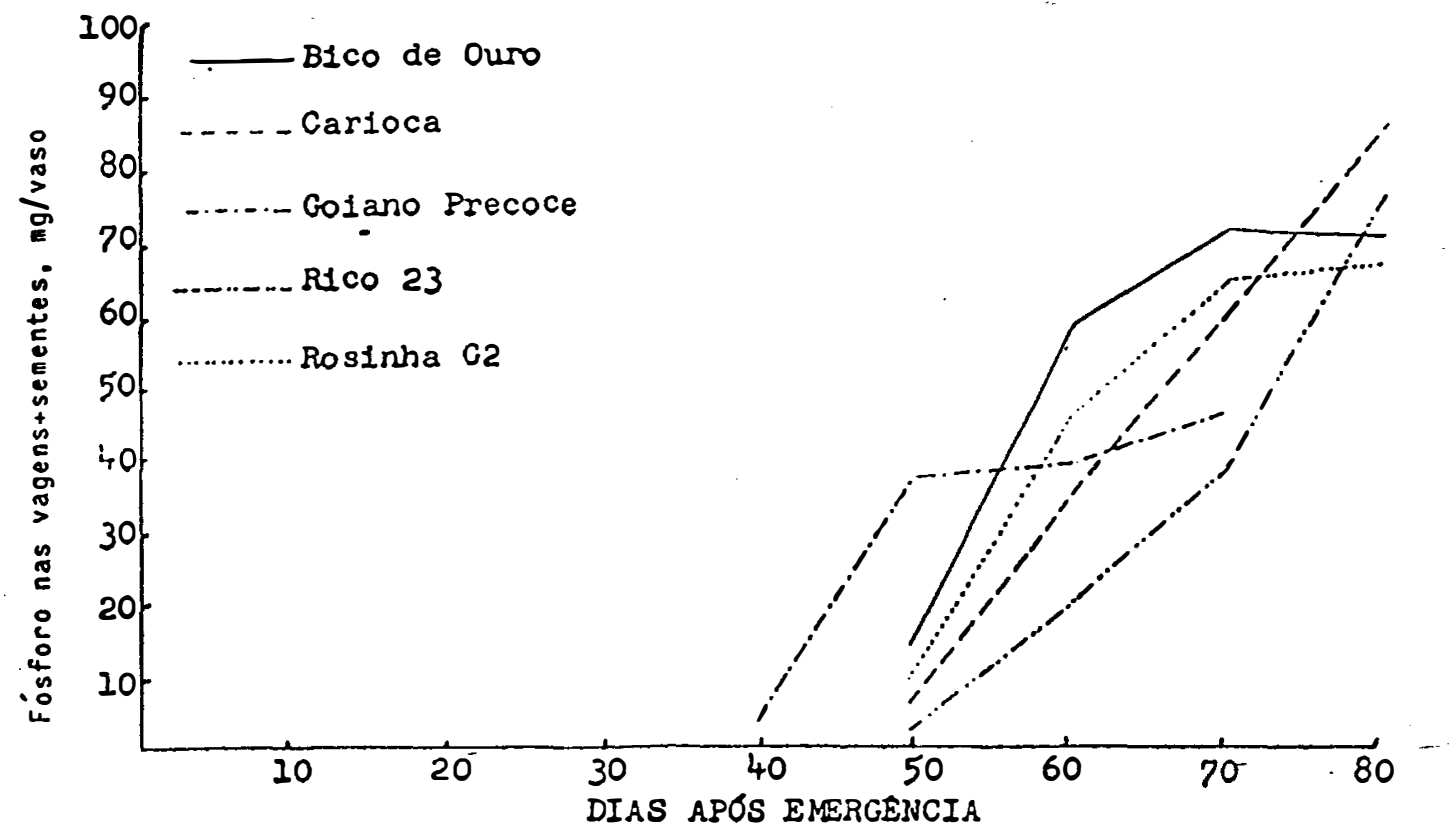

FIGURA 41. Acúmulo de fósforo nas partes reprodutivas (vagens + sementes) em mg/vaso contendo cada. um duas plantas. 
QUADRO 25. Teor em percentagem sobre a matéria seca e quantidade de cálcio, em mg/vaso, contendo cada um duas plantas, determinadas nas vagens de feijoeiro.

\begin{tabular}{|c|c|c|c|c|c|c|c|c|c|c|}
\hline \multirow[t]{2}{*}{ CULTIVAREB } & \multicolumn{4}{|c|}{ DIAS APOB EMRRGENCIA } & 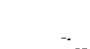 & \multicolumn{5}{|c|}{ DIAS APOS ERERGENCIA } \\
\hline & 40 & 50 & 60 & 70 & 80 & 40 & 50 & 60 & 70 & 80 \\
\hline & \multicolumn{5}{|c|}{ 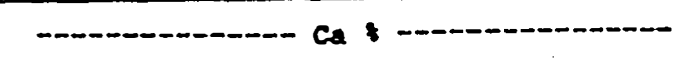 } & \multicolumn{5}{|c|}{ - } \\
\hline Bico de Ouro & -- & 0,95 & 0,68 & 0,66 & 0,65 & -- & 36,8 & 86,5 & 64,2 & 46,4 \\
\hline Carioca & - & 1,68 & 0,73 & 0,57 & 0,67 & -- & 19,5 & 100,5 & 54,6 & 53,9 \\
\hline Goiano Precoce & 1,11 & 0,75 & 0,88 & 0,99 & -- & 6,8 & 46,5 & 41,8 & 31,6 & - \\
\hline Rico 23 & -- & 1,09 & 0,79 & 0,58 & 0,64 & -- & 5,7 & 50,7 & 48,4 & 49,5 \\
\hline Rosinhs 62 & -- & 1,08 & 0,65 & 0,71 & 0,65 & -- & 18,0 & 90,8 & 58,7 & 48,8 \\
\hline
\end{tabular}

QUADRO 26. Teor de porcentagem sobre a matéria seca e quantidade de magnésio em mg/vaso, contendo cada um duas plantas, determinadas nas vagens do feijoeiro.

\begin{tabular}{|c|c|c|c|c|c|c|c|c|c|c|}
\hline \multirow[t]{2}{*}{ CULTIVARBB } & \multicolumn{5}{|c|}{ DIAS APOS EAERGENCIA } & \multicolumn{5}{|c|}{ DIAS APOS ERERGEHCIA } \\
\hline & 40 & 50 & 60 & 70 & 80 & 40 & 50 & 60 & 70 & 80 \\
\hline & \multicolumn{5}{|c|}{ - } & \multicolumn{5}{|c|}{ 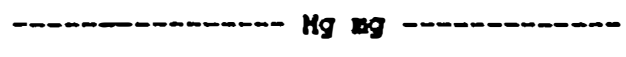 } \\
\hline Bico de ouro & - & 0,31 & 0,25 & 0,26 & 0,28 & -- & 22,0 & 31,8 & 25,3 & 20,2 \\
\hline Carioce & $\rightarrow$ & 0,41 & 0,29 & 0,27 & 0,30 & -- & 4,8 & 39,9 & 25,9 & 24,1 \\
\hline Golano Precoco & 0,33 & 0,24 & 0,32 & 0,41 & - & 2,0 & 14,9 & 15,2 & 13,1 & -- \\
\hline Rico 23 & $-\infty$ & 0,35 & 0,31 & 0,31 & 0,34 & - & 1,8 & 19,9 & 25,9 & 26,3 \\
\hline Rosinina 62 & -- & 0,37 & 0,30 & 0,36 & 0,37 & -- & 6,2 & 41,9 & 29,7 & 27,8 \\
\hline
\end{tabular}




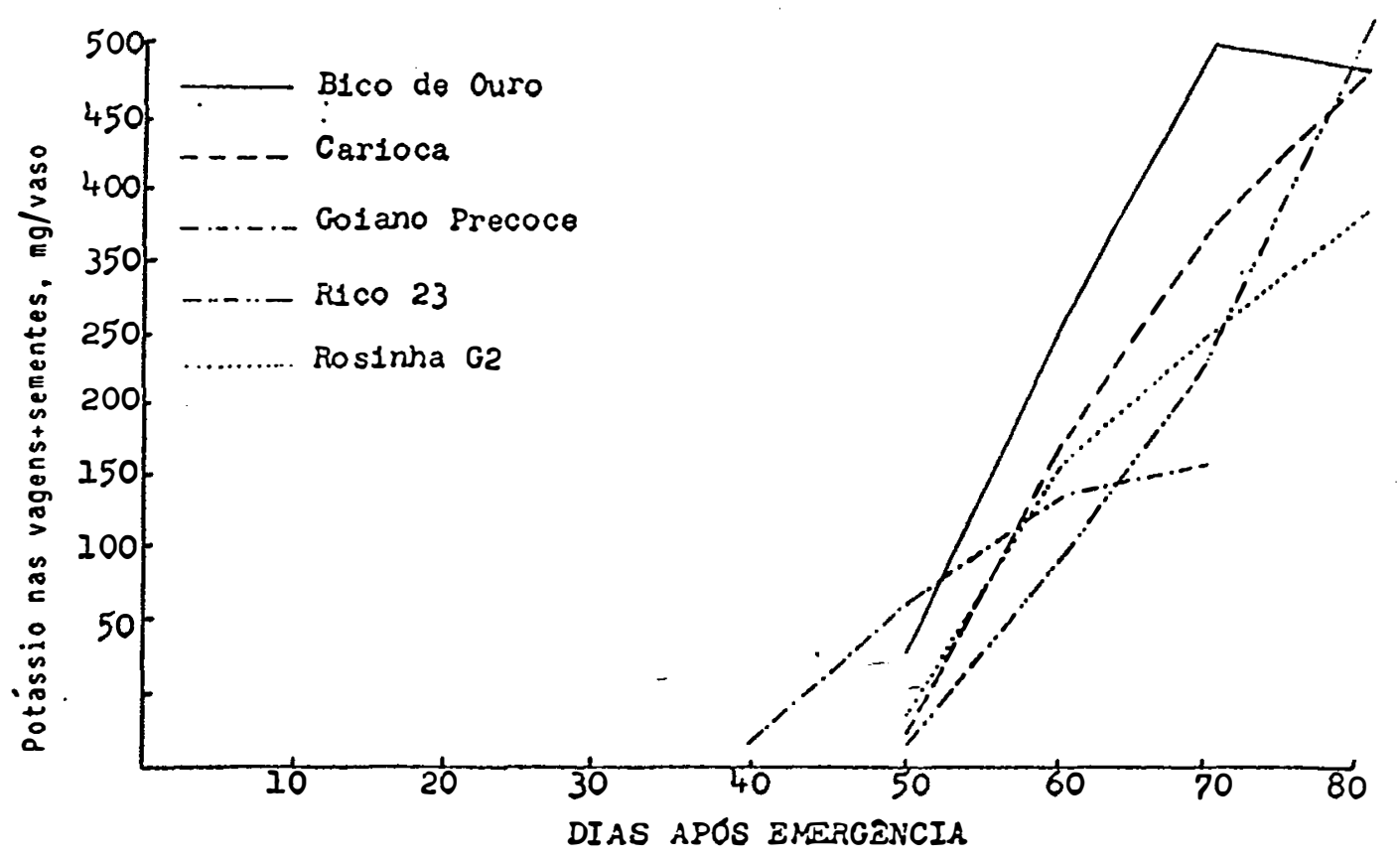

FIGURA 42. Acúmulo de potássio nas partes reprodutivas (vagens + sementes) em $\mathrm{mg} /$ vaso contendo cada um duas plantas. 


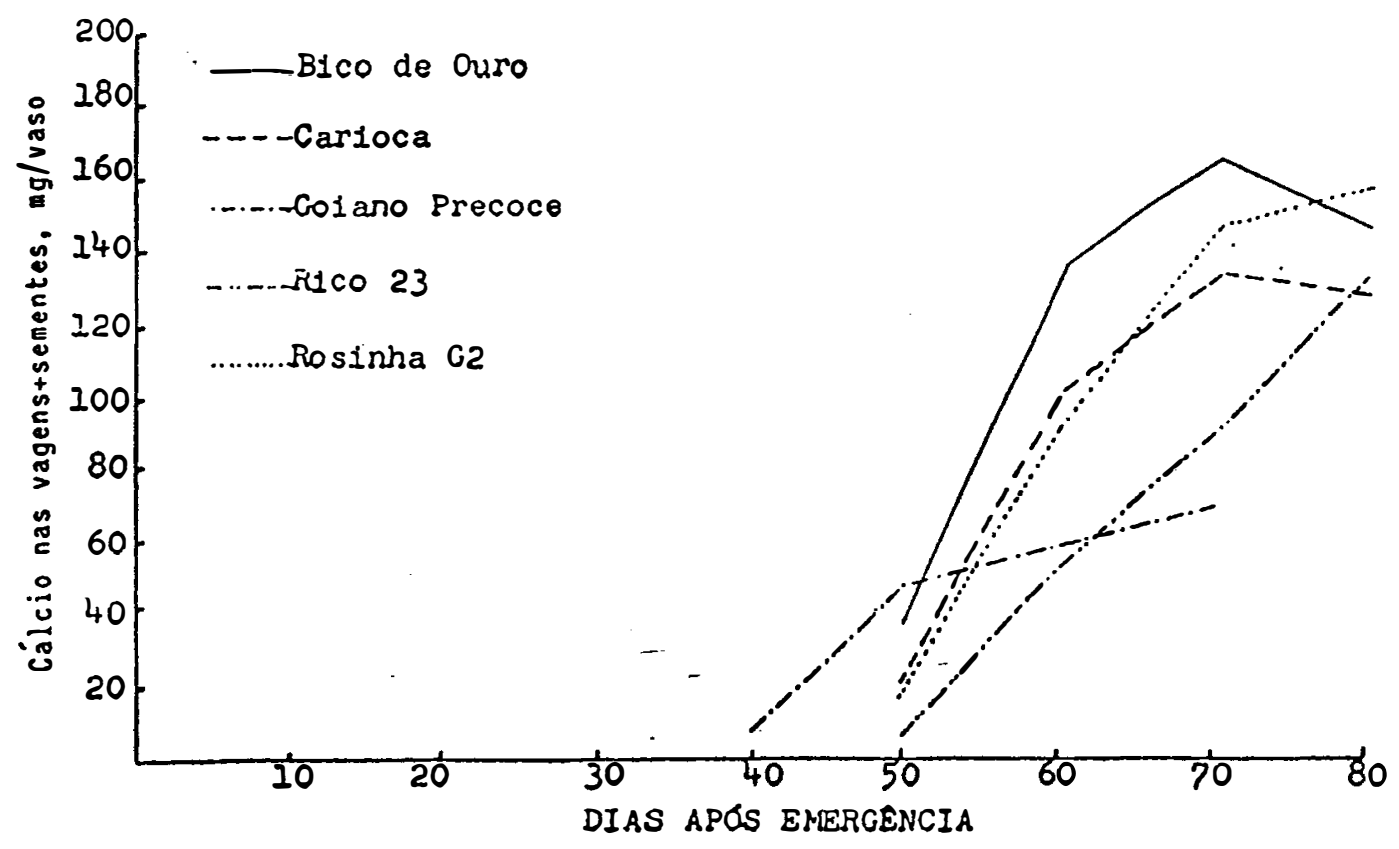

FIGURA 43. Acúmulo de cálcio nas partes reprodutivas (vagens + sementes) em $\mathrm{mg} / v a s o$ contendo cada um duas plantas. 


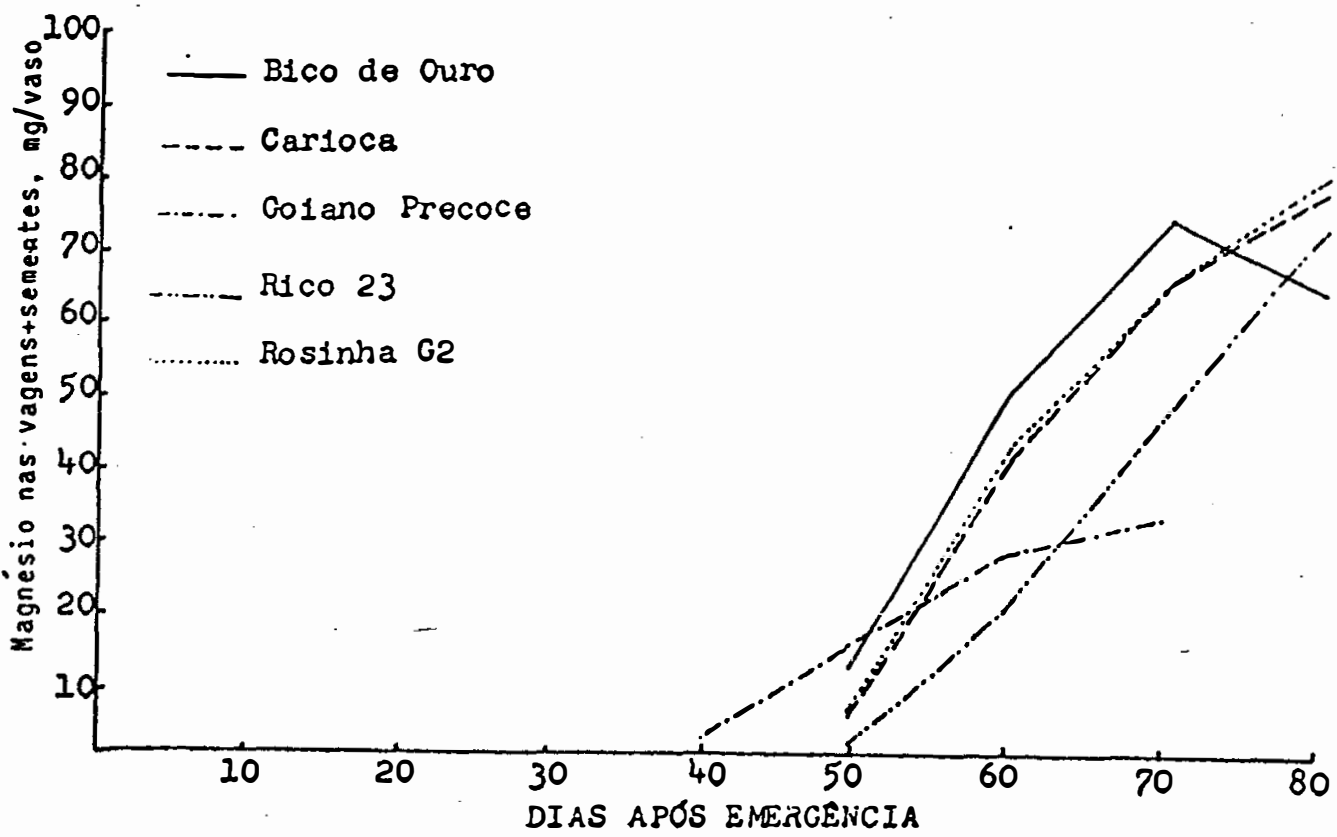

FIGURA 44. Acúmulo de magnésio nas partes reprodutivas (vagens + sementes) em mg/vaso contendo cada um duas plantas. 
QUADRO 27. Teor em percentagem da matéria seca e quantidade de nitrogênio em $\mathrm{mg} / \mathrm{vaso}$, contendo cada um duas plantas, determinadas nas sementes de feijoeiro.

\begin{tabular}{|c|c|c|c|c|c|c|}
\hline \multirow[t]{2}{*}{ CULTIVARES } & \multicolumn{3}{|c|}{ DIAB APOS ERERENCIA } & \multicolumn{3}{|c|}{ DIAS APOS ERERGENCIA } \\
\hline & 60 & 70 & 80 & 60 & 70 & 80 \\
\hline & \multicolumn{3}{|c|}{ - } & \multicolumn{3}{|c|}{ - - $-\cdots-\cdots$} \\
\hline Bico de Ouro & 3,09 & 2,77 & 2,88 & 266,1 & 661,8 & 774,7 \\
\hline Carioca & -- & 2,99 & 3,24 & -- & 677,8 & 909,5 \\
\hline Goiano Precoce & 3,84 & 3,45 & -- & 262,7 & 376,1 & -- \\
\hline Rico 23 & - & 2,98 & 2,91 & - & 445,2 & 781,3 \\
\hline Rosinina G2 & -- & 2,94 & 3,18 & -- & 537,4 & 775,3 \\
\hline
\end{tabular}

QUADRO 28. Teor em percentagem sobre a matéria seca e quantidade de fósforo em mg/vaso, contendo cada um duas plantas, determinadas nas sementes de feijoeiro.

\begin{tabular}{|c|c|c|c|c|c|c|}
\hline \multirow[t]{2}{*}{ CULTIVARES } & \multicolumn{3}{|c|}{ DIAB APOS EMRRGENCIA } & \multicolumn{3}{|c|}{ DIAS APOS ERERGEHCIA } \\
\hline & $60^{-}$ & 70 & 80 & 60 & 70 & 80 \\
\hline & \multicolumn{3}{|c|}{ 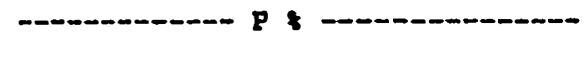 } & \multicolumn{3}{|c|}{ 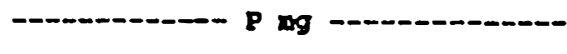 } \\
\hline Bico do ouro & 0,428 & 0,258 & 0,249 & 36,9 & 61,6 & 67,0 \\
\hline Carioca & -- & 0,222 & 0,290 & -- & 50,3 & 81,4 \\
\hline Goiano Prococo & 0,484 & 0,408 & -- & 33,1 & 44,5 & -- \\
\hline Rico 23 & - & 0,188 & 0,275 & -- & 28,1 & 73,8 \\
\hline Rosinha 62 & -- & 0,300 & 0,261 & -- & 54,8 & 66,4 \\
\hline
\end{tabular}


QUADRO 29. Teor em percentagem sobre a matéria seca e quantidade de potássio em $\mathrm{mg} / \mathrm{vaso}$, contendo cada um duas plantas, determinadas nas sementes de feijoeiro.

\begin{tabular}{|c|c|c|c|c|c|c|}
\hline \multirow[t]{2}{*}{ CULTIVARES } & \multicolumn{3}{|c|}{ DIAS APOS EMERGENCIA } & \multicolumn{3}{|c|}{ DIAS APOS EARRGEHCIA } \\
\hline & 60 & 70 & 80 & 60 & 70 & 80 \\
\hline & \multicolumn{6}{|c|}{ 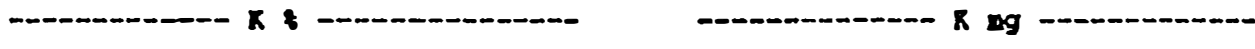 } \\
\hline Bico de Ouro & 1,41 & 1,37 & 1,25 & 121,4 & 327,3 & 336,3 \\
\hline Carioca & -- & 1,05 & 1,25 & -- & 238,0 & 350,9 \\
\hline Golano Precoce & 1,33 & 1,11 & -- & 91,0 & 121,0 & - \\
\hline Rico 23 & -- & 1,02 & 1,23 & -- & 152,4 & 330,3 \\
\hline Rosinha 62 & - & 1,00 & 1,12 & -- & 182,7 & 273,1 \\
\hline
\end{tabular}

QUADRO 30. Teor em percentagem sobre a matéria seca e quantidade de cálcio em mg/vaso, contendo cada um duas plantas, determinadas nas sementes do feijoeiro.

\begin{tabular}{|c|c|c|c|c|c|c|}
\hline \multirow[t]{2}{*}{ CULTIVARES } & \multicolumn{3}{|c|}{ DIAS APO8 EHERGENCIA } & \multicolumn{3}{|c|}{ DIAS APOB ERERGEKCIA } \\
\hline & 60 & 70 & 80 & 60 & 70 & 80 \\
\hline & \multicolumn{6}{|c|}{ - } \\
\hline Bico do Ouro & 0,56 & 0,42 & 0,36 & 48,2 & 100,3 & 96,8 \\
\hline Carioca & - & 0,34 & 0,26 & -- & 77,2 & 72,9 \\
\hline Goiano Precoce & 0,21 & 0,34 & - & 14,4 & 37,1 & - \\
\hline Rico 23 & -- & 0,26 & 0,30 & - & 38,8 & 80,6 \\
\hline Rosinha 02 & -- & 0,47 & 0,44 & -- & 85,9 & 107,3 \\
\hline
\end{tabular}


Quanto ao cálcio nas sementes, quadro 30, apesar da variação no teor em relação ao estágio de desenvolvimento ser ampla, os cultivares não se comportam da mesma maneira. Bico de Ouro, Carioca e Rico 23, apresentam os teores menores no final do ciclo, Rosinha G2 mostrou maior teor e acúmulo, mesmo tendo produzido menos sementes que os demais de mesmo ciclo.

Da mesma maneira que em relação ao cálcio, o magnésio nas sementes, quadro 31, apresenta pequenas variações segundo à idade dás plantas e cultivares. Bico de ouro apresenta redução no teor e na quantidade de magnésio na última amostragem, e os demais acréscimos. Entre cultivares são mínimas as diferenças exceto para acúmulo em Goiano Precoce, que em função da matéria seca produzida contém aproximadamente a metade do magnésio que os demais cultivares.

Nos quadros 32 a 36 é mostrada a quantidade total de nitrogênio, fósforo, potássio, cálcio e magnésio acumulada pelas plantas de feijoeiro nas diversas idades amostradas.

Os cultivares Carioca e Bico de Ouro acumularam mais nitrogênio que os demais. Goiano Precoce entre 50 a 60 dias e os demais a partir do $60^{\circ}$ dia após a emergência apresentaram as maiores quantidades. Exceto para o Rico 23, os demais cultivares apresentaram menores quantidades no final do ciclo, indicando perda de nitrogênio devido à redução na matéria seca, conforme pode ser observado no quadro 32. 
QUADRO 31. Teor em percentagem sobre a matéria seca e quantidade de magnésio em mg/vaso, contendo cada um duas plantas, determinadas nas sementes do feijoeiro.

\begin{tabular}{|c|c|c|c|c|c|c|}
\hline \multirow[t]{2}{*}{ COLTIVARES } & \multicolumn{3}{|c|}{ DIAS APOS ERIRRGENCIA } & \multicolumn{3}{|c|}{ DIAS APOS EMERGEMCIA } \\
\hline & 60 & 70 & 80 & 60 & 70 & 80 \\
\hline & \multicolumn{3}{|c|}{ - } & \multicolumn{3}{|c|}{ 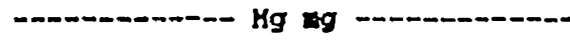 } \\
\hline Bico de Ouro & 0,21 & 0,20 & 0,16 & 18,1 & 47,8 & 43,0 \\
\hline Carioca & -- & 0,17 & 0,19 & -- & 38,5 & 53,3 \\
\hline Goiano Precoce & 0,18 & 0,18 & - & 12,3 & 19,6 & -- \\
\hline Rico 23 & -- & 0,14 & 0,17 & $-\infty$ & 20,9 & 45,6 \\
\hline Rosinhs G2 & -- & 0,19 & 0,21 & -- & 34,7 & 51,2 \\
\hline
\end{tabular}

QUADRO 32. Quantidade total de nitrogênio absorvida pelo feijoeiro nas diversas idades das plantas, em mg/vaso contendo cada um duas plantas.

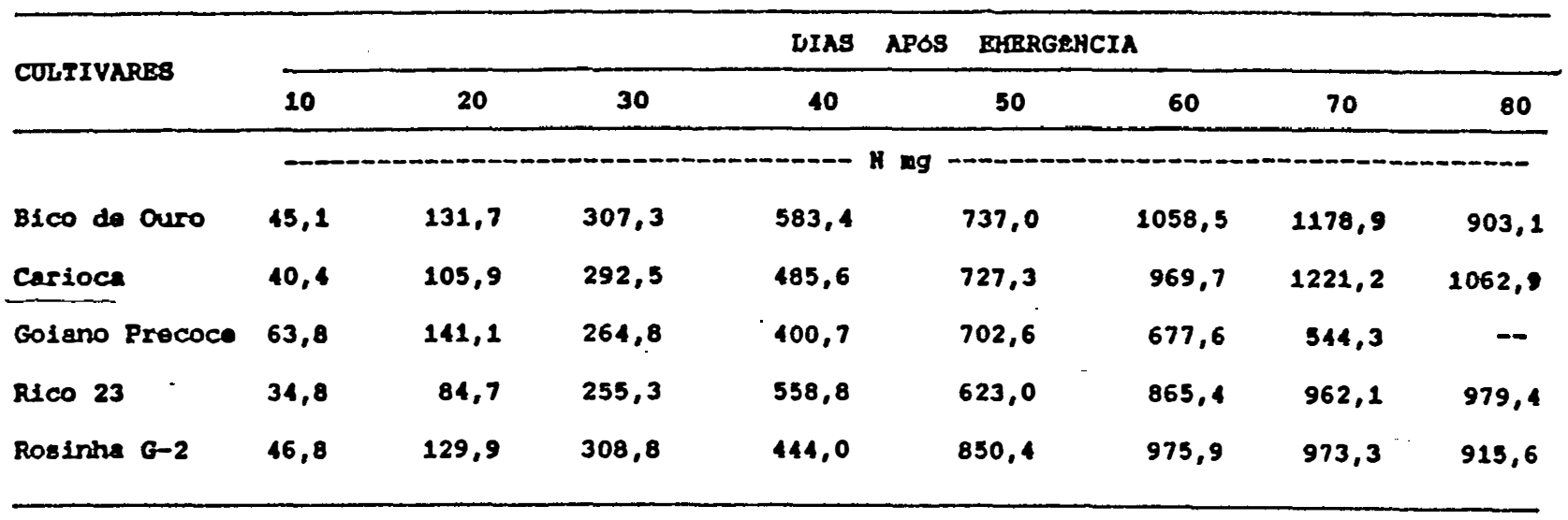


No quadro 33 são apresentados os valores obtidos para acúmulo de fósforo. As maiores quantidades foram observadas no final do ciclo, e há pequena redução para o cultivar Goiano Precoce. Já os cultivares Rosinha G2 e Bico de Ouro apresentaram queda mais acentuada. De maneira geral o fósforo absorvido em sua maior parte se concentra nas sementes, havendo então acentuada exportação do mesmo em relação ao total absorvido.

As tendências de acúmulo do potássio pelos cultivares de feijoeiro são apresentadas no quadro 34 . Bico de Ouro e Carioca apresentam maiores valores aos 70 dias após a emergência, Goiano Precoce aos 50, Rico 23 aos 80 e Rosinha G2 aos 60. Exceto Rico 23, os demais apresentam uma redução no final do ciclo, acompanhando a queda de produção de matéria seca.

Quantidade razoável do cálcio absorvido pelo feijoeiro, quadro 35, não é exportada, tendo se em vista as reduções observadas na última amostragem, ao final do ciclo das plantas, indicando que $\circ$ mesmo se acumula principalmente nas folhas, que caem quando da maturação das plantas.

Quanto ao magnésio, quadro 35 , observa-se semelhante tendência anterior, porém em menor intensidade visto ser este elemento absorvido em menores quantidades que o cálcio.

A máxima absorção de nutrientes pelos cultivares em dados transformados em $\mathrm{kg} / \mathrm{ha}$, considerando-se população ideal de plantas é apresentada no quadro 37. Nitrogênio, potássio, cálcio, magnésio e fósforo é a ordem de grandeza decrescente de acúmulo de 
QUADRO 33. Quantidade total de fósforo absorvida pelo feijoeiro nas diversas idades das plantas, em mg/vaso contendo cada um duas plantas.

\begin{tabular}{lcccccccc}
\hline \multirow{2}{*}{ COLTIVARBs } & \multicolumn{7}{c}{ DIAS } & \multicolumn{7}{c}{ APOS } & EMERGENCIA \\
\cline { 2 - 8 } & 10 & 20 & 30 & 40 & 50 & 60 & 70 & 80 \\
\hline \multirow{2}{*}{ Bico de Ouro } & 2,2 & 3,7 & 18,2 & 34,2 & 62,8 & 98,1 & 100,5 & 79,0 \\
Carioca & 1,3 & 2,4 & 17,8 & 35,2 & 60,9 & 79,8 & 93,9 & 94,6 \\
Goiano Precoco & 2,0 & 3,0 & 10,7 & 19,4 & 63,4 & 57,8 & 56,7 & - \\
Rico 23 & 1,4 & 1,8 & 12,5 & 41,7 & 65,6 & 72,2 & 73,0 & 90,2 \\
Rosinha 6-2 & 2,0 & 3,2 & 16,5 & 28,7 & 76,1 & 89,6 & 90,9 & 73,8 \\
\hline
\end{tabular}

QUADRO 34. Quantidade total de potássio absorvida pelo feijoeiro nas diversas idades das plantas, em mg/vaso contendo cada um duas plantas.

\begin{tabular}{|c|c|c|c|c|c|c|c|c|c|}
\hline \multirow{2}{*}{ CULTIVARES } & & \multicolumn{2}{|c|}{ DIAB APOS } & \multicolumn{2}{|c|}{3 EAERGENCIA } & \multirow[b]{2}{*}{70} & \multirow[b]{2}{*}{80} \\
\hline & 10 & 20 & 30 & 40 & & 50 & 60 & & \\
\hline & $\cdots$ & $\cdots-\cdots$ & $m-\infty$ & $\cdots$ & K & 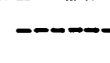 & & & $=$ \\
\hline Bico de Ouro & 22,5 & 38,8 & 217,9 & 407,4 & & 517,1 & 699,4 & 818,9 & 569,2 \\
\hline Carioca & 18,5 & 31,7 & 181,0 & 329,9 & & 498,8 & 626,4 & 679,5 & 559,8 \\
\hline Golano Precoco & 26,2 & 48,9 & 139,8 & 261,8 & & 464,3 & 422,8 & 338,7 & $-\infty$ \\
\hline$R i c 023$ & 12,4 & 17,6 & 163,7 & 359,3 & & 505,9 & 548,1 & 591,0 & 657,9 \\
\hline Rosinha C-2 & 22,1 & 41,1 & 187,1 & 286,0 & - & 595,1 & 616,5 & 594,2 & 458,7 \\
\hline
\end{tabular}


QUADRO 35. Quantidade total de cálcio absorvida pelo feijoeiro nas diversas idades das plantas, em mg/vaso contendo cada um duas plantas.

\begin{tabular}{|c|c|c|c|c|c|c|c|c|c|}
\hline \multirow{2}{*}{ CULTIVAREB } & \multicolumn{4}{|r|}{ DIAS } & APOB & ERERGENCIA & $\therefore$ & \multirow[b]{2}{*}{70} & \multirow[b]{2}{*}{80} \\
\hline & 10 & 20 & 30 & 40 & & 50 & 60 & & \\
\hline Bico de ouro & 13,5 & 36,3 & 152,9 & 314,9 & & 455,3 & 710,9 & 762,9 & 249,4 \\
\hline Carioca & 11,8 & 38,1 & 137,4 & 264,1 & & 465,9 & 623,0 & 679,3 & 260,7 \\
\hline Golano Precoce & 18,0 & 47,7 & 124,4 & 234,9 & & 388,8 & 369,8 & 235,3 & -- \\
\hline$R i c \infty 23$ & 9,2 & 25,9 & $121,1^{\circ}$ & 364,4 & & 398,6 & 505,3 & 572,9 & 384,6 \\
\hline Rosinhs G-2 & 13,8 & 38,9 & 147.7 & 229,6 & & 540,0 & 590,9 & 621,2 & 286,8 \\
\hline
\end{tabular}

QUADRO 36. Quantidade total de magnésio absorvida pelo feijoeiro nas diversas idades das plantas em $\mathrm{mg} / \mathrm{vaso}$ contendo cada um duas plantas.

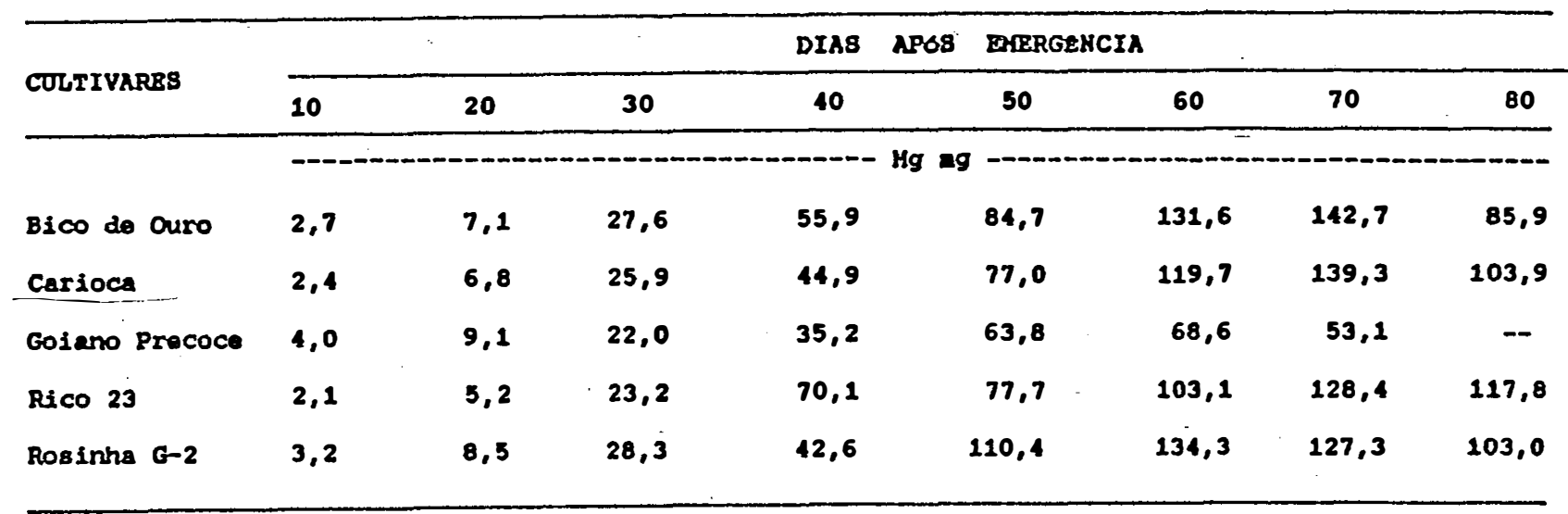


QUADRO 37 . Quantidade máxima de nutrientes absorvida pelos cultivares de feijoeiro testados, em $\mathrm{kg} / \mathrm{ha}$.

\begin{tabular}{lccccc}
\hline CULTIVARBS & KITROGENIO & BOBFORO & POIABSIO & CALCIO & HAGKESIO \\
\hline & $-117,9$ & 10,0 & 81,9 & 76,3 & 14,3 \\
Bico de Ouro & 122,1 & 9,5 & 68,0 & 67,9 & 13,9 \\
Cariocs & 70,3 & 6,3 & 46,4 & 38,9 & 6,9 \\
Goiano Precoce & 97,9 & 9,0 & 65,8 & 57,3 & 12,8 \\
Rico 23. & 97,6 & 9,1 & 61,7 & 62,1 & 13,4 \\
Rosinhs G2 & & & & & \\
\hline
\end{tabular}

QUADRO 38. Acúmulo total de nutrientes pela planta de feijoeiro em $\mathrm{kg} / \mathrm{ha}$, na época da colheita.

\begin{tabular}{|c|c|c|c|c|c|}
\hline CULTIVARES & MITROGEHIO & FOSFORO & POTAssio & Cxucio & MAGNESIO \\
\hline & -n- & $\cdots$ & ha - - & $\cdots$ & --.- \\
\hline Bicó de Ouro & 90,31 & 7,90 & $56,92^{-}$ & 24,94 & 8,59 \\
\hline Carioce & 106,29 & 9,46 & 55,98 & 26,07 & 10,39 \\
\hline Goiano Precoce & 54,43 & 5,67 & 33,87 & 23,53 & 3,31 \\
\hline Rico 23 & 97,94 & 9,02 & 65.79 & 38,46 & 11,78 \\
\hline Rosinha 62 & 91,56 & 7,38 & 45,87 & 28,68 & 10,30 \\
\hline
\end{tabular}


elementos, para todos os cultivares. Exceto para nitrogênio, o cultivar Bico de ouro foi o que apresentou os maiores valores, seguido de perto pelo cultivar Carioca. Os menores valores são observados para Goiano precoce, enquanto que Rico 23 e Rosinha G-2 apresentaram dados intermediários e semelhantes entre si.

Para produções significativamente menores, HAAG et al. (1967) encontraram valores praticamente dobrados de absorção para nitrogênio, fósforo, potássio e cálcio, e triplicados para o magnésio, independentemente do cultivar comparado, exceto para Goiano Precoce, onde estes valores foram maiores ainda. Já os dados mostrados por COBRA NETTO (1967) apresentam similaridade com os do quadro 37 .

Quando da colheita do feijoeiro, encontram-se presentes na planta, em praticamente todos os casos, menores quantidades de nutrientes que o máximo absorvido tendo-se em vista a perda de matéria seca causada pela queda das folhas e fenecimento do sistema radicular. Conforme pode ser observado no quadro 38, ao final do ciclo das plantas, o nitrogênio é o nutriente presente em maiores quantidades, seguido pelo potássio. Quanto ao cálcio há uma queda acentuada, e pouca diferença para o magnésio e fósforo.

No quadro 39 são apresentados os valores estimados em $\mathrm{kg} / \mathrm{ha}$ de nutrientes extraídos pelas sementes de feijoeiro, em função da produção de sementes apontada e de uma população ideal de 200.000 plantas por hectare. Pouco do cálcio absorvido é exportado pelas sementes, e pequena é a variação entre cultivares 
QUADRO 39. Extração de nutrientes, em $\mathrm{kg} / \mathrm{ha}$, pelas sementes do feijoeiro.

\begin{tabular}{lccccc}
\hline CULTIVARES & HITROGEHIO & FOSFORO & POTABSIO & CALCIO & HAGKESIO \\
\hline \multirow{2}{*}{ Bico de Ouro } & 77,47 & 6,70 & 33,63 & 9,68 & 4,30 \\
Cariocs & 90,95 & 8,14 & 35,09 & 7,29 & 5,33 \\
Goisno Prococe & 37,61 & 4,45 & 12,10 & 3,71 & 1,96 \\
Rico 23 & 78,13 & 7,38 & 33,03 & 8,06 & 4,56 \\
Rosinha 62 & 77,53 & 6,64 & 27,31 & 10,73 & 5,12 \\
\hline
\end{tabular}

QUADRO 40. Relação entre a quantidade máxima de nutrientes absorvida e a presente no momento da colheita.

\begin{tabular}{|c|c|c|c|c|c|}
\hline COLTIVARES & NITROGENIO & FOBFORO & POTABsIo & CxICro & MAGHESIO \\
\hline & - & - & --- & -- & - \\
\hline Bico de ouro & 76,6 & 78,6 & 69,5 & 32,7 & 60,2 \\
\hline Carioce & 87,0 & 100,0 & 82,4 & 38,4 & 74,6 \\
\hline Goiano Precoco & 77.5 & 89,4 & 73,0 & 60,5 & 77,4 \\
\hline Rico 23 & 100,0 & 100,0 & 100,0 & 67,1 & 91,8 \\
\hline Rosinha 02 & 93,8 & 81,2 & 74,4 & 46,2 & 76,7 \\
\hline
\end{tabular}


exceto Goiano precoce que apresentou os menores valores de produção de matéria seca de grãos. O nitrogênio e o fósforo acumulam-se preferencialmente nas sementes, sendo o cultivar Carioca o que apresentou os valores mais elevados. Bico de Ouro, Rico 23 e Rosinha G2 mostraram grande semelhança nas quantidade determinadas. Esta exportação de nutrientes foi semelhante aos valores observados por COBRA NETO (1967), HAAG et al. (1967) e FEITOSA et al. (1980) para nitrogênio, fósforo e cálcio e corresponde à metade daquela apontada para potássio e magnésio pelos dois primeiros autores.

Tomando-se como base a máxima quantidade de nutrientes absorvida e aquela presente nas plantas no momento da colheita foram estabelecidos os valores percentuais constantes no quadro 46. O cultivar Rico 23 mostrou ciclo vital mais prolongado que os demais, apontado por um acúmulo de nitrogênio, fósforo e potássio até o final do ciclo. O cultivar Carioca mostrou a mesma tendência quanto ao nutriente fósforo. Este caráter deve ser observado quando das comparações entre cultivares ou da avaliação de acúmulo pela espécie, uma vez que a fase fisiológica interna define a tendência do acúmulo, isto é se termina antes ou se prolonga até o final do ciclo das plantas. Pela observação dos referidos dados verificam-se diferenças no comportamento entre cultivares no que diz respeito à absorção e acúmulo de nutrientes. Bico de Ouro e Carioca mostram uma acentuada perda de cálcio, seguida posteriormente por Rosinha G2. Os cultivares Goiano Precoce e Rico 23 mantiveram até a colheita elevada quantidade de cálcio (aproximadamente $60 \%$ do total absorvido), provavelmente 
devido a um menor índice de colheita e portanto maior manutenção do arcabouço da planta.

No quadro 41 são apontados as relações percentuais entre as quantidades de nutrientes presentes na planta no momento da colheita com aquelas exportadas pelas sementes. Através dele pode-se verificar um comportamento diferencial entre cultivares sendo que Goiano Precoce exporta relativamente menos nitrogênio que os demais. Entre 80 e $85 \%$ do nitrogênio e do fósforo presente na planta no momento da colheita estão nas sementes, o mesmo ocorrendo com 50 a $60 \%$ do potássio, 20 a 38\% do cálcio e 40 a 50\% do magnésio. Pelo exame do mesmo quadro verifica-se que o cultivar Goiano Precoce mostrou valores inferiores aos anteriormente indicados, sugerindo uma menor eficiência no aproveitamento dos nutrientes.

Relacionando-se as quantidades de nutrientes presentes nas sementes com os valores máximos de acúmulo para cinco cultivares, foi montado o quadro 42, nele observou-se que Rico 23 e Rosinha G2 mostraram valores mais elevados para nitrogênio, Carioca para fósforo, Carioca e Rico 23 para potássio, Rosinha G2 para cálcio e Carioca e Rosinha G2 para magnésio, confirmando resultados de AMARAL et al (1980) de que há diferenças sensíveis entre cultivares na sua eficiência de conversão entre nutriente absorvido para nutriente exportado. Apesar de variações entre cultivares deve-se considerar estes dados como mais reproduzíveis 
QUADRO 41. Relação entre a quantidade de nutrientes presentes na época da colheita e a exportada pelas sementes.

\begin{tabular}{|c|c|c|c|c|c|}
\hline CULTIVARBS & MITHOGENIO & FOSFORO & POTABsIo & CALCIO & MAGNEBIO \\
\hline & $\cdots$ & 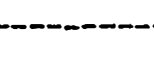 & $-\cdots$ & - & --- \\
\hline Bico de ouro & 85,8 & 84,8 & 59,1 & 38,8 & 50,1 \\
\hline Carioca & 85,6 & 86,1 & 62,7 & 28,0 & 51,3 \\
\hline Coiano Precoce & 69,1 & 78,5 & 35,7 & 15,8 & 36,9 \\
\hline Rico 23 & 79,8 & 81,8 & 50,2 & 20,9 & 38,7 \\
\hline Rosinhe G2 & 84,7 & 90,0 & 59,5 & 37,4 & 49,7 \\
\hline
\end{tabular}

QUADRO 42. Relação entre a quantidade máxima de nutrientes absorvida e a exportada pelas sementes.

\begin{tabular}{|c|c|c|c|c|c|}
\hline COLTIVAREB & MITROGENIO & EOSFORO & P0Ix8810 & CALCIO & MAGHEBIO \\
\hline & - & -m & $\cdots$ & 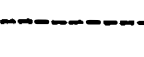 & -..-- \\
\hline Bico de ouro & 65,7 & 66,7 & 11,1 & 12,7 & 30,1 \\
\hline Carioca & 74,5 & 86,1 & 51,6 & 20,7 & 38,3 \\
\hline coiano Precocs & 53,5 & 70,2 & 26,1 & 9,6 & 28,6 \\
\hline Rico 23 & 79,8 & 81,8 & 50,2 & 14,1 & 35,5 \\
\hline Rosinhs G2 & 79,5 & 73,0 & 44,3 & 27,3 & 38,1 \\
\hline
\end{tabular}


em relação aos anteriores, pois pode haver maiores variações devido ao subjetivismo do momento em época de colheita. Observa-se que pouco do cálcio absorvido é exportado pelas sementes, em média dos cultivares menor que 15\% e Goiano Precoce e Carioca ao redor de $10 \%$ Quanto ao magnésio, os valores observados ficaram entre 28 e 38\% aproximadamente, dependendo do cultivar. Nitrogênio, fósforo e potássio apresentam tendência semelhante aos dados relativos ao quadro 41 já discutido, e para os quais as mesmas considerações são válidas. Estes percentuais são bastante semelhantes aos mostrado por GALLO e MIYASAKA (1961) para o termo médio, não considerando-se as variações devidas aos cultivares. Goiano Precoce exportou muito menos nitrogênio e potássio que os demais. Rico 23 e Rosinha G2 exportaram mais nitrogênio, Carioca e Rico 23 mais fósforo-e potássio que os demais. 


\section{CONCLUSÕES}

Nas condições em que se executou este experimento, os resultados obtidos permitem as conclusões seguintes:

1. O cultivar Goiano Precoce produziu significativamente menos matéria seca total e de sementes que os demais cultivares. A menor produção de grãos foi fruto de um menor número de vagens/vaso e de sementes/vagem a despeito de um maior peso das sementes; seu menor índice de colheita contribuiu para esta performance.

2. Os cultivares Bico de Ouro, Carioca e Rico 23 apresentaram pela ordem 66,64 e $62 \%$ de índice de colheita, valores significativamente superiores aos 57 e $50 \%$ apresentados por Rosinha G2 e Goiano Precoce, respectivamente. 
3. Para os cultivares Bico de Ouro, Carioca, Rico 23 e Rosinha G2, comparáveis quanto a ciclo total, apesar de diferenças significativas entre os componentes de produção vagens/vaso, sementes/vagem e peso das sementes não houve diferença significativa na produção de sementes, mostrando efeito de compensação entre estes componentes.

4. O cultivar Bico de Ouro, de ciclo semelhante aos cultivares Carioca, Rico 23 e Rosinha G2 mostrou um florescimento mais compacto e anterior que os demais. O cultivar Rico 23 mostrou a maior intensidade de acúmulo de matéria seca nas sementes entre 70 e 80 dias, e devido a esta característica, crescimento das sementes só no final do ciclo, colheitas antecipadas podem prejudicar muito a produção deste cultivar.

5. Os fluxos de produção de flores, de acúmulo de matéria seca nas sementẹ e as medidas de área folịar específica e massa foliar específica mostram que plantas de ciclo semelhante podem estar em estádios fisiológicos internos distintos, que devem ser considerados nas comparações pontuais em amostragens sistemáticas.

6. O feijoeiro emite um número maior de vagens do que consegue manter e nutrir. O cultivar Bico de Ouro foi o que apresentou inicialmente maior número de vagens, e mostrou um índice de aborto mais acentuado: Rico 23 e Carioca mostraram desde os 
50 dias após a emergência valores muito semelhantes com crescimento entre 50 e 60 dias e posterior redução. Goiano Precoce mostrou valores muito menores que os demais.

7. Carioca foi o cultivar que mostrou a maior produção de sementes estimada em $2.807 \mathrm{~kg} / \mathrm{ha}$, seguido por Bico de Ouro com $2.690 \mathrm{~kg} / \mathrm{ha}$, Rico $23 \mathrm{com} 2.625 \mathrm{~kg} / \mathrm{ha}$, Rosinha G2 com $2.436 \mathrm{~kg} / \mathrm{ha}$ todos sem diferença significativa entre si, e finalmente Goiano Precoce com $1.090 \mathrm{~kg} / \mathrm{ha}$.

8. Os maiores valores de quantidade máxima de nutrientes absorvida foram observados para Carioca e Bico de Ouro. Foram absorvidos 122 e $118 \mathrm{~kg} / \mathrm{ha}$ de nitrogênio, 68 e $82 \mathrm{~kg} / \mathrm{ha}$ de potássio, 68 e $76 \mathrm{~kg} / \mathrm{ha}$ de cálcio, 14 e 14 kg/ha de magnésio e 9,5 e $10 \mathrm{~kg} / \mathrm{ha}$ de fósforo, respectivamente.

9. Nitrogênio, potássio, cálcio, magnésio e fósforo foi a ordem decrescente de quantidade máxima de nutrientes absorvida, exceto para Carioca e Rosinha G2 que absorveram potássio tanto quanto cálcio.

10. O cultivar Rico 23 mostrou os maiores valores percentuais entre máximo valor absorvido e nutrientes presentes no momento da colheita, mostrando um acúmulo bastante tardio em relação aos demais cultivares. 
11. Apesar de diferenças entre cultivares, e excetuando-se o cultivar Goiano precoce, entre 65 e $80 \%$ do nitrogênio e do fósforo absorvidos são exportados pelas sementes, entre 40 e 50\% do potássio, 30 a 38\% do magnésio e 12 a 17\% do cálcio. 


\section{LITERATURA CITADA}

ADAMS, M.W., 1972. Dry Bean Breeding in the United States. "In" Anais do I Simpósio Brasileiro de Feijão, Universidade Federal de Viçosa, Minas Gerais. Vol. I, pag. 201-208.

ALVIM, R. \& ALVIM, P. de T. 1969. Efeito da densidade de plantio no aproveitamento da energia luminosa pelo milho (Zea mays) e pelo feijão (Phaseolus vulgaris), em culturas exclusivas e consorciadas. Turrialba, 19:389-393.

AMARAL, F.A.L.; REZENDE, H.E.C. de; BRASIL SOBRINHO, M.O.C. \& MALAVOLTA, E. 1980. Exigências de nitrogênio, fósforo e potássio de alguns cultivares de feijoeiro (Phaseolus vulgaris L.). Anais da Escola Superior de Agricultura "Luiz de Queiróz". Piracicaba, $37: 223-39$. 
AMBLER, J.E. \& BROWM, J.C. 1969. Cause of differential susceptibility to zinc deficiency in two varieties of navy beans (Phaseolus vulgaris L.) Agronomy Journal 61:41-43.

ANTONIW, L.D. e SPRENT, J.I. 1978. Growth and nitrogen fixation of (Phaseolus vulgaris L.) at two irradiances. I. Growth. Annals of Botany, London 42:329-397.

APPLE, S.B. \& BUTTS, J.S. 1953. Soil temperature studies. The effect of soil temperature and phosphorus on growth and $\mathrm{P}$ uptake by pole beans. Proceedings of the American Society for Horticultural Science 61:325-332.

ARAUJO, G.A.A. 1983. Crescimento de plantas e conversão da energia solar em sistemas de cultivos associados e exclusivos de milho e feijão. Tese de Doutorado - Universidade Federal de Viçosa, Viçosa, MG. 129 p.

BATAGLIA, O.C., FURLANI, A.M.C., TEIXEIRA, J.P.F., FURLANI, P.R. e GALLO, J.R. 1983. Métodos de Análise química de plantas. Campinas, Instituto Agronômico, 48p. (Boletim Técnico 78).

BERNARDO, S., GALVÃO, J.D., GUERINI, H. e CARVALHO, J.B. 1970 Efeito de níveis de água no solo sobre a produção do feijoeiro. Seiva, Universidade Federal de Viçosa, Viçosa, M.G. 30:7-13. 
BERNSTEIN, L. \& AYRES, A.D. 1951. Salt Tolerance of six varieties of green beans. Proceedings of the American Society of Horticultural Science. 57:245-248.

BIDDULPH, O., CORY, R. e BIDDULPH, S. 1959. Translocation of calcium in the bean plant. Plant Physiology 34:512-519.

BIDDULPH, O. NAKAYAMA, F.S. e CORY, R. 1961. Transpiration stream ascension of calcium. Plant Physiology 36:429-436.

BIENKLEY, A.M. 1932. The amount of blosson and pod drop on six varieties of garden beans. Proceedings of the American Society for Horticultural Science. 29:489-492.

BOAWN, L.C., RASMUSSEN, P.E. \& BROWN, J.W. 1969. Relationship between tissue zinc levels and maturity period of field beans. Agronomy Journal 61:49-51.

BRANDES, D. 1971. Análise de crescimento do feijoeiro (Phaseolus vulgaris L.). Efeito da densidade e da época de plantio. Universidade Federal de Viçosa, Viçosa, MG. Tese de Mestrado.

BROWER, R. 1962. Distribuition of dry matter in the plant. Netherlands Journal of Agricultural Science. Wageningen 10:361375 . 
CABALLERO, S.V., LIBARDI, P.L., REICHARDT, K., MATSUI, E., VICTORIA, R.L. 1985. Utilização do fertilizante nitrogenado aplicado a uma cultura de feijão. Pesquisa Agropecuária Brasileira. Brasilia, DF, 20 (9):1031-1040.

CAROLUS, R.L. 1938. Effect of certain ions used singly and in combination on the growth and potassium, calcium and magnesium absorption of the bean plant. Plant Physiology 13:349-369.

COBRA NETTO, A. 1967. Absorção e deficiência dos macronutrientes pelo feijoeiro (Phaseolus vulgaris L.; var. Roxinho). ESA. "Luiz de Queiróz", Piracicaba-SP. Tese de Doutoramento.

COBRA NETTO, A., ACORSI, W.R. \& MALAVOLTA, E. 1971. Estudos sobre a nutrição mineral do feijoeiro (Phaseolus vulgaris L., var. Roxinho). Anais da Escola Superior de Agricultura "Luiz de Queiroz". Piracicaba-SP. Vol.XXVIII: 257-274.

COYNE, D.P. 1968. Effect of temperature on pod set of varieties of (Phaseolus vulgaris L.) Annual Report of the Bean Improvement Cooperative. Michigan, 11:16-17.

COYNE, D.P. 1969. Correlation of yield components in beans. Annual Report of the Bean Improvement Cooperative. Michigan, 12:13-15. 
DALE, J.E. 1965. Leaf growth in (Phaseolus vulgaris L.), II Temperature effects and light factors. Annals of Botany 29:293308 .

DAVIS, J.F. 1945. The effect of some environmental factors on the set of pods and yield of white pea beans. Journal of Agricultural Research 70:237-248 .

DUARTE, R.A. \& ADAMS, M.W. 1972. A path coefficient analysis of some yield component interrelations in field beans (Phaseolus vulgaris L.). Crop Science 12:579-582.

EHRLER, W.L., LANGE, A.H. \& HAMNER, K.C. 1958. The effect of nutrient balance on the uptake-transport of calcium and phosphorus by bean plants. Proceedings of the American Society for Horticultural Science 72:365-369.

EMERSON, R.A. 1916. A genetic study of plant height in Phaseolus vulgaris. Nebraska Agricultural Experimental Station Research Bulletin $n^{\circ} 7$.

FEITosA, C.T., RONZELli, P.J., ALMEIDA, L. D’A. de, VEIGA, A.A. HIROCE, R. \& JORGE, J.P.N. 1980. Adubação NP para o feijoeiro (Phaseolus vulgaris L.) na presença e na ausência de calcáreo. Revista Brasileira de Ciência do Solo. 4(3):156-159. 
FOY, C.D., ARMIGER, W.H., FLEMING, A.L. \& ZAUMEYER, W.I. 1967. Differential tolerance of dry bean, snap bean and lima bean varieties to an acid soil high in exchangeable aluminium. Agronomy Journal 59:561-563.

GALLO, J.R. \& MIYASAKA, S. 1961. Composição química do feijoeiro e absorção de elementos nutritivos, do florescimento à maturação. Bragantia 20:867-884.

GAUCH, H.G. \& WADLEIGH, C.H. 1945. Effect of high concentrations of sodium, calcium, chloride and sulfate on ionic absorption by bean plants. Soil Science 59:139-153.

GREENE, D.W \& BUKOWAK, M.J. 1968. Redistribution of calcium in Phaseolus vulgaris L. Proceedings of the American Society for Horticultural Science. 93:368-378.

HAAG, H.P., MALAVOLTA, E. \& BLANCO, H.G. 1967. Absorção de nutrientes pelá cultura do feijoeiro. Bragantia 26:381-392.

HAAG, W.L., ADAMS, M.W. \& PINCHINAT, A.M. 1971. Differential response among bean varieties to nitrogen and phosphorus. Annual Report of the Bean Improvement Cooperative. Michigan, 14:38-40. 
HENDRIX, J.E. 1967. The effect of $\mathrm{pH}$ on the uptake and accumulation of phosphate and sulphate ions by bean plants. American Journal of Botany 54:560-564.

HESTER, J.B., SHELTON, F.A. \& ISAACS Jr., R.L. 1951. The rate and amount of plant nutrient absorbed by various vegetables. Proceedings of the American Society for Horticultural Science. $57: 249-251$.

HIROCE, R., GALLO, J.R. \& MASCARENHAS, H.A.A. 1970. Análise foliar em feijoeiro. II - Diagnose da adubação fosfatada. Bragantia 29 $\left(\right.$ nota $\left.n^{\circ} 2\right):$ VII-XII.

HIROCE, R. GALLO, J.R. \& MIYASAKA, S. 1969, Análise foliar de feijoeiro. I - Nutrição nitrogenada e potássica. Bragantia 28 $\left(\right.$ nota $\left.n^{\circ} 1\right):$ I-VIII.

HORNER, G.M. \& MOJTEHEDI, M. 1970. Yield of grain legumes as affected by irrigation and fertilizer regimes. Agronomy Journal $62: 449-450$

HOWE, E.W. \& RHOADES, H.F. 1961. Irrigation of Great Northern field beans in western Nebraska. Nebraska Agricultural Experimental Station Bulletin $n^{\circ} 459$. 
IZHAR, S. \& WALLACE, D.H. 1967a. Effect of night temperature on photosynthesis of Phaseolus vulgaris L. Crop. Science 7:546-547.

IZHAR, S. \& WALLACE, D.H. 1967b. Studies of the physiological basis for yield differences. III Genetic variation in photosynthetic efficiency of Phaseolus vulgaris L. Crop Science 7:457-460.

JANES, B.E. 1948. The effect of varying amounts of irrigation on the composition of two varieties of snap beans. Proceedings of the American Society for Horticultural Science 51:457-462.

JONES, L.H. 1971. Adaptive responses to temperature in dwarf french beans Phaseolus vulgaris L. Annals of Botany 35:581-596.

KATTAN, A.A. \& FLEMING, J.W. 1956. Effect of irrigation at specific stages of development on yield quality, growth and composition of snap beans. Proceedings of the American Society for Horticultural Science 68:329-342.

LAMBERTH, V.N. 1950. Some factors influencing pod set and yield of the Iima beans. Missouri Agricultural Experimental station Research Bulletin $\mathrm{n}^{\circ} 466$.

LANGE, A.H. , EHRLER, W.L. \& HAMNER, H. 1959. Effect of environment on the uptake-transport of calcium and phosphorus by bean 
plants. Proceedings of the American Society for Horticultural Science $73: 349-354$.

LOPES, N.F. 1988. Adaptabilidade fisiológica ao consórcio, in Cultura do Feijoeiro - Fatores que afetam a produtividade. M.J. de O.Zimmermann, M.Rocha e T.Yamada, eds. Associação Brasileira para Pesquisa da Potassa e do Fosfato. Piracicaba, SP. 589 p.

LOPES, N.F., OLIVA, M.A., MELGES, E., FURTADO, M.H., FREITAS, J.G. 1983. Crescimento, morfologia, partição de assimilados e produção de matéria seca do feijão (Phaseolus vulgaris L.) submetido a três níveis de densidade do fluxo radiante. Revista Ceres, Viçosa, $30(172): 451-462$.

LOPES, N.F., OLIVA, M.A., FREITAS, J.G., MELGES, E., BELTRÃO, N.E.M. 1982. Análise de crescimento e conversão da energia solar em feijoeiro (Phaseolus vulgaris L.) submetido a três níveis de densidade do fluxo radiante. Revista Ceres, Viçosa, $29(166): 586-606$

LUNIN, J., GALLATIN, M.R. \& BATCHELDER, A.R. 1964a. Interactive effects of basic saturation and exchangeable sodium on the growth and cation composition of beans. Soil Science 97:25-33.

LUNIN, J., GALLATIN, M.R. \& BATCHELDER, A.R. 1964b. Interactive effects of soil fertility and salinity on the growth and 
composition of beans. American Society for Horticultural Science. Proceedings. 85:350-360.

MACK,H.J. \& SINGH, J.N. 1969. Effect of high temperature on yield and carbohydrate composition of bush snap bean. Journal of the American Society for Horticultural Science 94:60-62.

MACKAY, D.C. \& LEEFE, J.S. 1962. Optimum leaf levels of nitrogen, phosphorus and potassium in sweet corn and snap beans. Canadian Journal of Plant Science 42:238-246.

MAFRA, R.C. 1972. Absorção e distribuição de nutrientes minerais no feijoeiro (Phaseolus vulgaris L.). Efeitos da densidade e da época de plantio. Tese de mestrado. Universidade Federal de Viçosa - Minas Gerais.

MAFRA, R.C., VIEIRA, C., BRAGA, J.M., SIQUEIRA, C., BRANDES, D. 1974. Efeitos da população de plantas e da época de plantio no crescimento do feijoeiro (Phaseolus vulgaris L.) IV. Absorção de nutrientes. Experientiae, Viçosa, 17 (9) 217-239.

MAGALHÃES, A.C. \& MONTOJOS, J.C. 1971. Effect of solar radiation on the growth parameters and yield of two varieties of common beans (Phaseolus vulgaris L.). Turrialba 21:165-168. 
MAGALHÃES, A.C., MONTOJOS, J.C. \& MIYASAKA, S. 1971 . Effect of dry organic matter on qrowth and yield of beans (Phaseolus vulgaris L.) Experimental Agriculture 7:137-143.

MALAVOLTA, E. 1969. Arroz e Feijão - Grandes exigências. "In" Guia Rural 1968/1969, São Paulo, pg.10-13.

MALAVOLTA, E. 1972. Nutrição e Adubação do Feijoeiro "In" Anais do I Simpósio Brasileiro de Feijão. Universidade Federal de Viçosa. Viçosa, M.G. vol. I. pag. 211-242.

MAURER, A.R., ORMOND, D.P., \& SCOTT, N. 1969. Effect of five soil water regimes on growth and composition of snap beans. Canadian Journal of Plant Science 49:271-278.

MCMASTER, G.M., LEBARON, M.J., COREY, G.L., HOWTHRORN, L.R. \& TOOLE, U.F. 1965. The influence of soil moisture on snap bean seed production. Idaho Agricultural Experimental station Bulletin $n^{\circ} 435$.

MELTON, J.R., ELLIS, B.G. \& DOLL, E.C. 1970. Zinc, phosphorus and lime interactions with yield and zinc uptake by (Phaseolus vulgaris L.) Soil Science Society of America. Proceedings 34:9193. 
MILLAR, A.A. \& GARDNER, W.R. 1972. Effect of the soil and plant water potentials on the dry matter production of snap beans. Agronomy Journal 64:559-562.

MIYASAKA, S. \& ALMEIDA, L.D. de. 1968. Clima e solo para o feijoeiro. Instituto Agronômico do Estado de São Paulo, Seção de Leguminosas, Campinas. Mimeografado, 47 p. $2^{\text {a }}$ Ed.

MIYASAKA, S., CAMARGO, A.P., INFORZATO, R. \& IGUE T. 1966. Efeitos da incorporação ao solo, de diferentes espécies e formas de aplicação de matéria orgânica não decomposta, imediatamente antes do plantio de feijão. Anais de Congresso Pan-Americano de Conservação do Solo, 1 ${ }^{a}$, São Paulo_pg 49-58.

MONTOJOS, J.C. \& MAGALHÃES, A.C. 1971. Growth Analysis of dry beans (Phaseolus vulgaris L. var. Pintado) under varying conditions of solar radiation and nitrogen application. Plant and Soil 35:217223.

MORAIS, J.F.V. 1988. Calagem e adubação. In Cultura do Feijoeiro. Fatores que afetam a produtividade. M.J.O. Zimmermmann, M.Rocha e T.Yamada eds. Associação Brasileira para pesquisa da potassa e do fosfato. Piracicaba, SP, $589 \mathrm{p}$.

OLIVEIRA, I.P., THUNG, M.D.T. 1988. Nutrição Mineral. In Cultura do Feijoeiro - Fatores que afetam a produtividade. 
M.J.O.Zimmermmann, M.Rocha e T.Yamada eds. Associação Brasileira para pesquisa da potassa e do fosfato. Piracicaba, SP, $589 \mathrm{p}$.

POLSON, D.E. \& ADAMS, M.W. 1970. Differential response of navy beans (Phaseolus vulgaris L.) to zinc. I differential growth and elemental composition at excessive $\mathrm{Zn}$ levels. Agronomy Journal $62: 557-560$.

RAIJ, B. van e QUAGGIO, J.A. 1983. Métodos de análise de solo para fins de fertilidade. Campinas, Instituto Agronômico, 31 p. (Boletim Técnico 81).

RAPPAPORT, L. \& CAROLUS, R.L. 1956. Effects of night temperatures at different stages of development on reproduction in the lima bean. Proceedings of the American Society for Horticultural Science. $67: 421-428$.

ROSOLEM, C.A. 1987. Nutrição e Adubação do feijoeiro. Piracicaba, POTAFÓs. Boletim Técnico 8,93p.

SCHELLENBERGER, R.G. \& ADAMS, M.W. 1971. Differential response of two navy bean varieties (Phaseolus vulgaris L.) to zinc. Annual Report of the Bean Improvement Cooperative. 14:56-58. 
SHEA, P.F., GABELMAN, W.H. \& GERLOFF, G.C. 1967. Inheritance of efficiency in potassium utilization in snap beans (Phaseolus vulgaris L.) American Society for Horticultural science. Proceedings 91:286-293.

SINGH, J.N. \& MACK, H.J. 1963. Effects of soil temperature on growth, fruiting and mineral composition of snap beans. American Society for Horticultural Science. Proceedings. 88:378-383 .

SMITH, F.L. \& PRYOR, R.H. 1962. Effects of maximum temperature and age on flowering and seed production in three bean varieties. Hilgardia $33: 669-689$.

SÖNDAHL, M.R., MAGALHÃES, A.C. \& MONTOJOS, J.C. 1971. Efeito da temperatura no crescimento, florescimento e produção em duas variedades de feijão (Phaseolus vulgaris L.). I Simpósio Brasileiro de Feijão, Campinas, (Mimeografado) .

STOBBE, E.H., ORMROD, D.P. \& WOOLEY, C.J. 1966. Blossoning and fruit set patterns in Phaseolus vulgaris L. as influenced by temperature. Canadian Journal of Botany. 44:813-819.

THOMAS, W., MACK, W.B. \& COTON, R.H. 1942. Foliar diagnosis in relation to irrigation. Proceedings of the American Society for Horticultural Science. 40:531-535: 
VIETS, F.G., BOAWN, L.C. \& CRAWFORD, C.L. 1954. Zinc content of beans plants in relation to deficiency simptoms and yield. Plant Physiology $29: 76-79$.

VIGLIERQUIO, D.R. \& WENT, F.W. 1957. Plant Growth under controled conditions. IX. Growth and fruiting of Kentucky wonder bean (Phaseolus vulgaris L.). American Journal of Botany. 44:449-453.

WALLACE, D.H. \& MUNGER, H.M. 1965. Studies of physiological basis for yield differences. I. Growth analysis of six dry beans varieties. Crop Science 5:343-348.

WALLACE, B.H. \& MUNGER, H.M. 1966. Studies of the physiological basis for yield differences. II. Variations in dry matter distribution among aerial organs for several dry bean varieties. Crop Science 6:503-507. 